\title{
Development of web platform for dissemination of design with social impact methodology
}

\author{
Slave Ristomanov
}

Faculty of Mechanical Engineering, Industrial Design, Ss Cyril and Methodius University of Skopje, Skopje, Republic of Macedonia

\begin{abstract}
Citation: Ristomanov S. [Development of web platform for dissemination of design with social impac methodology]. SEE J Archit Des. 2018 Jun 20; 10029 http://dx.doi.org/10.3889/seejad.2018.10033

Keywords: Design with social impact; Ethnographic research; Creative techniques; Creative thinking; Grounded theory; Web design; Web platform Correspondence: Slave Ristomanov. Faculty of Mechanical Engineering, Industrial Design, Ss Cyril and Methodius University of Skopje, Skopje, Republic Macedonia. E-mail: ristomanov_slave@hotmail.com Received: 24-Apr-2019; Revised: 10-Jun-2019; Accepted: 15-Jun-2019; Published: 27-Oct-2019

Copyright: ๑ 2019 Slave Ristomanov. This is an openbuted under the te pre, distribution, and reproduction in any medium, provided the original author and source are credited. Competing Interests: The author has declared that no competing interests exis
\end{abstract}

\begin{abstract}
Since the distant history of mankind, the phenomenon of the social impact of design is noticed. The term design with social impact has appeared in frequent use for the last decade, but the interest of designers for the impact of their works in social change has long been there. The designer's approach has undergone major changes over the years, focusing on the outward appearance of products, their features, usability, versatile customer testing, to the involvement of users in the design process. The main goal of this master's thesis is to study the essence of the approach design with social impact and its importance in today's society, to study the methods that emerge from it and to contribute to the promotion, dissemination and application of the knowledge and experiences from the realized activities of this field in our society. The research emphasized the study of the most modern scientific methods in the field of design, as ethnographic research and grounded theory. In order to clarify and define the essence of this methodology, realized projects from the held workshops within the international project "Design with Social Impact" were presented and analysed. The draw conclusions are presented in the form of guidelines on how it should be applied, what are its advantages, and why its application is useful. As a final result of this research a web platform was created aimed at spreading the idea about the possibilities of the methodology design with social impact in our society as a factor that can affect the social changes, and at the same time as an opportunity to exchange knowledge and experiences of the designers. This paper is expected to promote the methodology of design with social impact in our surroundings in order to contribute to raising awareness about the importance of designers and the creative way of thinking as an important factor for solving numerous problems in contemporary communities and contemporary living.
\end{abstract}




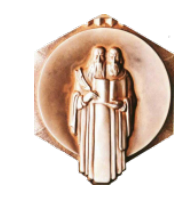

УНИВЕРЗИТЕТ „СВ. КИРИЛ И МЕТОДИЈ“ - СКОПЈЕ

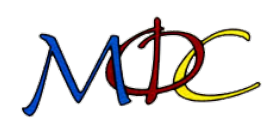

МАШИНСКИ ФАКУЛТЕТ - СКОПЈЕ

ПОСТДИПЛОМСКИ СТУДИИ ПО ИНДУСТРИСКИ ДИЗАЈН И МАРКЕТИНГ

СЛАВЕ РИСТОМАНОВ

Развој на веб платформа за промовирање на методологијата дизајн со општествено влијание

МАГИСТЕРСКА РАБОТА

CKOПJE, 2019 
Ментор:

Проф. д-р Софија Сидоренко

Машински Факултет - Скопје

Членови на комисијата:

Проф. д-р Софија Сидоренко

Машински Факултет - Скопје, ментор

Проф. д-р Татјана Кандикјан

Машински Факултет - Скопје, член

Доц. д-р Ташко Ризов

Машински Факултет - Скопје, член

Дата на одбрана:

Дата на промоција: 


\section{СЛАВЕ РИСТОМАНОВ, дипл. инж. по индустриски дизајн}

\section{Развој на веб платформа за промовирање на методологијата дизајн со општествено влијание}

\section{АПСТРАКТ:}

Уште во далечната историја на човештвото се забележува феноменот за општественото влијание на дизајнот. Терминот дизајн со општествено влијание се појавил во честа употреба дури последнава деценија, но интересот на дизајнерите за влијанието на нивните дела во општествените промени постои одамна. Пристапот на дизајнерите претрпел големи промени со текот на годините, од фокус на надворешниот изглед на производите, нивните функции, употребливоста, разновидните тестирања од корисниците, се до инволвирање на корисниците во дизајн процесот.

Главната цел на овој магистерски труд е да се проучи суштината на пристапот дизајн со општествено влијание $и$ нејзиното значење во денешното општество, да бидат проучени методите што произлегуваат од него и да се придонесе за промовирање, ширење и примена на знаењата и искуствата од реализираните активности од оваа област во нашето општество. При истражувањето беше ставен акцент на проучување на најсовремени научни методи од областа на дизајнот, како етнографско истражување и втемелена теорија.

Со цел да се појасни и дефинира суштината на оваа методологија беа презентирани и анализирани реализирани проекти од одржаните работилници во рамките на меѓународниот проект „Дизајн со општествено влијание“. Извлечените заклучоци се презентирани во вид на насоки за начинот на кој таа треба да се применува, кои се нејзините предности и зошто е корисна нејзината примена.

Како краен резултат на ова истражување е креирана веб платформа која има за цел ширење на идејата за можностите на методологијата дизајн со општествено влијание во нашето општество како фактор кој може да влијае на општествените промени, а истовремено како можност за размена на знаењата и искуствата на дизајнерите. Се очекува со овој труд да се промовира методологијата дизајн со општествено влијание во нашата средина со цел да се даде придонес кон подигање на свеста за значењето на дизајнерите и креативниот начин на размислување како важен фактор за решавање на бројни проблеми во современите заедници и современото живеење.

КлУчни ЗБОРОВИ: дизајн со општествено влијание, етнографско истражување, креативни техники, креативно размислување, втемелена теорија, веб дизајн, веб платформа. 


\section{SLAVE RISTOMANOV, B. Eng. in industrial design}

\section{Development of web platform for dissemination of design with social impact methodology}

\section{ABSTRACT:}

Since the distant history of mankind, the phenomenon of the social impact of design is noticed. The term design with social impact has appeared in frequent use for the last decade, but the interest of designers for the impact of their works in social change has long been there. The designer's approach has undergone major changes over the years, focusing on the outward appearance of products, their features, usability, versatile customer testing, to the involvement of users in the design process. The main goal of this master's thesis is to study the essence of the approach design with social impact and its importance in today's society, to study the methods that emerge from it and to contribute to the promotion, dissemination and application of the knowledge and experiences from the realized activities of this field in our society. The research emphasized the study of the most modern scientific methods in the field of design, as ethnographic research and grounded theory. In order to clarify and define the essence of this methodology, realized projects from the held workshops within the international project "Design with Social Impact" were presented and analyzed. The drawn conclusions are presented in the form of guidelines on how it should be applied, what are its advantages, and why its application is useful. As a final result of this research a web platform was created aimed at spreading the idea about the possibilities of the methodology design with social impact in our society as a factor that can affect the social changes, and at the same time as an opportunity to exchange knowledge and experiences of the designers. This paper is expected to promote the methodology of design with social impact in our surroundings in order to contribute to raising awareness about the importance of designers and the creative way of thinking as an important factor for solving numerous problems in contemporary communities and contemporary living.

KEY WORDS: design with social impact, ethnographic research, creative techniques, creative thinking, grounded theory, web design, web platform. 


\section{СОДРЖИНА}

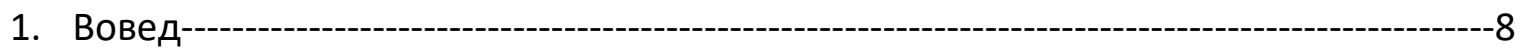

1.1 Цели на магистерската работа-------------------------------------------------------------------8

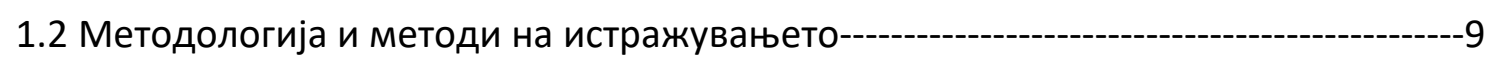

2. Хронолошки развој на дизајн со општествено влијание како методологија------11

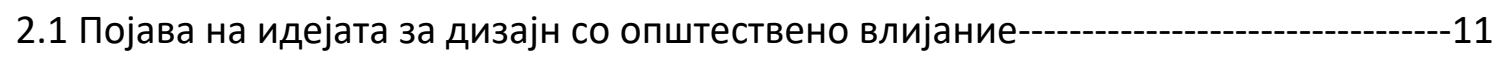

2.2 Пристапи низ историјата кои придонеле во развојот на дизајн со општествено

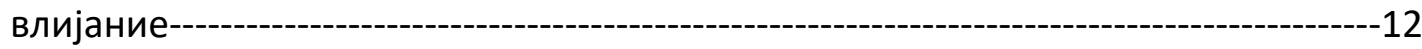

2.2.1 Социјална одржливост-----------------------------------------------------------------13

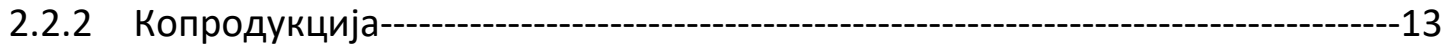

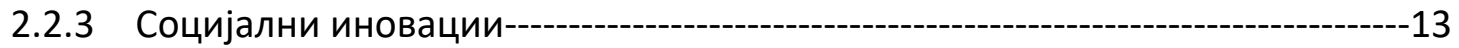

2.2.4 Дизајн за социјални иновации---

2.2.5 Колаборативни услуги-----------------------------------------------------------14

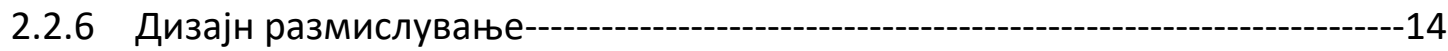

2.2.7 Дизајн со фокус на корисникот--------------------------------------------------14

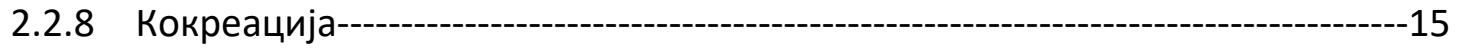

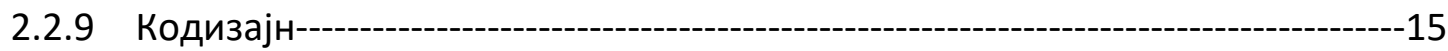

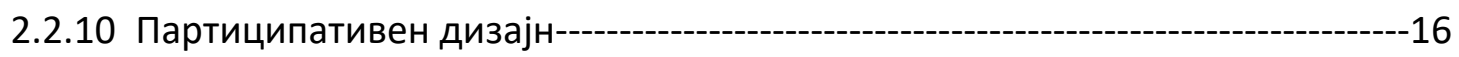

2.2.11 Дизајн со општествено влијание-----------------------------------------------------17

2.3 Споредбена анализа на истражуваните пристапи------

3. Применета методологија на истражување--------------------------------------------20

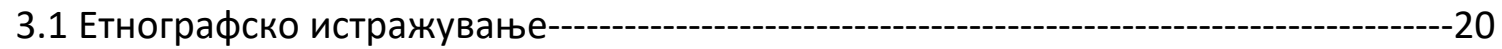

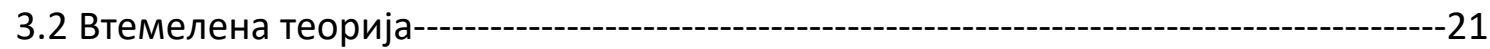

4. Преглед на резултатите и искуствата од реализирани работилници од областа

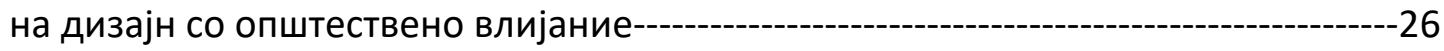

4.1 Работилница „Проекти за Македонија - учење едни од други“, Скопје, мај/јуни

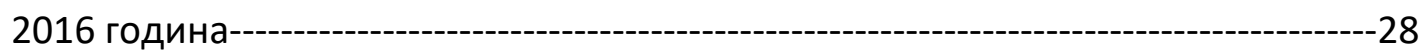

4.2 Работилница „Земјоделство, храна и потрошувачка“, Мачакос, Кенија, април

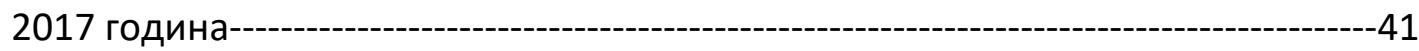

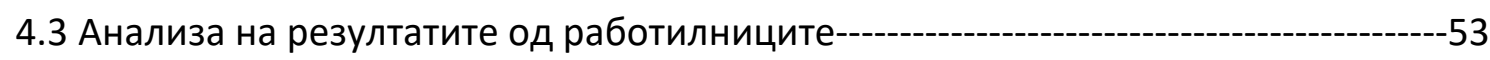

4.3.1 Какви проблеми кај заедниците препознаа студентите-----------------------53 


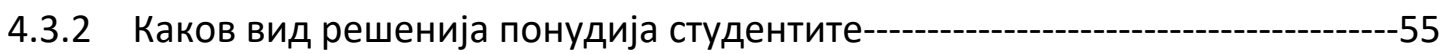

4.3.3 Колку тие решенија беа одговор на однапред поставените очекувања--56

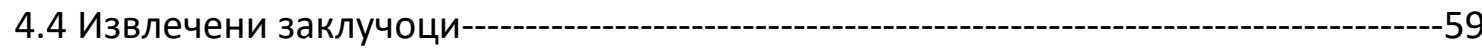

5. Истражување на резултатите од работилниците со примена на видео етнографија и втемелена теорија----_-

5.1 Собирање етнографски материјали на работилниците во Цирих и Скопје------61

5.2 Евалуација и интерпретација на собраниот материјал од етнографскотот

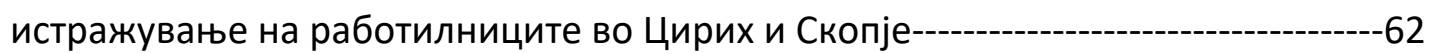

5.3 Анализа на собраниот материјал од етнографскотот истражување на работилниците во Цирих и Скопје---.---

5.4 Собирање етнографски материјали на работилницата во Кенија------------------64

5.5 Систематизација на извлечените заклучоци и знаења од спроведеното етнографско истражување во согласност со т.н. „втемелена теорија“ -----------65

5.6 Споредбена анализа помеѓу регуларен процес на дизајнирање и процес на

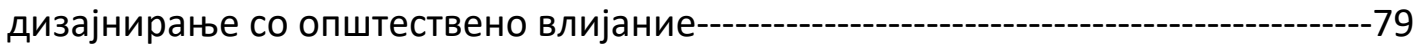

5.7 Како се реализира проект од областа на дизајн со општествено влијание------80

5.8 Придобивки од извршеното истражување--

6. Анализа на состојбите во нашето општество и анализа на можностите за примена на методологијата дизајн со општествено влијание заради нивно

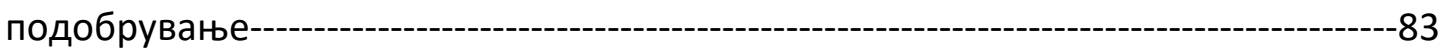

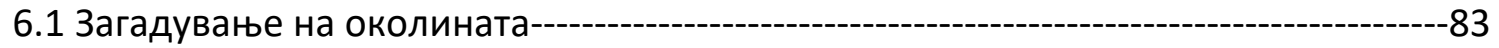

6.2 Политичка состојба-------_-

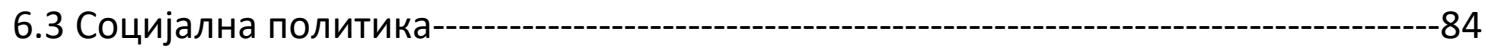

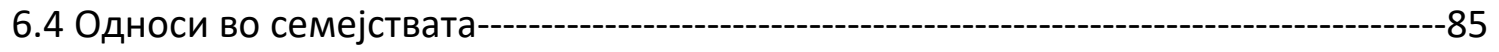

6.5 Демографска состојба-----------------------------------------------------------------------------85

6.6 Анализа на предностите, слабостите, можностите и заканите во нашето

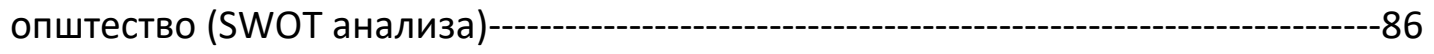

7. Дефинирање на структурата на концепт дизајн на веб платформа за промовирање на методологијата дизајн со општествено влијание-----------------88

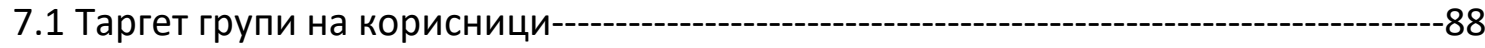

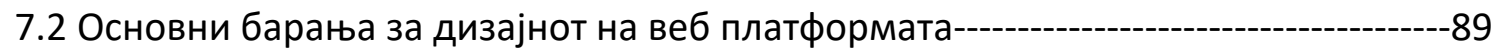




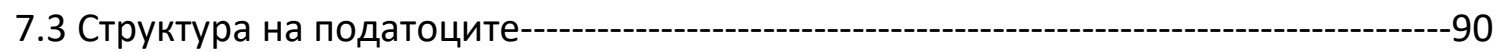

7.4 Структура на веб платформата--------------------------------------------------------------91

8. Детална презентација на разработениот концепт дизајн на веб платформа-----92

8.1 Избор на софтвер за изработка на веб платформата-----------------------------------92

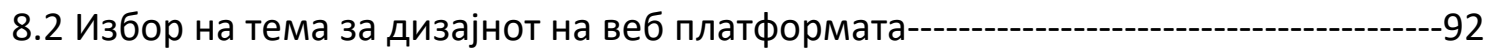

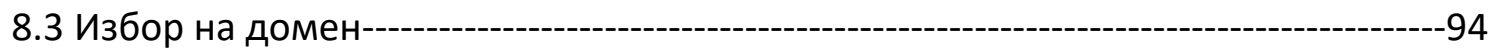

8.4 Избор на палета на бои-------------------------------------------------------------------------94

8.5 Дизјан на поединечните страни на веб платформата----------------------------------95

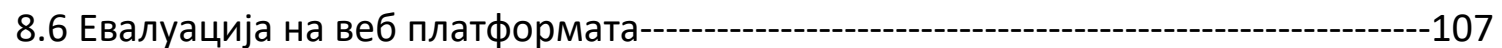

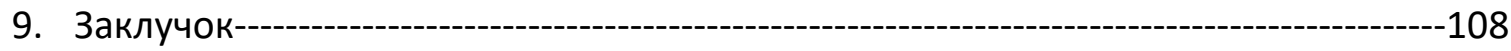

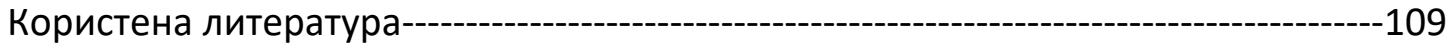




\section{1. Вовед}

Како што дизајнот бил стимул за техничките иновации во дваесеттиот век, во дваесет и првиот век дизајнот е стимул за општествените иновации. Со оглед на фактот дека дизајнот има потенцијал да придонесе за активирањето и подршката на општествените промени, слободно може да се именува како дизајн за општествени иновации.

Општественото влијание на дизајнот е феномен кој се забележува уште во далечната историја на човештвото. Интересот на дизајнерите за влијанието на нивните дела во општествените промени постои одамна, меѓутоа дизајн со општествено влијание како термин во честа употреба се појавил дури последнава деценија.

Со текот на годините пристапот на дизајнерите се променил многу, од фокусот врз надворешниот изглед на производите, нивните функции, употребливоста, различните начини за тестирање од страна на корисниците, па се до вклучувањето на потенцијалните корисници во процесот на дизајнирање. Во последно време, дизајнот со општествено влијание стана многу попопуларен, а како доказ за тоа се сѐ поголемиот број на организации и дизајнери кои почнуваат да се занимаваат со оваа проблематика.

Со зголемувањето на интересот на корпорациите за општественото влијание, способноста на дизајнот да влијае на промените во општеството сега се смета за многу важно. Денес се повеќе невладини организации го применуваат пристапот „дизајн размислување“ за да влијаат и да ги забрзаат промените во општеството. Иако дизајнот со општествено влијание е прилично нов пристап и сеуште постојат различни ставови за тоа што тој всушност претставува, тој станува се поатрактивно поле за истражување од страна на бројни истражувачи и разни организации.

\section{1 Цели на магистерската работа}

Главен поттик за избор на оваа тема за магистерска работа беше моето директно учество во меѓународниот проект „Дизајн со општествено влијание“. Во периодот 2015-2017 година Машинскиот факултет при Универзитетот „Св. Кирил И Методиј“ од Скопје беше вклучен во меѓународниот истражувачки и едукативен проект под наслов „Дизајн со општествено влијание”, инициран од одделот за дизајн на 
Универзитетот за уметности од Цирих, финансиран од фондацијата Меркатор од Швајцарија. Како студент на постдипломските студии по индустриски дизајн и маркетинг бев поканет да учествувам во улога на асистент на проектот. Во текот на реализацијата на активностите во рамките на овој проект бев вклучен главно во областа на видео етнографските истражувања. Една од моите најважни обврски беше изработката на магистерски труд кој ќе има за цел ширење на методологијата дизајн со општествено влијание на нашите простори.

Главната цел на моето истражување е проучување на суштината на пристапот општествено влијание на дизајнот и нејзиното значење во современото општество, да се проучат методите што произлегуваат од него и конечно да се даде придонес за промовирање, ширење и примена на знаењата и искуствата од реализираните активности од оваа област во нашето општество.

Како резултат на ова истражување креиран е концепт на веб-платформа наменета за

промовирање на методологијата дизајн со општествено влијание во нашата средина со цел да се даде придонес кон подигање на свеста за значењето на дизајнерите и дизајнерскиот начин на размислување како важен фактор за решавање на бројни проблеми во современите заедници и современото живеење. Веб платформата треба да овозможи размена на сознанијата помеѓу дизајнерите кои ги искусиле придобивките на применетите методи на дизајнирање со општествено влијание. Од друга страна веб платформата треба да им овозможи на засегнати општествени групи да ги презентираат своите проблеми за кои им е потребна помош. Од трета страна треба да овозможи вклучување на невладини организации кои ќе дадат свој придонес во поврзување на препознаените општествени проблеми со стручни тимови кои имаат знаење и умешност како да се помогне во решавање на истите.

\section{2 Методологија и методи на истражувањето}

Истражувањето во рамките на овој магистерски труд се одвиваше во следните фази:

- Проучување на расположивата литература и научни трудови од областа на дизајнот со општествено влијание 
- Запознавање со етнографски методи на истражување и втемелена теорија

- Преглед на резултатите и искуствата од реализирани работилници од областа на дизајнот со општествено влијание

- Анализа на резултатите од етнографското истражување на собраните материјали од реализираните работилници

- Систематизација на извлечените заклучоци и знаења од спроведеното етнографско истражување според дефинирани критериуми, во согласност со т.н. „втемелена теорија“ (grounded theory)

- Истражување на потребата од примена на методот дизајн со општествено влијание во нашето општество

- Дефинирање на основните барања за концептот на едукативна веб платформа за размена на дизајнерските искуства и знаења

- Изработка на прототип варијанта на едукативната веб платформа

- Евалуација на разработениот концепт

- Дефинирање на насоките за понатамошни истражувања 


\section{2. Хронолошки развој на дизајн со општествено влијание како методологија}

Тековната употреба на терминот „социјален дизајн“ или „дизајн со општествено влијание“ се обликувала последните десеттина години како резултат на специфични историски фактори. Појавата на нови политички средини, социјална иновација и претприемништво, подемот на активистичките практики во услови на глобални предизвици, како што се климатските промени и економските нееднаквости, развојот и употребата на дигитални и мобилни технологии се сметаат за историски фактори кои ја обликуваат тековната употреба на терминот. Процесите и резултатите на дизајнот со општествено влијание не се конкретно дефинирани, постојано има нови начини на негово практикување кои не можат да се предвидат [1].

Индустрискиот дизајн е главен виновник за масовното производство. Промовирањето на дизајнот со цел да се убедуваат луѓето да купуват работи што не им се потребни, е најосетливото прашање во денешно време. Дизајнот е една од најмоќните алатки со која човекот го обликува општеството. Тој треба да биде добро испланиран и осмислен, дизајнерот треба да биде општествено и морално одговорен за тоа, а во процесот на дизајнирањето да има разбирање за мислењата и потребите на јавноста. Така се зголемува вредноста на дизајнот и на самиот дизајнер кој влијае врз масовното производство и наметнува големи морални и општествени одговорности. Во денешно време неопходно е подигање на свеста на дизајнерите дизајнот да биде еколошки и општествено одговорен, ревулуционерен и радикален [16].

Во ова истражување е направен осврт кон феноменот наречен дизајн со општествено влијание преку истражување на неговата историја, различните пристапи од кои влече корени, како и неговата тековна состојба.

\section{1 Појава на идејата за дизајн со општествено влијание}

Уште во деветнаесеттиот век се јавила свест за пошироките општествени услови кои произлегувале од индустријализацијата, за јавната свест во врска со квалитетот на дизајнот на произведените предмети, како и за подобрување на квалитетот на 
предметите кои се произведувале. Тоа било поттикнато во Велика Британија од страна на дизајн реформаторите Вилијам Морис, Кристофер Дресер и Џон Раскин. Подоцна, при повоената реконструкција во Велика Британија, општествената улога на дизајнот добила особено импулс во 1940-тите и 50-тите кога дизајнерските студија и консултантите имале за цел да ги максимизираат граѓанските придобивки од дизајнот во исто време со зголемениот комерцијален потенцијал на дизајнот [1].

Освен во Велика Британија тоа движење се проширило и на глобално ниво кое предлагало алтернатива за конвенционалното потрошувачко живеење изразено преку работата на Виктор Папанек, Е. Ф. Шумахер, Џејн Џејкобс, Бил Молисон, Ралф Ерскин, Езио Манцини, како и помалку забележаните Денис Ливингстон и Еди Вокер [1].

Виктор Папанек во својата книга "Дизајн за реалниот свет" ја нагласува одговорноста на дизајнот во адресирањето на општествените проблеми, па оттогаш дизајнот во многу размислувања се развива со поголем акцент на својата проширувачка улога, не само како создавање на предмети, туку како суштински процес за иновации и креативност [2].

Во текот на историјата, дизајнерите започнале се повеќе да се фокусираат кон идните корисници на нивните дизајни. Денеска тие го користат пристапот дизајн со општествено влијание за да соработуваат со заедниците и да ко-креираат со нив за да развијат нови решенија кои ќе ги задоволат нивните потреби.

\section{2 Пристапи низ историјата кои придонеле во развојот на дизајн со општествено} влијание

Дизајнот со општествено влијание не се појавил оддеднаш, неговиот развој има длабоки корени. За да биде социјалниот дизајн каков што е денес заслужни се повеќе пристапи кои постојат пред појавата на социјалниот дизајн. Со проучување на тие пристапи се забележуваат многу сличности со социјалниот дизајн, што укажува на тоа дека влече корени од нив и всушност тие претставуваат основа за неговата еволуција. Такви пристапи од историјата кои може да се поврзат на одреден начин со дизајнот со општествено влијание има многу, но во ова истражување се разгледани само неколку позначајни. 


\subsection{1 Социјална одржливост}

Еден од тие пристапи е социјалната одржливост која според фондацијата „Тhe Young Foundation“ се дефинира како „процес за создавање одржливи, успешни места кои промовираат благосостојба со разбирање на она што им е потребно на луѓето од местата каде што живеат и работат [6].

\subsection{2 Копродукција}

Во контекст на соработка дизајнот со општествено влијание има сличности со копродукцијата за која постојат две широкоприфатени дефиниции. Едната е од Харис и Бојл кои ја дефинираат копродукцијата како "испорака на јавни услуги во рамноправен и реципрочен однос меѓу професионалци, луѓе што користат услуги, нивните семејства и нивните соседи [4]. Другата е од Д-р Едгар Кан според кој копродукцијата е како рамка и сет од техники што ги користат организациите на социјалните служби за да се пријави активно учество на клиентите во програмирањето на услугите [4].

\subsection{3 Социјални иновации}

Значаен придонес за појавата на дизајнот со општествено влијание се и социјалните иновации кои всушност се иновативни активности и услуги кои се мотивирани со цел да се задоволат социјалните потреби и кои се претежно развиени и раширени преку организации чии примарни цели се социјални, општествени [15]. Тие се разликуваат од бизнис иновациите кои најчесто работат за максимизација на профитот и се поттикнати од организации кои се најчесто мотивирани од максимизацијата на профитот [12].

\subsection{4 Дизајн за социјални иновации}

Како што дизајнот бил стимул за техничките иновации во дваесеттиот век, во дваесет и првиот век дизајнот е стимул за социјалните иновации. Во контекст на тоа што дизајнот има потенцијал да придонесе за активирањето и подршката на општествените промени, може да се именува како дизајн за социјални иновации [8]. Во создавањето на социјалните иновации освен дизајнерите постојат и други групи на 
луѓ⿱ кои со своите методи можат да учествуват во тоа, како што се социјалните претприемачи, јавните службеници, комерцијални комапнии, активисти, или појавата на социјалните инвестиции преку соработка помеѓу луѓе од различни сектори и дисциплини [15]. Во овој случај дизајнерите треба да прифатат дека и другите дисциплини се креативни па да соработуваат поблиску со нив со цел генерирање на социјални иновации, како и да вклучат методи и алатки кои имаат потенцијал да го поддржат развојот на цврсти предлози и нивна имплементација во реални контексти.

\subsection{5 Колаборативни услуги}

Корисниците кои се вклучени во дизајнирањето и изработката на решенијата се нарекуваат водечки корисници и се карактеризираат со тоа што честопати со гордост го откриваат на останатите потенцијални корисници тоа што го развиле. Како резултат се јавуваат корисници кои што се заинтерсирани за усвојување на решенија кои се развиени со помош на водечките корисници. Тоа е основа за постоење на иновативни системи ориентирани кон корисникот со цел да ги заменат системите за производство на иновации под одредени услови или да ги надополнат [20]. Колаборативните услуги создаваат позитивно влијание врз општеството бидејќи генерираат решенија за многу социјални проблеми и ја зајакнуваат социјалната кохезија, поради што се сметаат за социјални иновации [3].

\subsection{6 Дизајн размислување}

Денес дизајн размислувањето се смета за креативен и фаворизиран менаџментски пристап. Тоа е пристап кој освен во дизајнот има примена и во други полиња, а се карактеризира со способноста за справување со проблеми кои се непознати или нецелосно дефинирани [15].

\subsection{7 Дизајн со фокус на корисникот}

Од 70-тите години, почнувајќи од САД, на корисниците почнало да им се дава простор за нивна улога да обезбедуваат експертиза и да учествуваат во информирањето, идеите и концептуализацијата на активностите во раните фази на 
дизајнирање. Овој пристап бил наречен дизајн со фокус на корисникот кој има многу сличности со социјален дизајн [13]. Предизвикувачки и инспирирачки во создавањето на иновации преку дизајн со фокус на корисникот се голем број на корпорации кои ги прифаќаат иновациите на корисниците и потрошувачите, па ги претвараат во безбедни профитабилни производи на масовниот пазар. Таквите успешни корпорации и постојаната пазарна логика придонесуваат во опстанувањето на центрите за иновации, а изворот на иновациите и нивното тестирање е овозможено и прифатливо од тековната менаџерска идеологија [15].

\subsection{8 Кокреација}

Во создавањето на решенија за технолошките промени и потикнувањето на создавањето иновација, големо влијание има дизајнерот кој во тој процес вклучува корисници или потрошувачи кои се сметаат за потенцијални кокреатори [15]. Кокреацијата се однесува на секој чин на колективна креативност, односно креативност што ја делат двајца или повеќе луѓе и е многу широк поим со апликации од физички до метафизички и од материјални до духовни.

\subsection{9 Кодизајн}

Кодизајн е специфичен пример за кокреација и претставува колективна креативност што се применува во целиот процес на дизајнирање. Поборниците на отворени иновации и кодизајн сметаат дека ниту еден соработник не поседува доволно знаење потребно за да се развијат нови производи, услуги или искуства, туку дека е потребно да се работи тимски со соработници од различни сектори и дисциплини. Во испитувањето кои се причините и како може да настане отворена иновација и кодизајн, Чесброг проучува дека секое едно претпријатие кога создава иновации, освен внатрешните генерирани идеи, треба да биде отворено и за прифаќање на надворешни идеи и така со таквото комбинирање на внатрешни и надворешни идеи, претпријатијата ќе можат да вршат подобро оценување на идеите врз основа на нивната комерцијална одржливост [15]. Користењето на кодизајнот во социјалниот дизајн е со акцент на креативноста на дизајнерите и луѓето кои не се обучени за дизајнирање, а работат заедно во процесот на развој на дизајнот [13]. 


\subsubsection{0 Партиципативен дизајн}

Некои од ограничувањата на дизајнот за социјални иновации може да се надминат со партиципативниот дизајн [11]. Како најблизок и најсличен пристап со социјалниот дизајн може да се смета партиципативниот дизајн кој претставува дизајнирање со фокус на луѓето што учествуваат во процесот на дизајнирање како ко-дизајнери. Како некои од претходно споменатите пристапи и партиципативниот дизајн е всушност дизајнирање за употреба пред да се случи употребата - дизајн за употреба пред употреба [5]. Врз основа на овие искуства заклучено е дека знаењето на работниците за работата со претставувањето на нивните интереси преку учеството на работниците во процесот на дизајнирање се применува директно. Со тој пристап се овозможило меѓусебно учење помеѓу дизајнерите и работниците [10]. Всушност, кај партиципативниот дизајн оние кои се засегнати од дизајнот треба да имаат збор во процесот на дизајнирање [5]. Имајќи за цел да го нагласува учеството на корисниците во развојот на информатичките технологии, партиципативниот дизајн во време од четири децении во борбата за влијание на работниците врз информатичката технологијата на работното место еволуираше во погенерална методологија на дизајнирање. Фокусирајќи се на методите и техниките за учество на сите учесници во технологијата што се развива, партиципативниот дизајн станува помалку политички, а повеќе прагматичен [19]. Градењето на свест кај луѓето, нивно доведување во дизајнот на невидливите посредувачки структури околу нив, барањето на начини како дизајнот да престане да биде обележуван само со почеток и крај помеѓу засегнати страни во една организација е токму целта на занимавање на партиципативниот дизајн [17]. Вклучувањето на сите видови корисници на нов систем на различни начини во дизајнот на релевантните делови на системот е предмет на методот на партиципативниот дизајн. За разлика од клиентот, корисниците имаат различни улоги и компетенции во организациониот живот воопшто. За да се третираат како група на корисници, а не како засегнати страни, дизајнерите треба да ги земаат во предвид потребите на надворешните добавувачи и клиенти на компанијата кои можат, но не мораат на некој начин да имаат интеракција со системот, притоа да имаат способност да ги идентификуваат различните групи и нивните потреби, решавајќи ги конфликтите на професионален начин. 


\subsubsection{1 Дизајн со општествено влијание}

Освен постоењето на историските социјални и дизајн пристапи, за појавата на дизајнот со општествено влијание има големо влијание и политичкото опкружување. Голем број политички промени придонесле за подемот на практикувањето и истражувањето на дизајнот со општествено влијание, познат и како социјален дизајн. За ова фигурираат пет клучни движечки сили [1].

- Од 1980-тите се развиле пристапи за нов јавен менаџмент „New Public Management (NPM)“ во централната и локалната власт;

- Имплементирање на мрежното владеење „Network Governance (NG)“ каде владините институции работат во покоординативен капацитет на услугите и јавноста;

- Мерки за штедење;

- Поттикот „Nudge“ и промената на однесувањето „Behaviour Change“ се исклучок каде политичките аспирации директно го обликувале дизајнот на услугите, а особено на дигиталните услуги;

- Појавата на големи податоци „Big Data“ и отворени податоци„Open Data“ како нови области кои произлегуваат од конвергенција на комерцијален, технолошки и менаџмент развој.

За социјалниот дизајн може да се каже дека има преклопена историја со традиционалниот дизајн, поради тоа се забележуваат исти пионери. Но, за разлика од традиционалниот дизајн, социјалниот дизајн инволвира и нестручни практичари, вклучување на политички бирократи, блиски врски со не-дизајн полиња итн [1].

Некои практичари социјалниот дизајн го сметаат како дисциплина - систематски стекнат и применет сет на професионални вештини, а некои го сметаат како пристап флексибилна алатка што ја користат различни професионалци во повеќе сектори. Дизајнерските професии треба да бидат одговорни за општествените промени почнувајки од индустриски дизајнери се до дизајнери на општества, а тоа значи дека и гледиштето на институциите за дизајн кон економски и индустриски цели е датирано [14]. Последниве години се зголемил интересот на дизајнери и архитекти за социјалниот дизајн, па поради тоа се појавуваат се повеќе курсеви и програми за образование во оваа област [9]. 
Со комерцијалниот дизајн производите/услугите се дизајнираат за профит, додека со социјалниот дизајн производите/услугите се дизајнираат за општеството со разгледување на општеството [2], односно во процесот на социјалниот дизајн се зема во предвид влијанието на дизајните кои се наменети за поединците, животната средина, заедницата и поширокото опкружување [7].

Со текот на годините пристапот на дизајнерите се променил многу, од фокусот на дизајнираните артефакти и нивните функции, на употребливоста, на различни начини за тестирање на корисници, на проучување на употребата и вклучување на потенцијалните корисници во процесот на дизајнирање [5].

Во последно време, социјалниот дизајн стана попопуларен и како доказ за ова сѐ поголем број на организации и дизајнери почнуваат да се занимаваат со оваа тематика. Со зголемувањето на интересот на корпорациите за социјалното влијание, способноста на дизајнот да влијае на промените во општеството сега се смета за многу важно. Денес се повеќе невладини организации го применуваат принципот „дизајн размислување“ за да влијаат и да ги забрзаат промените во општеството [2].

Секој обичен човек може да ги искористи своите дизајнерски вештини и притоа да има влијание во процесот на дизајнирање на општествените промени. Дизајнерите со своето знаење и мудрост треба да влијаат врз потикнувањето на природните способности кај секој обичен човек. Затоа постојат институциите за дизајн каде што се вршат организирани дизајнерски активности со кои се развиваат и создаваат креативни идеи кои би влијаеле кон создавањето на подобри социјални промени. Од тука би произлегло прашањето која е улогата на дизајнерите во процесот на општествените промени, а одговорот би бил дека дизајнерите се група пионери водени од знаење и експертиза за помагање на другите [14].

\section{3 Споредбена анализа на истражуваните пристапи}

На крајот од извршената анализа на хронолошкиот развој на социјални и дизајн пристапи низ историјата извлечени се нивните главни карактеристики и презентирани во една споредбена табела (Таб. 1) од која можат лесно да се извлечат сличности и разлики помеѓу нив. 
Таб. 1 Пристапи кои придонеле за појавата на дизајнот со општествено влијание

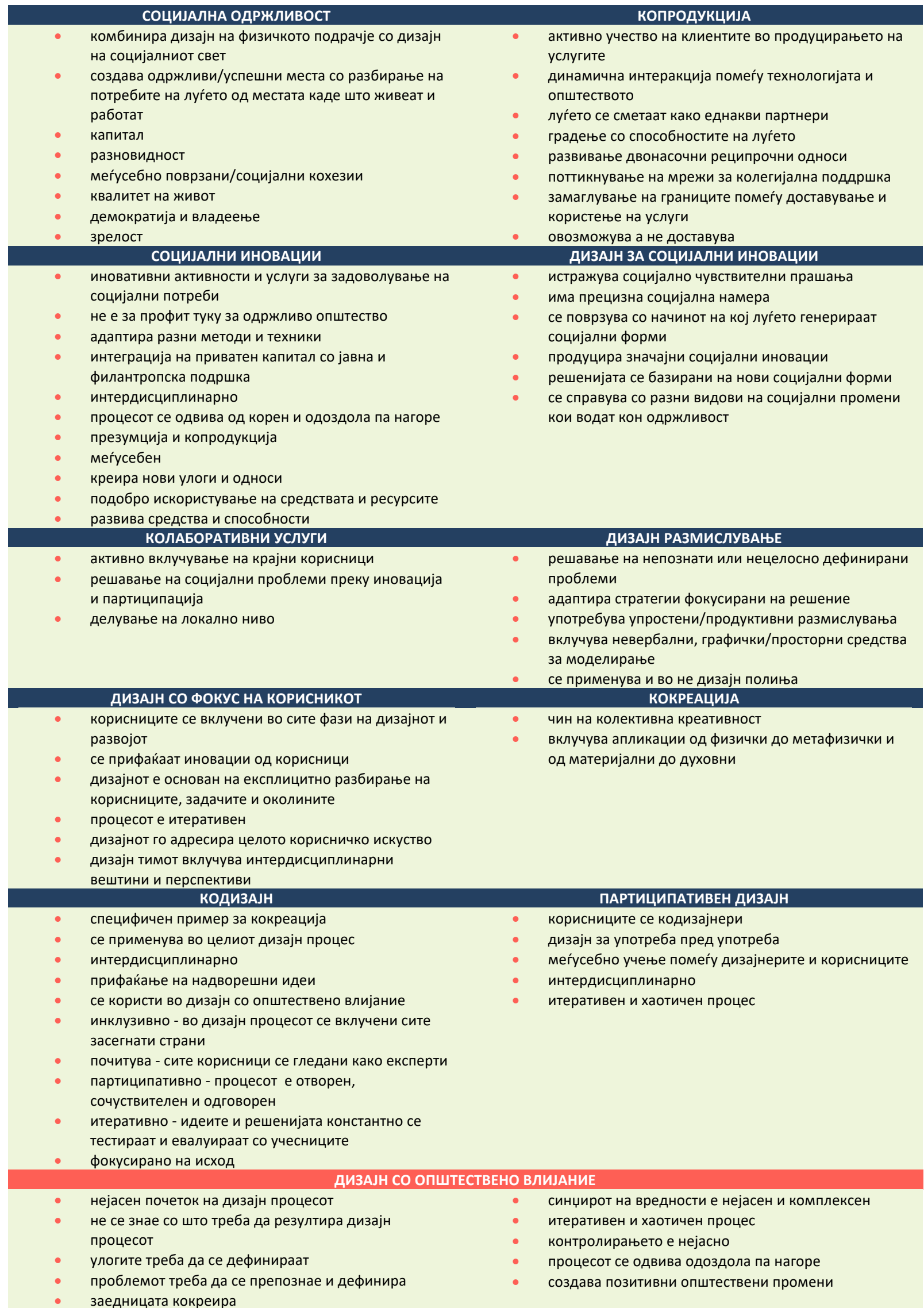




\section{3. Применета методологија на истражување}

\section{1 Етнографско истражување}

Се претпоставува дека основа на етнографијата е да ги поддржи дизајнерите да ги решат вистинските проблеми со општествено одржливи решенија, преку истражување на преовладувачките концепции на „корисници“ и нивните практики [21]. За документирање на теренски истражувања и пренесување на знаењата, дизајнерите и развивачите на нови технологиии ја користат методологијата видео етнографија.

Методите кои традиционално се користат од антрополози, како што се секундарна анализа на податоци, теренска работа, набљудување на активности од интерес, земање на белешки од терен и набљудувања, учество во активности за време на обсервациите и спроведување на разни форми на неформално и полуструктурирано етнографско интервјуирање се нарекуваат основни класични етнографски методи [22].

Аудио и видео снимката за разлика од претходните едукативни материјали кои се потпираа на земање белешки со цел да се долови однесувањето на социјалните чинители, овозможува попрецизни и подетални анализи на динамиката на човековите општествени средби на самото место. Опремата за снимање служи како суштинска алатка, таа им овозможува на очите и ушите на истражувачите да го запознаат појавното структурирање на исказите, гестовите, изразот на лицето, насоката на погледот, тишината, разговорот и други општествени активности.

Наместо да обезбеди општо објаснување за општеството, етнографијата се фокусира на мал аспект на едно општество, како на пример одредена социјална активност, перформанси или процес. Набљудувањето на учесниците подразбира пролонгирано вклучување на истражувачот во општествена група користејќ ги сите негови сетила за да се почувствува што се случува кај секој од членовите на групата, имајќи ги во предвид ограничувањата на статусот на аутсајдер и неможноста за вистинска интерсубјективност.

Поради фактот што видео етнографијата зависи од квалитетот и начинот на кој што се снимени податоците преку објективот на камерата, видео етнографите треба да се обучуваат како да бидат подискретни при снимање и како да се минимизира нивната присутност како набљудувачи. Видео етнографите треба да имаат и осет за она што треба да се опфати во рамките на сликата, посебно за да се постави објективот така за 
колку што е можно повеќе да се вклучат сите учесници во социјалната ситуација и физичката средина. Камерата кај видео етнографијата не е статична поради фактот што учесниците треба да се движат постојано во нивните средини. Колку што е важно снимањето, толку е важна и звучната компонента на видео етнографијата, односно квалитетот на звукот. Видео снимките се доста изржливи, може да се премотуваат, да се забавувааат, враќаат назад, притоа овозможувајќи им на гледачите и истражувачите да ги анализираат некои особини кои лесно се пропуштаат при само едно набљудување. Документирајќ преку видео записите, истражувачите ги анализираат изразите на лицата, преку звукот-тонот на нивниот глас, нивните гестови, ставови и акции во општеството каде создаваат социјални средби. Покрај снимените податоци, видео етнографијата се потпира и на транскрипции на снимките, кои се селективни репрезентации на она што е запишано и ги одразуваат фокусните интереси на истражувачите.

Бидејќи видео етнографијата не може сама да ги долови животните светови на целото општество или на одредена општествена група, туку обезбедува документација на теренот, координирани акти од општествен поредок и културни ориентациии, потреба е да биде комбинирана со останатите етнографски методологии кои се вклопуваат во пошироки социјални временски рамки и различни димензии на човековото искуство [23].

\section{2 Втемелена теорија}

Втемелената теорија е дизајнирана со цел да отвори простор за развој на нови, односно контекстуализирани теории. Како пионери на втемелената теорија се сметаат социолозите Барни Гласер и Анселм Штраус кои биле незадоволни од начинот на кој постоечките теории доминирале во социолошките истражувања. Според нив истражувачите имале потреба од метод што ќе им овозможи да преминат од податоци во теорија за да може да се создаваат нови теории кои би биле специфични за контекстот по кој биле развиени. Наместо да се потпираат на аналитички конструкции, категории или варијации од претходно постоечки теории, тие теории би биле втемелени во податоците од кои се појавиле [25]. 
Постојат различни извори и процедури од каде произглегуваат податоците на втемелената теорија. Тоа може да е со интервјуирање и набљудување, преку владини документи, видео снимки, писма, весници, книги и слично. Секој од тие извори може да се кодира на ист начин како интервјуа и набљудувања. Истражувачите се одговорни за применувањето на втемелената теорија која покрај откривање на релевантни услови, треба да утврди како актерите реагираат на променливите услови и на последиците од нивните постапки.

Покрај својата флексибилност и опширност во рамките на границите, втемелената теорија има специфични постапки за прибирање и анализа на податоците. За да се спроведе студија, истражувачите на втемелената теорија мора да ги познаваат таквите постапки и закони кои што се меѓусебно поврзани.

Собирањето и анализата на податоци се два меѓусебно поврзани процеси. Додека во втемелената теорија анализата се врши врз основа на првите малку собрани податоци, многу квалитативни истражувачи започнуваат со системска анализа откако ќe соберат поголем број податоци. Тоа ги прекршува темелите на овој метод. Спроведувањето на постапките за собирање и анализа на податоци систематски и последователно му овозможува на истражувачкиот процес да ги опфати сите потенцијално релевантни аспекти на темата веднаш штом ќе се согледаат.

Основни единици на анализата се концептите, така истражувачите вршат концептуализација на податоците, наместо фактички податоци сами по себе. Бидејќи теориите не може да бидат засновани врз вистинските случки или активности какви што се пронајдени или пријавени, т.е. не може да останат сурови податоци, секој инцидент, настан или случување кога се зема мора да се анализира како потенцијален индикатор на феномени, кои на тој начин даваат концептуални етикети.

Категориите се формираат со групирање на повеќе концепти кои што се однесуваат на еден ист феномен, но не сите концепти може да формират категории. Категориите се развиени и поврзани, тие се на повисоко ниво и се поапстрактни од концептите што ги претставуваат. Тие претставуваат „камен темелник“ за развој на теоријата и обезбедуваат средства со кои теоријата може да се интегрира. Категориите се создаваат преку ист аналитички процес на споредување со цел да се истакнат сличностите и разликите што се користат за да се создадат концепти на пониско ниво. Категориите може да се поврзат едни со други и да формираат теорија. 
Примероците опфатени во втемелената теорија продолжуваат на теоретска основа, не само во смисла на цртање примероци на специфични групи од поединци, единици на време и слично, но и во однос на концептите, нивните својства, димензии и варијации. Кога се започнува проектот, истражувачите го доведуваат до некоја идеја за феноменот што сакаат да го проучуват, а подоцна врз основа на ова знаење за студијата може да се изберат групи на поединци, организација или претставник на заедницата за тој феномен.

При анализирање се вршат постојани споредби. Кога некој инцидент ќе биде забележан, потребно е да се спореди со други инциденти, кои им се сличностите, а кои разлики. Резултирачките концепти се етикетирани како такви, а со текот на времето тие се споредуваат и групираат. Со спроведувањето на споредби се постигнува поголема прецизност (групирање на слични феномени и само феномени) и конзистентност (секогаш се групира како слично). Поради регуларност и разбирање за тоа каде таа регуларност не е застапена, мора да бидат испитани сите податоци. На пример, да претпоставиме дека истражувачите забележуваат дека медицинските сестри редовно реагираат сентиментално кога нивните педијатриските пациенти се подложени на физички трауматски искуства. Но, ако истражувачите исто така забележуваат дека кога медицинските сестри се особено зафатени, ја префрлаат сентименталноста на друг член на здравствениот тим или член на семејството, се појавува варијација на оригиналниот модел.

Процесот е вграден во теоријата и има неколку значења. Процесот како анализа може да значи разделување на феномен надолу во стадиуми, фази, чекори или процесот исто така може да означува намерна акција/интеракција која не е нужно прогресивна, туку се променува како одговор на преовладувачки услови.

Истражувачите не можат лесно да ги следат и запомнат сите категории, својства, хипотези и генерирачки прашања кои се развиваат од аналитичкиот процес, па затоа постои систем за тоа кој всушност е составен дел на водење на втемелена теорија, а тоа е пишувањето на теоретски белешки. Тоа не се само идеи, туку таквите белешки се користат при формулирањето и ревизијата на теоријата за време на истражувачкиот процес. Со првите кодирани сесии започнува пишувањето на белешки и трае до крајот на истражувачката интеграција на анализата што ќе резултира. 
Во текот на процесот на инстражување треба да се развијат и потврдат хипотезите за односите помеѓу категориите. По развивањето на хипотезите за односите помеѓу категориите потребно е да се направи проверка и ревизија на истите доколку има потреба. Главна карактеристика на втемелената теорија е токму постојаното проверување и ревидирање на хипотезите за време на нивното истражување се додека не се потврдат сите докази собрани од интервјуа, забелешки или документи кои се однесуваат на феномените кои што се испитуваат. Со процедурите за верификација односно пребарување на негативни и квалификувани докази, настануваат постојани ревизиии, па таквиот процес резултира со сосема робусни анализи.

Значајно во истражувањето на оние кои го користат пристапот на втемелена теорија е тестирањето концепти и нивните односи со колегите кои имаат искуство во истата суштинска област. Отварањето на една анализа, а испитувањето на другите, помага при заштита од предрасуди, а размената на мислења и разговорите со други истражувачи честопати доведуваат до нови сознанија и зголемена теоретска чувствителност. Можностите за зголемување на веројатноста за колаборативна анализа се создаваат со истражувачки проекти спроведени од тимови. Независно од микроскопското истражување, потребно е да се врши анализа на пошироките структурни услови кои влијаат врз феноменот, како на пример економските услови, културните вредности, политичките трендови, општествените движења и така натаму.

Основен аналитички процес кој што го користат истражувачите е кодирањето. Во теоретското истражување постојат три основни видови на кодирање: отворено, аксијално и селективно.

Процесот на интерпретација со кој што се анализираат податоците и чија цел е да им дадат на истражувачите нови согледувања преку пробивање на стандардните начини на размислување или толкување на феноменот што се рефлектира во податоците, се нарекува процес на отворено кодирање. Со отвореното кодирање се врши споредба на сличностите и разликите на настаните/дејствата/интеракциите со други настани/дејства/интеракции и така може да се групираат заедно едни со други и да формираат категории и подкатегории. Со примена на отвореното кодирање им се овозможува на истражувачите да ја пробијат субјективноста и пристрасноста. 


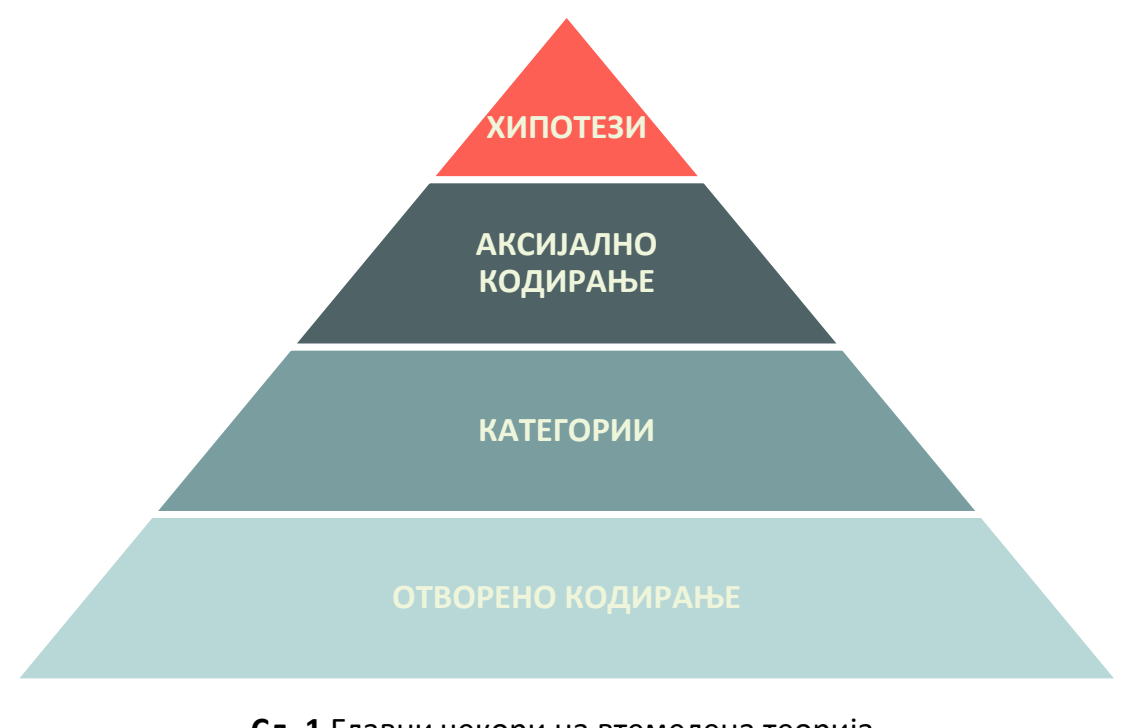

Сл. 1 Главни чекори на втемелена теорија

Процесот на поврзување на категориите со нивните поткатегории и односите тестирани наспроти податоците се нарекува аксијално кодирање. Се додека не се верифицираат со дојдовните податоци, сите хипотетички односи предложени дедуктивно за време на аксијално кодирање се сметаат за привремени. Дедуктивно доаѓање до хипотези кои немаат смисла во споредба со вистинските податоци мора да бидат ревидирани или отфрлени (Сл. 1).

Процес кој се појавува во подоцнешните фази на студијата и според кој сите категории се обединети околу категоријата „јадро“, а категориите за кои е потребна дополнителна експликација се пополнуваат со описни детали, се нарекува селективно кодирање. Главен феномен на студијата претставува основната категорија која може да произлезе од веќе идентификуваните категории или можеби е потребен поапстрактен термин за да се објасни главната појава. Сите други категории секогаш ќе бидат во врска со основната категорија како услови, стратегии за акција/интеракциски последици. Интеграцијата на категориите може да се направи полесно со претставување преку дијаграми.

Втемелената теорија може да даде одреден степен на предвидливост, а нејзините постапки се дизајнирани така да би можело да се развие добро интегриран сет на концепти кои обезбедуваат темелно теоретско објаснување на општествените феномени кои се изучуваат [24]. 


\section{4. Преглед на резултатите и искуствата од реализираните работилници од областа на дизајн со општествено влијание}

Меѓународниот проект „Дизајн со општествено влијание“ беше реализиран како соработка помеѓу студенти и наставници од универзитети во Швајцарија, Кенија, Македонија, Кина и Индија, а учествуваа и невладини организации и образовни партнери (Сл. 2-3). Повеќе од две и пол години се истражуваше дизајнот за општествени иновации и неговото влијание врз образованието на идните дизајнери [26].

Целокупната работа во рамките на проектот „Дизајн со општествено влијание” ми овозможи проширување на моите знаења со нови методолгии на работа во областа на дизајнот. Најголемо значење во оваа насока има мојата улога на набљудувач опсервер во две реализирани работилници на тема дизајн со општествено влијание. Искуствата од моето учество во нив се презентирани како дел од овој магистерски труд. Главна цел при тоа ми беше извлекување на вредни заклучоци за поконкретно осознавање и потемелно дефинирање на процесот на дизајнирање при реализација на проектите од областа на дизајн со општествено влијание.

Проектот се одвиваше во две насоки: образование и истражување. Образовната насока се реализираше преку спроведување на летни школи и работилници со истражување на терен кои овозможија меѓународно и интердисциплинарно искуство. Истражувачката насока беше фокусирана на проучување теоретски и методолошки прашања кои резултираа со вредни знаења за образованието и апликациите од областа дизајн со општествено влијание. Со помош и подршка на локални експерти, студенти и факултетите, беа тестирани методите на општествениот дизајн преку работа на вистински случаи. Беа одржани пет меѓународни работилници фокусирани на општествените предизвици и примена на дизајнот за решавање на проблеми во различни контексти, а темите беа засновани на постоечки проекти предложени од невладините организации со запазување на академските и образовните интереси.

Програмата беше подржана од невладините организации како партнери на проектот кои со својата експертиза, знаење и мрежа на контакти им овозможија на студентите да работат на вистински случаи во оваа област, а притоа делуваа како 
ментори и критични набљудувачи кои направија евалуација на методите и пристапите кои се користеа во рамките на програмата.

Во сите работилници учествуваа околу 140 студенти кои успешно ги поврзаа дизајнерските вештини, методите за дизајн и процесите на дизајнирање со реални случаи и општествени предизвици. Беа воведени методи на општествен дизајн и методи на меѓукултурна соработка. Студентите имаа можност да прототипираат и тестираат во реални услови. Целиот процес на дизајнирање беше документиран онлајн во блог формат од страна на студентите.

Работилниците беа придружувани од интернационален истражувачки тим. Во истражувањето беа користени квалитативни истражувачки алатки како набљудување, видео етнографија, интервјуирање, визуелен и доказен материјал во вид на видео снимки, фотографии, скици, модели и сл.

Студентите од Машинскиот факултет од Скопје беа вклучени во втората работилница која се одржа во Скопје во периодот мај/јуни 2016 година, како и во третата која се одржа во Мачакос, Кенија, во текот на април 2017 година.

Во ова поглавје најпрво се презентирани во главни црти проектите реализирани во рамките на работилниците одржани во Скопје и Мачакос, Кенија. Фокусот е ставен на темите на проектите, инволвираните учесници (членови на заедниците, студенти од различни профили, невладини организации), реализираните резултати. На крајот од ова поглавје извршена е анализа и споредба на резултатите од реализираните проекти, и конечно, извлечени се заклучоци кои имаат за цел поконкретно дефинирање на суштината на проектите од областа дизајн со општествено влијание.
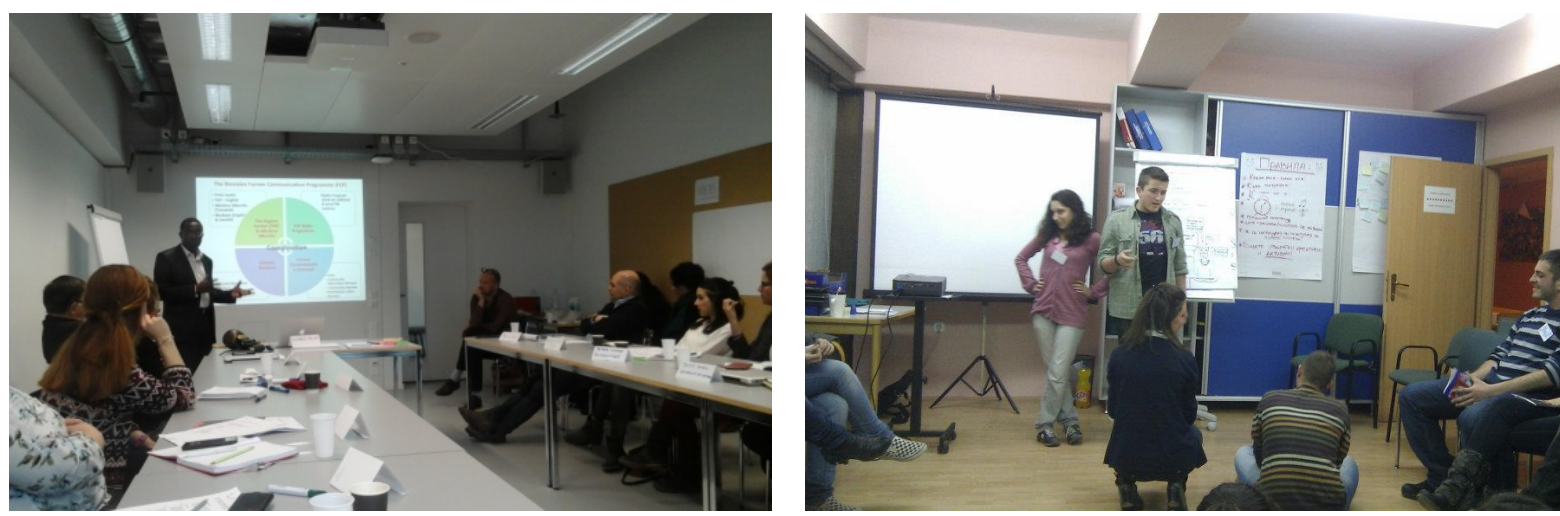

Сл. 2-3 Реализацијата на проектот „Дизајн со општествено влијание” 


\section{1 Работилница „Проекти за Македонија - учење едни од други“, Скопје, мај/јуни 2016 година.}

Работилницата реализирана во Скопје траеше 3 недели во текот на мај/април 2016 година. Се разработуваа проекти за Македонија опфаќајќи голем број деловни случаи поврзани со моменталната локална ситуација. Работилницата беше реализирана како соработка помеѓу Универзитетот за уметности од Цирих, Машинскиот факултет при Универзитетот "Св. Кирил и Методиј“ во Скопје и невладините организации Свисконтакт и ИМЕ Македонија (Сл. 4-8).

Целта на оваа работилница беше да се создаде меѓукултурна и интердисциплинарна соработка, размена на едукативни искуства и знаења, да се извршат истражување, анализа и концепција за развој на реални деловни случаи, да се создадат концепти за брендирање, комуникација, дизајн на производи и инфраструктура, да се формулират деловни стратегии за реалната економска состојба и да се создаде етнографска студија за методологија и процесите на дизајнирање.

Меѓународните и интердисциплинарните тимови на студенти од Швајцарија и Македонија, под надзор на наставниците од Цирих и Скопје, работеа заедно на решавање бизнис случаи препознаени и предложени од страна на Свисконтакт:

1. Национален парк Маврово

2. Био-компостирање со црви

3. Логистика за природна храна - органски овошје и зеленчик, свежи и преработени

4. Економско зајакнување на жените од Дебар и с. Броштица, Дебарско

Студентите соработуваа со компании, установи, лица и организации, предложени од Свисконтакт, во врска со предложените бизнис случаи во Македонија. Фокусот беше ставен на подобрување на можностите за вработување. Се генерираа решенија за креативна поддршка на туризмот, стартапи и млади претприемачи, владини организации, природна храна, како и економско зајакнување на жените.

Во оваа работилница освен студенти од областа на дизајнот учествуваа и студенти од областа на индустриско инженерство и менаџмент. Беа формирани четири тима, а секој тим се состоеше од: четворица студенти од студиската програма стил и дизајн од одделот за дизајн при Универзитетот за уметности во Цирих, четворица студенти од 
студиската програма индустриски дизајн и двајца студенти од студиската програма индустриско инженерство и менаџмент на Машинскиот факултет при Универзитетот „Св. Кирил и Методиј“ во Скопје. Во секој тим беа вклучени и по двајца студенти од студиската програма индустриски дизајн во улога на посматрачи, опсервери, кои ги документираа целокупните активности при реализација на проектите.

Во текот на реализацијата на активностите беа користени повеќе принципи, методи и техники како: истражување на терен, истражување од работно место, дефинирање и редефинирање на дизајнерскиот проблем, интервјуа, етнографски истражувања на видео материјали, опсервации, анализа на предностите, слабостите, можностите и заканите (SWOT анализа), фокус група, синџир на вредности, ко-креација, метод на молскавица, аналогна инспирација, сценарио техника, прототипирање и филтрирање. Посебен придонес дадоа студентите од студиската програма индустриско инженерство и маркетинг преку препознавање на бизнис потенцијалите на понудените решенија и изготвување бизнис и финансиски планови за секој проект поединечно.

Како резултат од работилницата произлегоа четири проекти изработени од членовите на четирите тима:

- Концепти за околината на Маврово,

- Урбан центар за креативност и одржливост,

- Брендирање на природна македонска храна,

- Нова интерпретација на македонската традиција.

Во продолжение е дадена анализа на работата на сите четири тимови преку:

- Назив и опис на бизнис случаите предложена од Свисконтакт

- Вклучени заедници, институции

- Опис на зададениот бизнис проблем

- Очекувани резултати

- Како студентите ги препознале и дефинирале постоечките проблеми

- Понудени решенија на проблемот

- Колку реализираниот проект ја постигнал целта на поставениот бизнис проблем. 
Процесот на работа беше следен од бројни проблеми во реализацијата, почнувајќи од лоша комуникација со предложените заедници, несогласувања во тимовите поради различната посветеност на работата, кратки временски рокови итн.
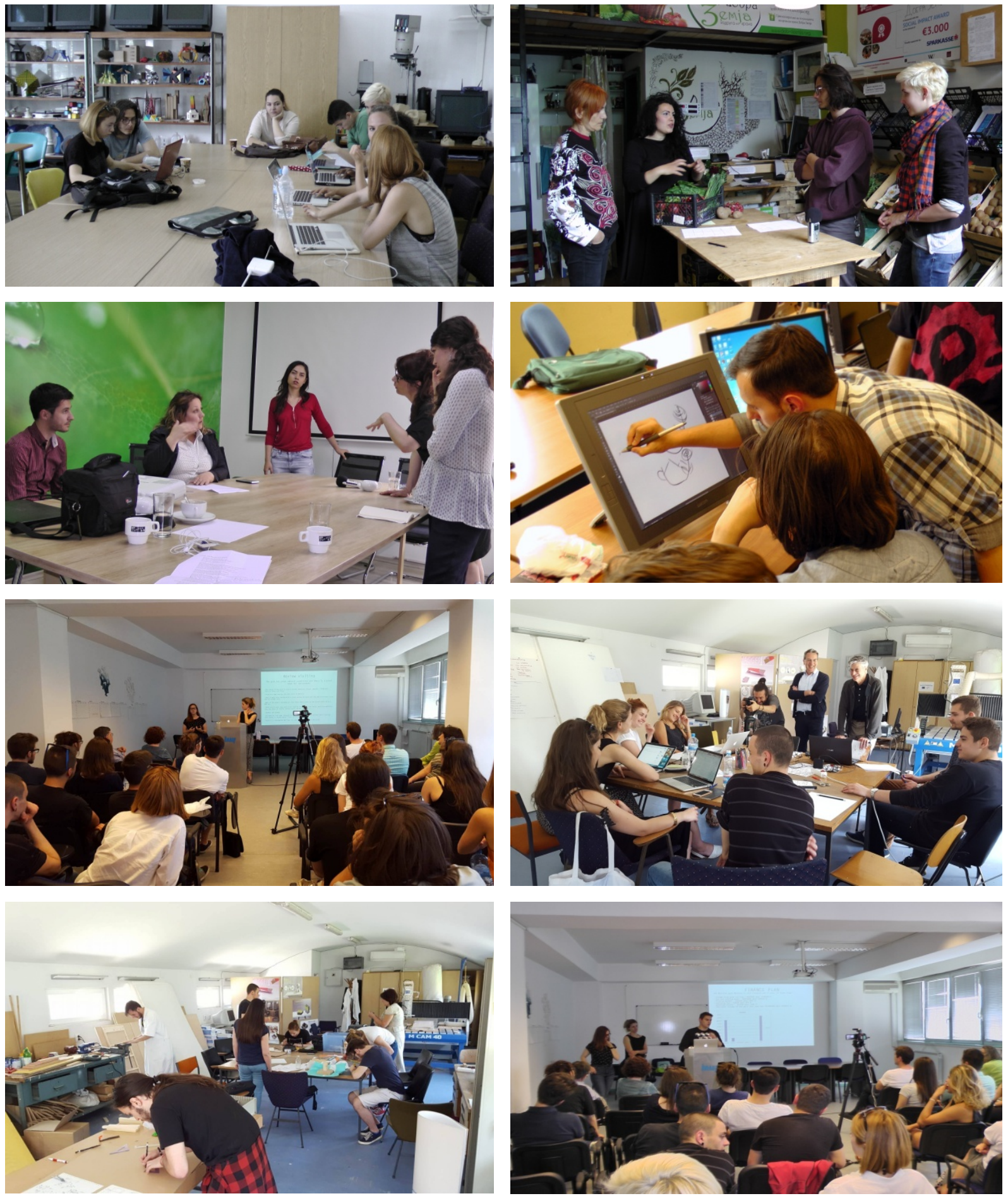

Сл. 4-8 Работилница бр.2 - „Проекти за Македонија - учење едни од други“, Скопје, Македонија 


\section{Проект 1: Концепти за мавровската околина}

\section{Наслов на бизнис проблемот предложен од Свисконтакт:}

- Национален парк Маврово

\section{Заедници поврзани со бизнис проблемот:}

- Вработените во Националниот парк Маврово,

- Локални и странски гости,

- Ученици од училиштата што доаѓаат на екскурзии,

\section{Опис на зададениот бизнис проблем:}

- Маврово е најбогатиот национален парк во Македонија со ретки растителни и животински видови. Има голем број посетители и многу можности што им ги нуди, а голем број организациони прашања кои влијаат на квалитетот на престој во овој простор.

\section{Очекувани резултати:}

- Да се најдат решенија за проблемите на собирање и транспорт на отпадоците, отстранување на диви депонии.

\section{Кои проблеми ги препознаа студентите?}

Студентите го посетија Националниот парк Маврово, извршија повеќе интервјуа со вработените во управата, но и со тамошните жители и бројни посетители. По извршената анализа на собраните информации тие заклучија дека има бројни проблеми чие решавање би придонело за промовирањето на паркот и подобри услови за посетителите и за сите засегнати страни.

- Со развивање на инфраструктурата би се обезбедило подобро менаџирање и одржување на паркот.

- Подобрата комуникација помеѓу управата на паркот, жителите и сопствениците на приватните скијачки центри треба да ја обезбеди синергијата на паркот во иднина.

- Ублажување и решавање на тешките проблеми со отпадот би можело да се реализира со сеопфатната едукативна кампања за превенција на отпадот.

\section{Какви решенија понудија?}

Како резултат на тимската работа студентите понудија пакет решенија презентирани како проект под наслов „Концепти за мавровската околина“ (Сл. 9-15, Сл. 16-22):

- Брендирање - лого на Националниот парк Маврово

- Мапа на паркот со икони за означување

- Патокази, инфраструктурни знаци

- Информативна брошура

- К Кампања за отпад и почиста околина, правилно собирање на отпадот со икони за едукација на однесувањето на посетителите

- Веб страна

- Дизајн на настрешница со клупи за одмор на посетителите

- Дизајн на корпи за отпадоци

Колку реализираниот проект ја постигна целта на поставениот бизнис проблем?

Студентите понудија квалитетни решенија кои се однесуваа на отпадот како посочен проблем во кој применија едукативен пристап и цела бизнис кампања за стимулирање на грижата за околината. Тие понудија цел информативен систем за подобро снаоѓање во просторот, дополнет со веб страна, а понудија дизајн на производи - корпи, настрешници, клупи итн. За очекуваните резултати беа понудени квалитетни решенија, но понудија и многу повеќе од тоа - идеи за напредок и промовирање на Националниот парк Маврово како поатрактивна туристичка дестинација. 

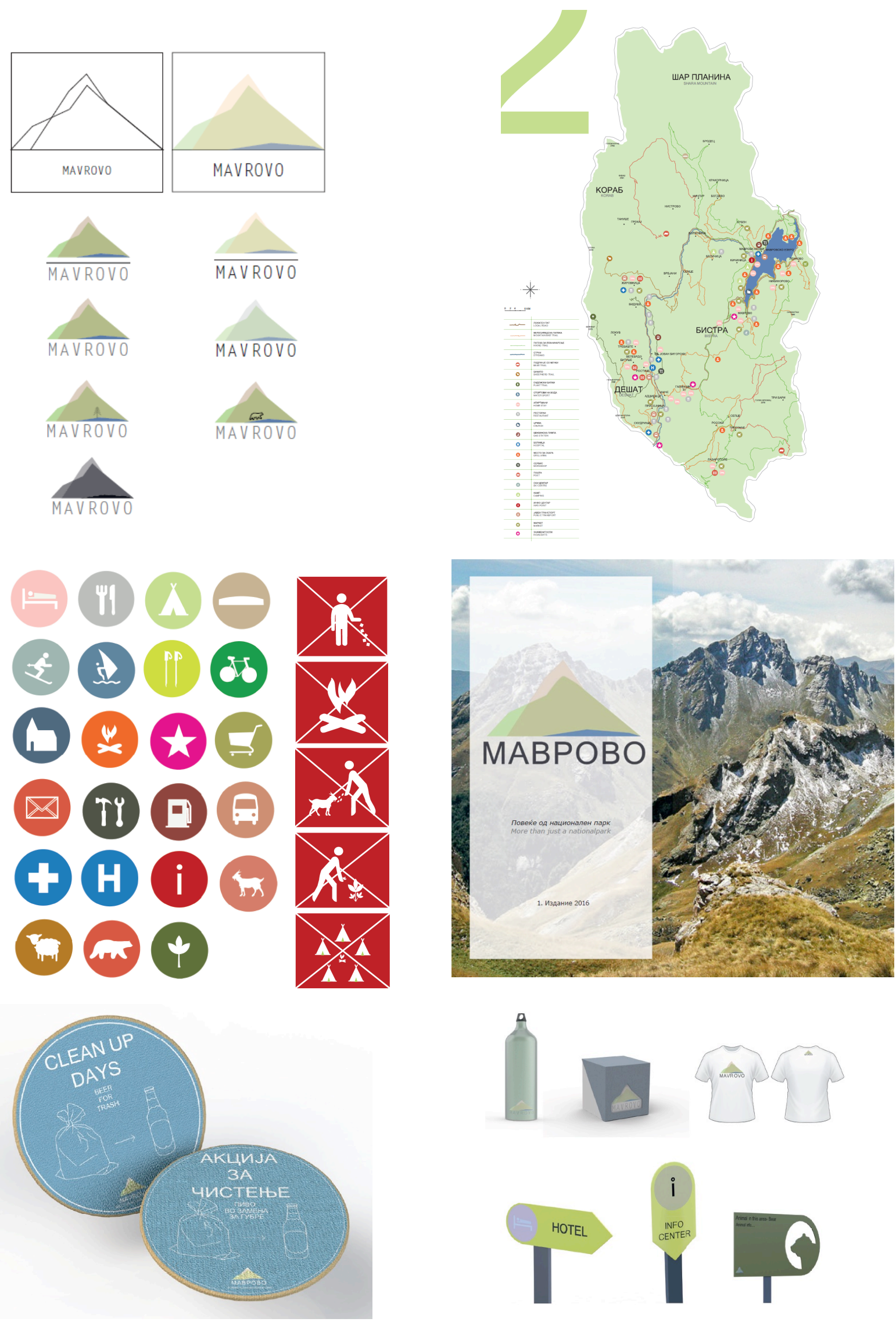

Сл. 9-15 Концепти за мавровската околина - лого, мапа, инфо икони, брошура, кампања за чистење, патокази 

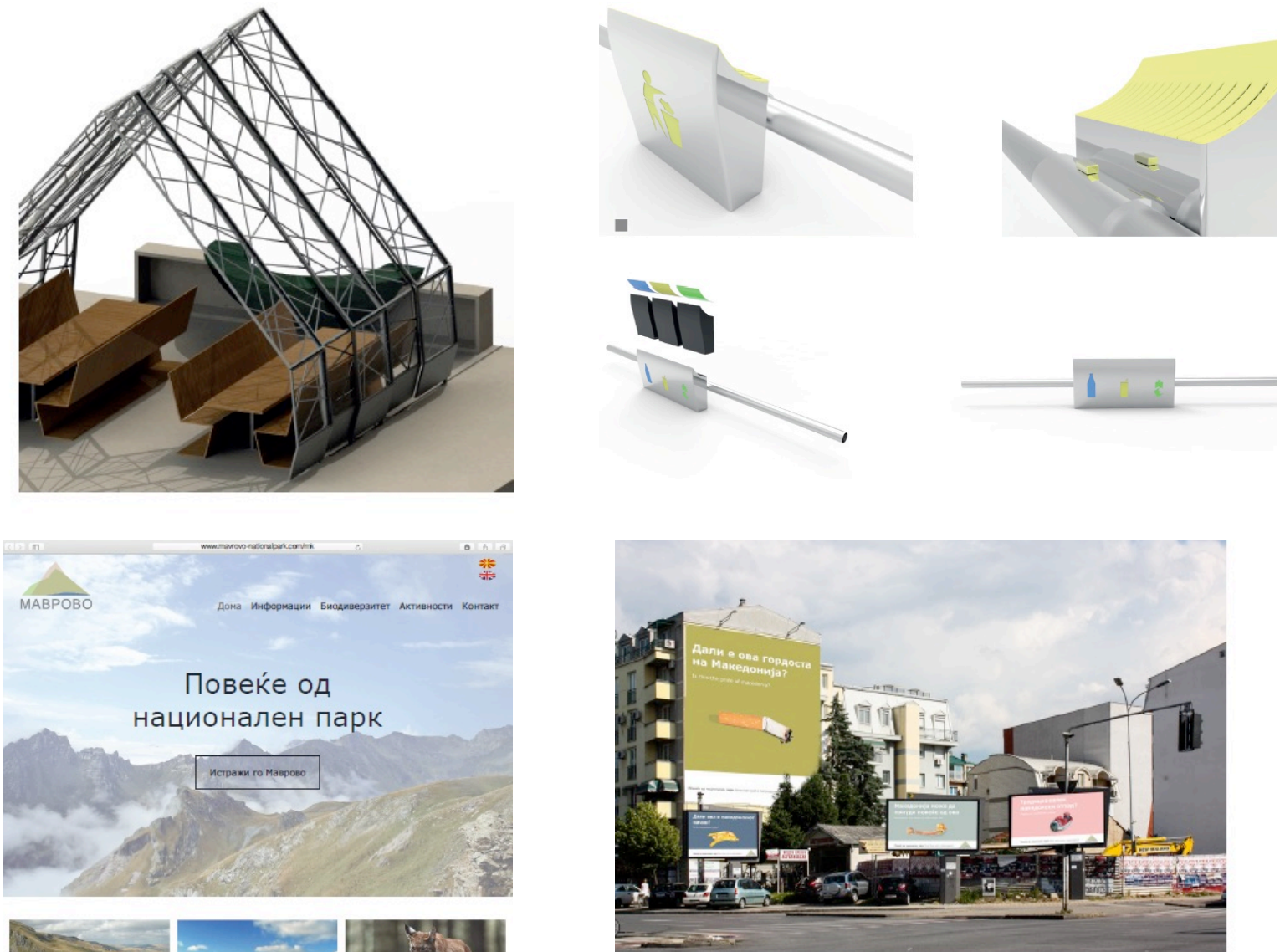
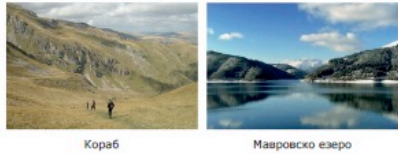

Знаменитости

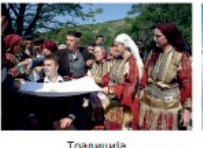

Tpannunja

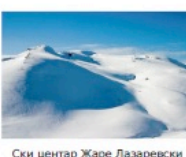

Сезони
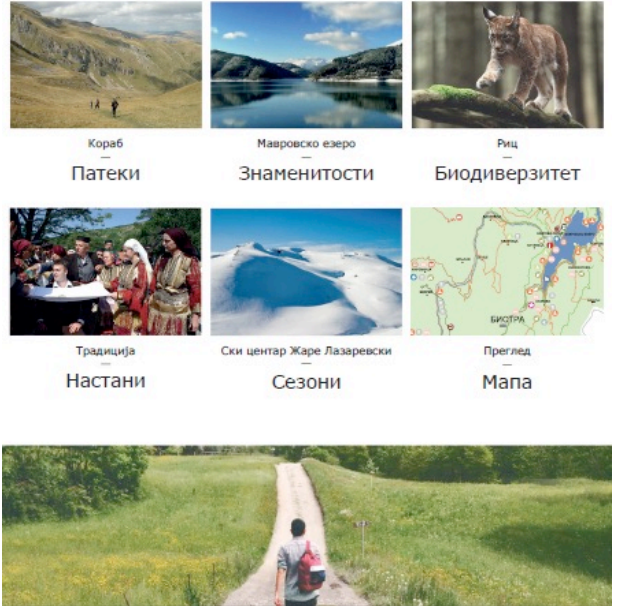
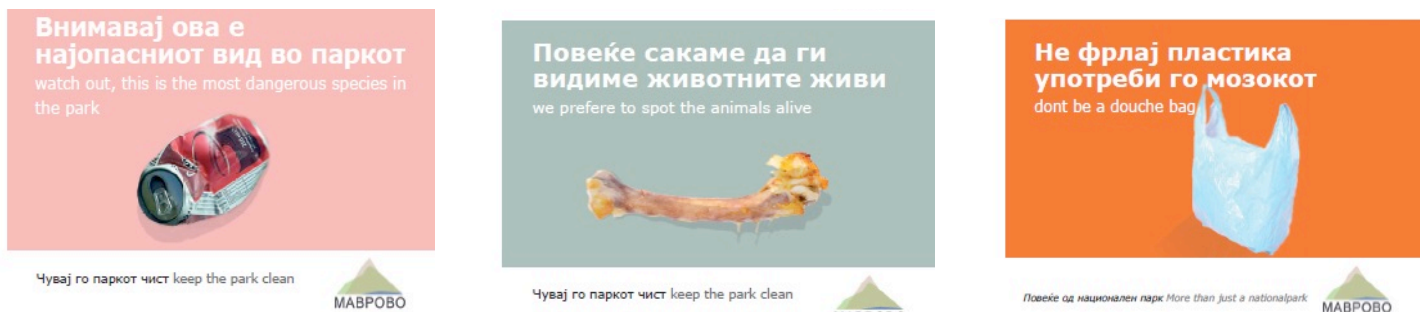

Сл. 16-22 Концепти за мавровската околина - дизајн на настрешница, клупи за одмарање, корпи за отпадоци, кампања за чиста околина преку билборди, веб сајт 


\section{Проект 2: Урбан центар за креативност и одржливост}

Наслов на бизнис проблемот предложен од Свисконтакт:

- Био-компостирање со црви

\section{Заедници поврзани со бизнис проблемот:}

- Фармери

- Фирми кои се занимаваат со био-компостирање, БИОФЛОР

\section{Опис на зададениот бизнис проблем:}

- Био-компостирање со црви сеуште не е популарно во Македонија. Го применуваат само неколку фирми кои произведуваат органски ѓубрива за одгледување на растенијата.

\section{Очекувани резултати:}

- Фирмите имаат потреба од подобри услови за манипулација со црвите и преработениот органски отпад. Тие очекуваат автоматизирање на целиот или дел од процесот со дизајн на соодветни средства за работа со кои ќе се намали напорот на вработените, а ќе се зголеми продуктивноста.

\section{Кои проблеми ги препознаа студентите?}

Студентите од овој тим реализираа соработка со професори од земјоделскиот факултет во Скопје и со компанијата БИОФЛОР која произведува органско ѓубриво преку компостирање со црвени црви. Тие најпрво го проучија процесот на разградување на органски отпад со помош на црви и микроорганизми заради добивање природно ѓубриво.

За разлика од Швајцарија, компостирањето со био-црви не е многу застапено во Македонија. Во урбаните центри во Македонија многу малку е познат тој процеспоради недостаток на информации и свест за теми од животната средина. Студентите истражуваа потенцијали за развој или каде може да пополнат празнини во полето на био-компостирање. Меѓу првите впечатоци за Скопје на студентите од Швајцарија беше проблемот со отпадоци. Се чини дека никој нема одговорност за отпадот. Ретко се наоѓаат корпи за отпадоци во градот. Отпадоците се расфрлани насекаде.

\section{Какви решенија понудија?}

Со цел да се побуди свеста во Македонија, да се сензибилизираат луѓето и да им се дадат едукативни информации за процесот, развиена е идејата за креативен простор за компостирање и урбано градинарство. Проектот „Урбан центар за креативност и одржливост“ се состоеше од неколку концепни предлози (Сл. 23-26):

- Формирање асоцијација на жители од одредена локација на градот кои ќе користат под наем кутии за компостирање заради преработка на домашниот органски отпад во употреблива органски збогатена земја за цвеќиња, со можност за комерцијална примена,

- Уредување на атрактивен простор во кој ќе се одржуваат разни културни манифестации, а еден дел од просорот ќе биде користен за чување на кутии за компостирање,

- Дизајн на лого на асоцијацијата,

- Информативни материјали за популаризација на процесот компостирање меѓу локалното население,

- Дизајн на кутија за компостирање.

\section{Колку реализираниот проект ја постигна целта на поставениот бизнис проблем?}

Студентите понудија делумно решение на поставените барања. Тие дизајнираа кутија за компостирање, што беше само еден мал дел од очекувањата на фирмата БИОФЛОР. Но, студентите понудија многу повеќе - пополаризација на постапката компостирање која би решила голем проблем во градовите - справување со органскиот отпад од домовите. 


\section{KOTA}

Kota is a public space, situated on a rooftop in the center of Skopje. Here, people can come together for events, inspiring happenings and to exchange and develop ideas by learning from each other.

The overall concept for this creative site is based on the worm town. By forming a community around the process of fertilization, people will build up the awareness for a sustainable way of life, have fun, learn and share their knowledge in a creative environment.
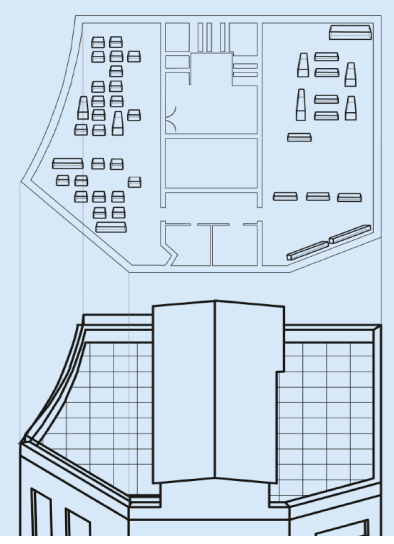

\section{WORMBOX}

The wormbox is the ideal option for vermicomposting. It hurrys up the process of making compost using worms. Worms eat a mixture of compost like: paper, food waste, green compost.

The wormbox is constructed of abs plastic. Therefore it is an optimal living place for our little friends. Worms are an optimaliving plac efficient composters and turn compost into fertile soil,
which are easily applied to plants. This box represents a perfect solution for households that will take care about the organic waste.
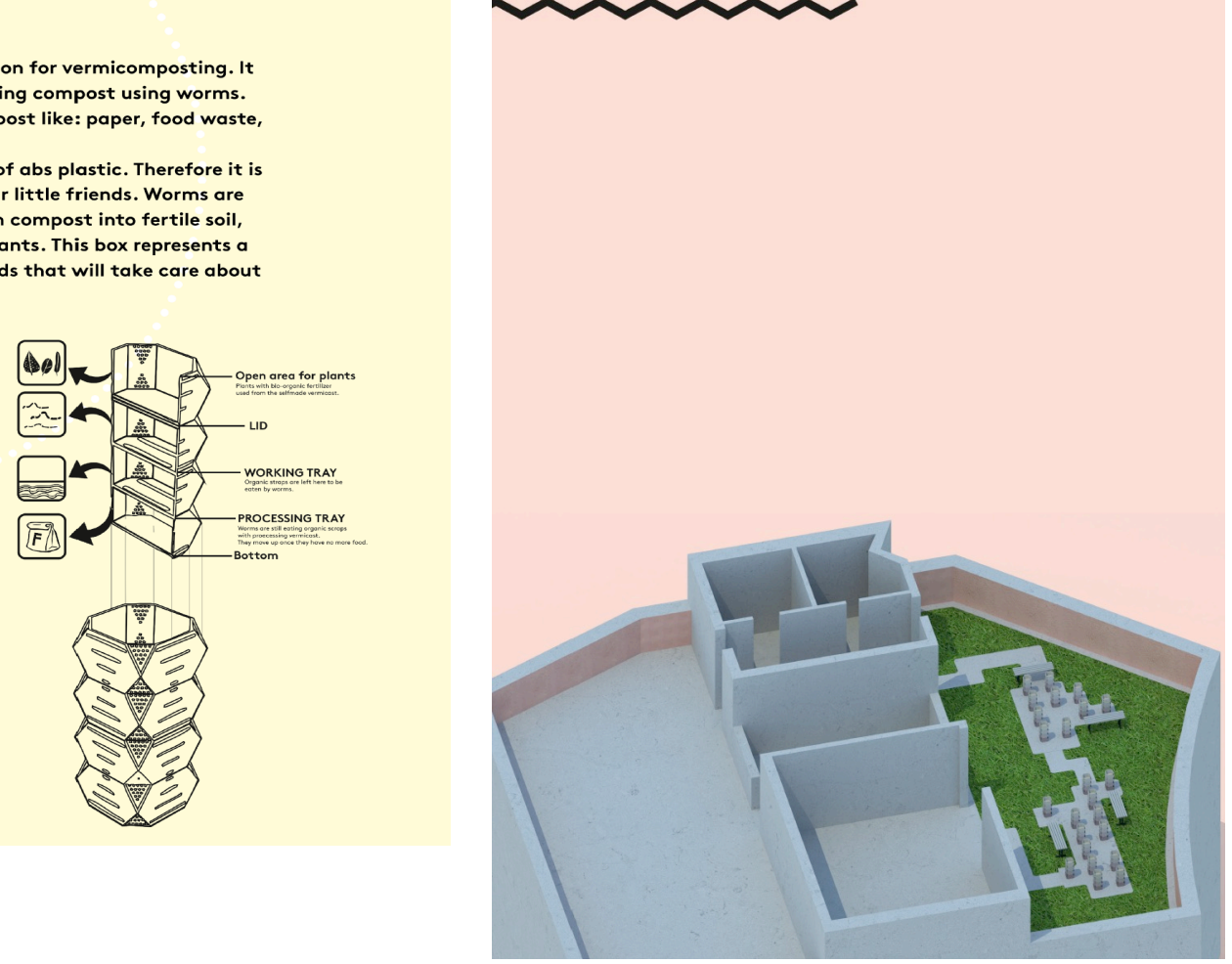

Сл. 23-26 Урбан центар за креативност и одржливост

\section{WORM TOWN}

The worm town provides the breeding ground for all

events, communication and the exchange is taking place

at the rooftop. The character of the location is defined

through the worm town installation.

This space is an inspiration and an information source,

handling with bio waste recycling and the food cycle.

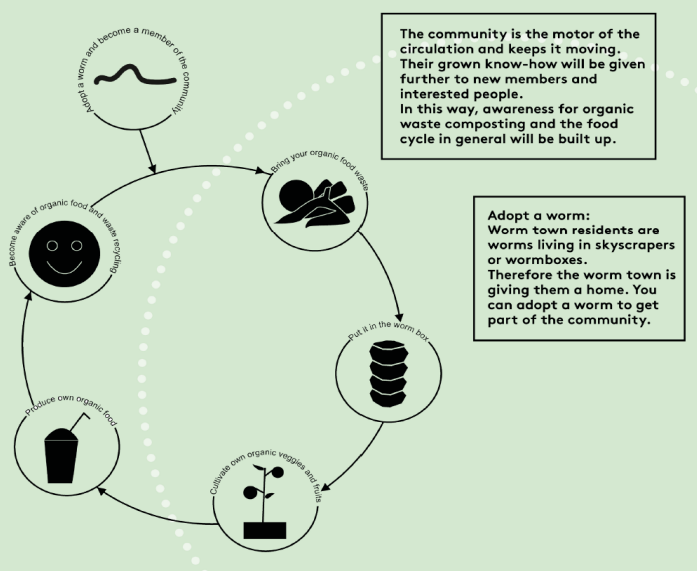

THE ROOFTOP

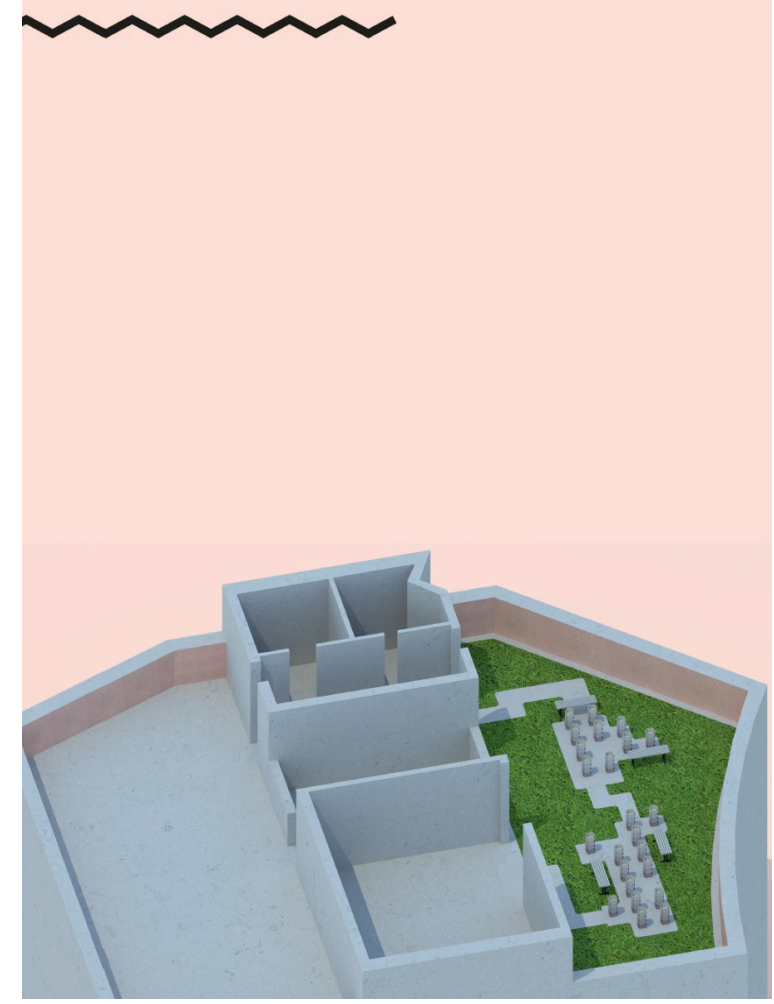




\section{Проект 3: Брендирање на природна македонска храна}

Наслов на бизнис проблемот предложен од Свисконтакт:

- Логистика за природна храна - органски овошје и зеленчик, свежи и преработени

Заедници поврзани со бизнис проблемот:

- организациите Добра Земја и Беорг,

- производители на јагоди,

- купувачи на јагоди,

- биолог од Земјоделскиот факултет

Опис на зададениот бизнис проблем:

- Македонија има одлични природни услови за одгледување органски производи, но нивната популарност не е голема ниту меѓу произведувачите, ниту меѓу купувачите.

\section{Очекувани резултати:}

- $\quad$ Неопходни се креативни решенија за пакување и логистика за органски производи со цел да се промовира и популаризира овој вид производи.

\section{Кои проблеми ги препознаа студентите?}

За реализација на овој проект студентите соработуваа со организациите Добра Земја и Беорг. Спроведоа повеке интервјуа со производители и купувачи на јагоди, производител на јагоди член на Слоу Фуд организацијата, како и со биолог од Земјоделскиот факултет. Истражувањето покажа дека има потреба од две нивоа на едукација, што беше потенцирана како главен проблем кој треба да се реши.

Првото ниво на едукацијата се однесува на земјоделските производители. Започнува со организација и планирање на производството. Тие треба да ја планираат иднината и исто така мора да комуницираат со другите земјоделци.

Другата област на едукација започнува со купувачите. Потрошувачите и трговците укажаа дека постои недостаток од информациона програма за природна и здрава храна преку која би се едуцирале сите потрошувачи свесни за нејзините бенефити. Стандардите за органска храна во Македонија не се на ниво како во другите земји. Од друга страна беше препознаен и скептицизам меѓу купувачите колку се навистина органски етикетираните органски производи. Беше заклучено дека мора да се покаже дека производителите во Македонија веќе произведуваат храна блиска до органската. Едно можно решение беше промена на дефиницијата од органска храна во природна храна, со помалку строги стандарди. Друг проблем е тоа што купувачите не знаат каде се органските продавници. Тие треба да имаат повеќе опции за пристап до органска / природна храна на лесен начин.

\section{Какви решенија понудија?}

Студентите понудија концепт линија на производи добиени од билките кои растат во македонските планини како прототипен пример за природно одгледување, фер-трговија, македонски природни ресурси и економски бенефит (Сл. 27-30). Производство на пијалок добиен од природни билки може да биде дополнителна заработка за малите фармери од планинските реони и во исто време производ со потенцијал за извоз. Проектот резултираше со:

- Идеја за пијалок и чаеви од планински билки, како природни производи,

- дизајн на опаковка,

- брендирање (лого).

Колку реализираниот проект ја постигна целта на поставениот бизнис проблем?

Понудените решенија претставуваа добар пример како да се промовираат природни прехрамбени производи, како да се направи добар дизајн на елементите за брендирање, добра опаковка. Презентираниот бизнис план покажа дека еден ваков производ би бил одличен пример за промовирање на природните (органските) производи во Македонија. 

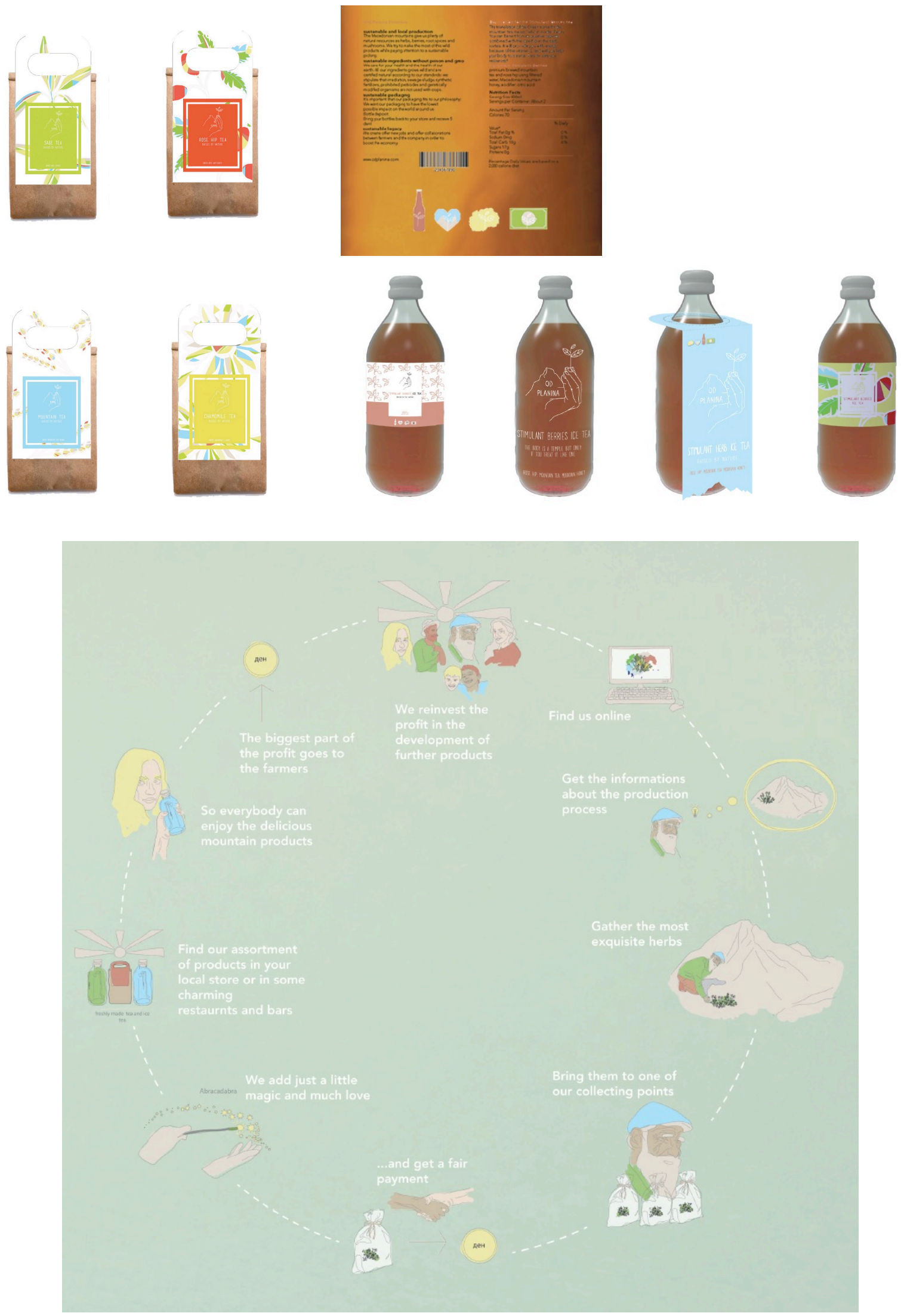

Сл. 27-30 Брендирање на природна македонска храна 


\title{
Проект 4: Нова интерпретација на македонската традиција
}

\author{
Наслов на бизнис проблемот предложен од Свисконтакт:
}

- Економско зајакнување на жените од Дебар и с. Броштица, Дебарско

Заедници поврзани со бизнис проблемот:

- „Радика Де“ - женска асоцијација од Дебар

- Регионален Бизнис Центар - Скопје

- „Обединети Креативни Жени“ од Скопје

Опис на зададениот бизнис проблем:

- Жените од Броштица произведуваат ракотворби - текстилни производи изработени со везење. Вклучените ораганизициие даваат поддршка преку поврзувањето на дизајнери со жените кои ги користат традиционалните техники на изработка на производи.

\section{Очекувани резултати:}

- $\quad$ Заради подобра продажба на современите производи неопходни се пософистицирани завршни обработки. Неопходна е можност за заедничка работа и кокреирање на вештите изработувачки на ракотворби и дизајнерите, како и подобро разбирање на потребите на пазарот.

\section{Кои проблеми ги препознаа студентите?}

Тимот од студенти имаше голем предизвик пред себе. Најпрво беше реализирана посета на неколку села во околината на Дебар каде се запознаа со вештините на локалните жени и нивните ракотворби. Постетата на Регионалниот Бизнис Центар од Скопје, Здружението Радика и асоцијацијата на жени за развој на креативните индустрии „Обединети Креативни Жени“ од Скопје, како и посетата на Националниот Музеј на Македонија беа од големо значење за собирање на сеопфатна документација во врска со македонските традиционални текстилни ракотворби.

Студентите имаа можност да се запознаат со богатата палета на текстилни ракотворби со комплексни дизајни, рачно производство на традиционална облека и накит. Денес тие ретко се користат, а претставуваат големо национално богатство. Од тука произлезе идејата да се проучат визуелните елементи на македонските традиционални текстилни производи, да се препознаат и издвојат како визуелен идентитет и да се доближат до денешниот пазар и јавноста, на еден нов и современ начин.

\section{Какви решенија понудија?}

Како резултат на ова истражување произлезе проектот „Нова интерпретација на македонската традиција" кој понуди неколку нивоа на меѓусебно поврзани креативни решенија (Сл. 31-33):

- концепт на работилница (клуб) со простор за состаноци чија цел е да се мотивираат луѓето да ја изразат сопствената креативност и интерес за ре-интерпретација на традиционални текстилни производи,

- $\quad$ два вида направи-сам производи: комплет со рамка за ткаење и кутија со печати за печатење на традиционални облици на разни текстилни производи.

Целта на понуденото креативно решение е преку постоењето на ваква клуб работилница да се понуди можност луѓето сами да стекнат искуство со печатење и ткаење, да разменуваат меѓусебно идеи, а истовремено да набавуваат материјали и литература за изработка на ракотворби со македонски традиционални мотиви.

\section{Колку реализираниот проект ја постигна целта на поставениот бизнис проблем?}

Целта не беше постигната онака како што беше замислена. Идејата да им се помогне на жените од Дебарско не беше реализирана поради недоволната можност за комуникација и ко-креирање со жените од Дебарско, пред се поради физичката оддалечонст, јазичните бариери и нејасно дефинираните очекувања. 

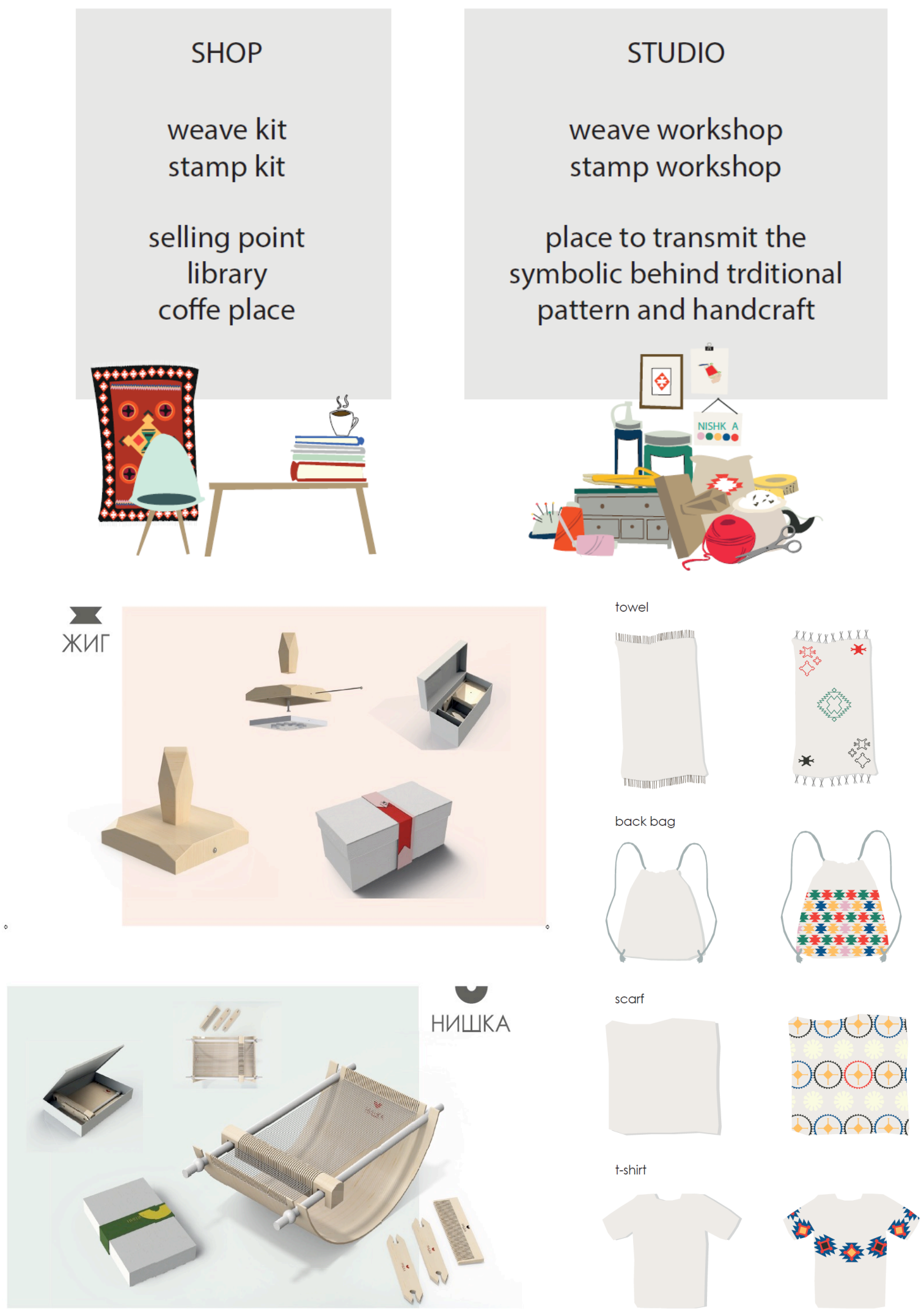

Сл. 31-33 Нова интерпретација на македонската традиција 


\section{Резиме за првата работилница}

Работилницата „Проекти за Македонија - учење едни од други“ заврши со изложба на проектите од студентите која се одржа во Сули Ан, Скопје (Сл. 34-37). Работилницата се карактеризираше со доста успешни решенија од студентите, но при реализацијата се појавија повеќе проблеми кои го одредија текот на работите и влијаеја врз целокупните резултати:

- недоволна комуникација со засегнатите заедници, фирми, поединци поради нивна незаинтересираност или скап превоз до нивните локации,

- проблеми со комуникацијата поради јазични бариери,

- процесот на ко-креирање со заедниците беше сведен на минимум, а некаде беше потполно изоставен,

- проблеми со послабата активност на студентите од Скопје, главно поради нивните обврски кон факултетот.

Спомнатите проблеми бараа редефинирањето на темите предложени од Свисконтакт, така што очекуваните резултати делумно не беа задоволени. Но, благодарение на умешноста, спретноста и познавањето на креативните техники на студентите тие понудија како решенија не само производи, брендирање, туку и креирање на нови начини на социјални активности и здружувања заради заеднички бенефит на заедниците.
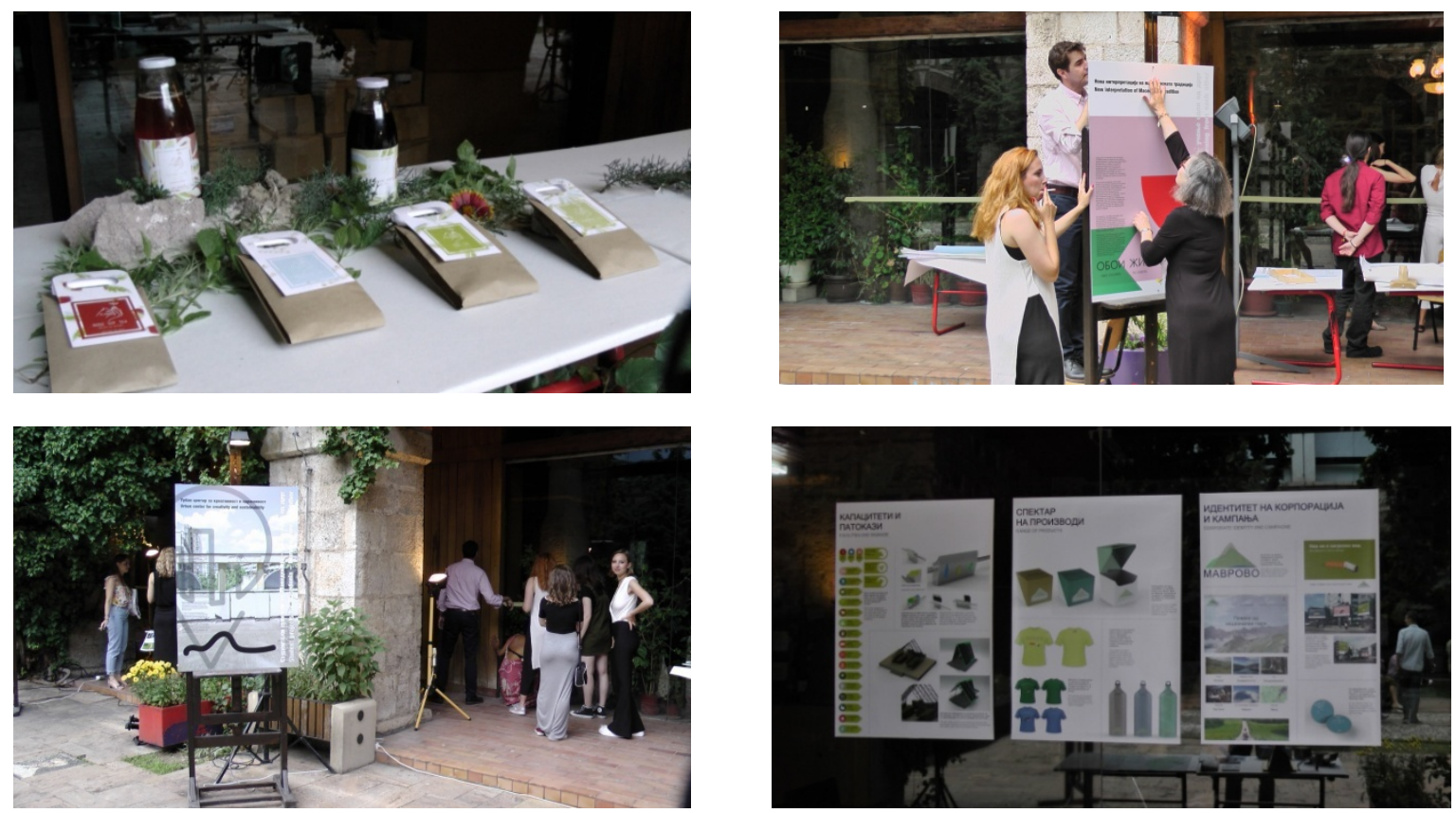

Сл. 34-37 Завршна изложба на проектите од работилницата „Проекти за Македонија - учење едни од други" 


\section{2 Работилница „Земјоделство, храна и потрошувачка“, Мачакос, Кенија, април 2017 година}

Во април 2017 година во рамките на меѓународниот проект „Дизајн со општествено влијание“ се одржа уште една меѓународна работилница во која учествуваа студенти од Машинскиот факултет во Скопје. Работилницата се одржа во Мачакос, Кенија, во период од три недели, а во неа учествуваа студенти и наставници од Цирих, Скопје и Најроби (Сл. 38-43). Студентите беа од различни дизајнерски профили: индустриски дизајн, дизајн на ентериер, моден дизајн, стил и дизајн, илустрација, дизајн на интеракција, дизајн на производи, визуелна комуникација и графички дизајн. Осум мешани тимови составени од студенти од различни култури работеа заедно: седум швајцарски студенти од Одделот за дизајн на Универзитетот за уметности во Цирих, осум македонски студенти од студиската програма Индустриски дизајн на Машинскиот факултет во Скопје и осум кениски студенти од Факултетот за архитектура и дизајн на Универзитетот во Најроби. Врз основа на негативните искуства од првите две работилници, нееднаквите работни услови за студентите во контекст на домаќини и гости, оваа работилница се одржа на неутрален терен со цел сите учесници да бидат подеднакво посветени на проектите.

Поаѓајќn од фактот дека економијата на Кенија е претежно ориентирана кон земјоделството, проектите имаа за цел да се врши истражување токму во таа област. Главните активности на невладината организација Биовижн Траст Кенија се посветени на подобрување на органското земјоделство во Кенија. Благодарение на Биовижн неколку фарми и заедници во познатата земјоделска област Мачакос беа избрани како теми за проектите. Целите не беа зададени однапред, немаше претходно дефинирани очекувања. Овој пат беше препорачано студентите да се обидат да ги вклучат членовите на заедниците како дел од тимовите, а со меѓусебна размена на искуства, преку поемпатична и попријателска комуникација, поблиску да се запознаат со нивните секојдневни проблеми.

Преку проучување на предностите, можностите, слабите и јаките страни на нивната работа, студентите успеаја да ги препознаат потенцијалите за напредок на заедниците. Заедничката работа на тимовите резултираше со интересни и необични решенија кои вклучуваа дизајн на производи, реорганизација на простор, реорганизација на 
работата, дури и предлози за организирање на локалното население во разни форми на социјално здружување заради совладување на заеднички социјални проблеми.

Искуствата во едукативните методи од претходните работилници овозможија поорганизиран пристап во подготовката на работилницата. Фактот дека беше неопходно фармерите да се интегрираат во тимовите заради кокреирање и заедничко изнаоѓање на квалитетни решенија бараше честа организирана посета на фармите. Токму тоа беше и главната причина за поголемиот успех во препознавањето на проблемите и поквалитетни решенија за нивно совладување.
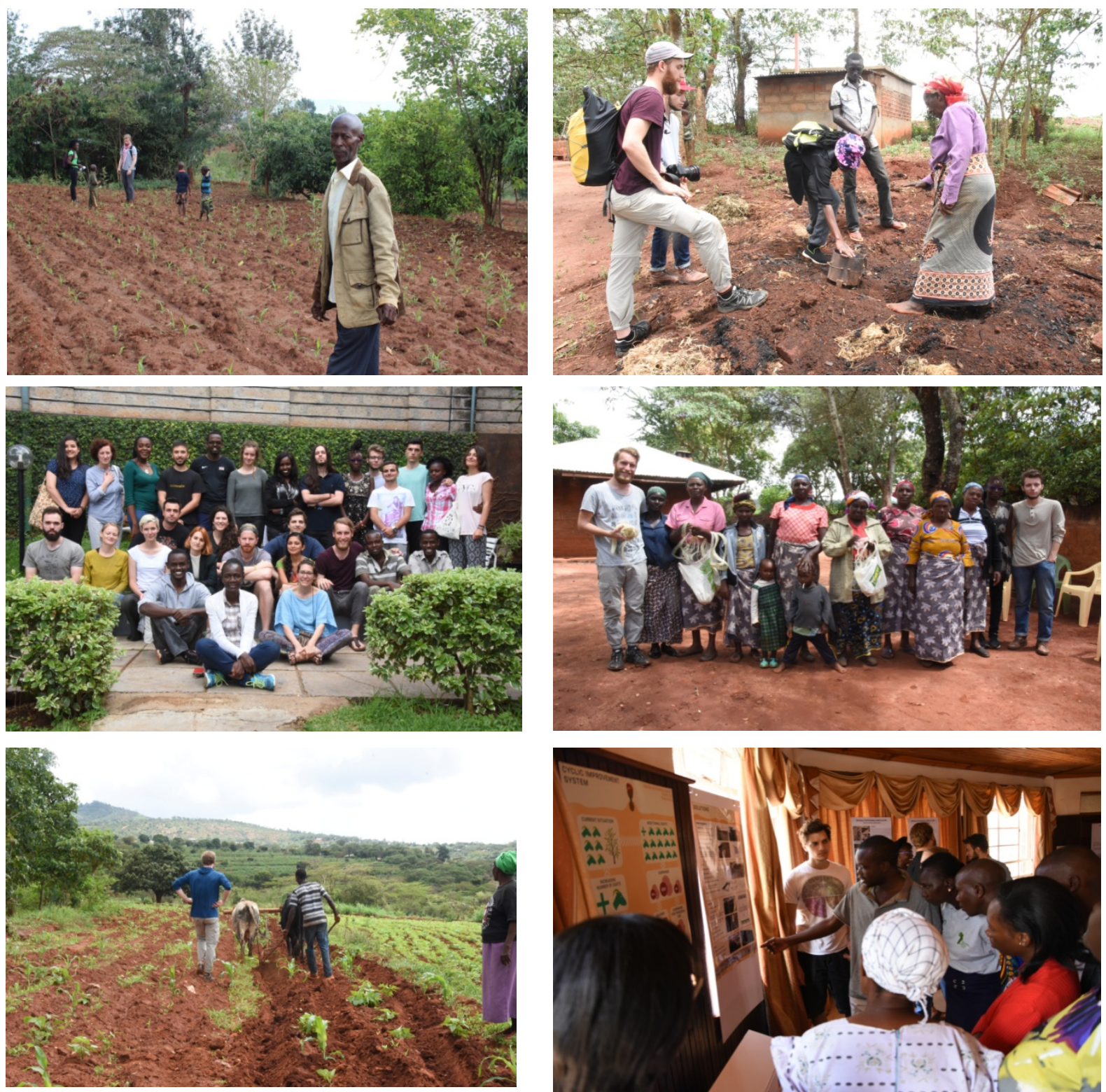

Сл. 38-43 Работилница „Земјоделство, храна и потрошувачка“, Мачакос, Кенија 


\section{Проект за Протеа Мавеу}

\section{Профил на фармерот}

- Протеа Мавеу е сопственичка на фарма во Катека Каи. Таа одгледува кози најмногу за домашна потрошувачка и само некогаш продава по неколку. Одгледува и земјоделски производи за сопствени потреби. Во рамките на нејзиниот посед таа располага со трошна куќа за живеење, нива со засадени земјоделски култури, а за испаша користи простор од поседот на нејзиниот брат, иако има неискористена површина во нејзиниот посед.

\section{Кои проблеми ги препознаа студентите?}

По извршените разговори со Протеа, тимот на студенти успеа да ги осознае нејзините главни проблеми:

- недоволно вода за козите и нивите,

- недоволно парични средства за напредок на фармата,

- незаинтересираност на нејзината ќерка за развој на фармата поради желбата за живот во градски услови.

Студентите заклучија дека фармата не е многу голема, но има поголем потенцијал од искористениот. Сопственичката не успева да извлече бенефит од изобилството на дожд за време на врнежливите сезони, ниту пак ја користи слободната земја за максимално производство, па како резултат на тоа фармата не напредува.

\section{Какви решенија понудија?}

Студентите предложија неколку решенија во врска со одржувањето и продуктивноста на фармата (Сл. 44-52).

- Со цел да се дојде до подобрување на ефикасноста на фармата, а со тоа и до поголеми приходи, беше понудена нова просторна организација на фармата како би се одвивале поефикасни активности;

- $\quad$ беше предложен нов одводен систем со олуци и базен за собирање на дождовница. Олуците за новиот одводен систем беа предвидени да се поставаат на куќата и инфраструктурата за животните, тие би имале функција да ја собираат водата од врнежите со цел нејзино складирање во базенот;

- Во склоп на новата просторна организација беа дизајнирани и нова инфраструктура, штала за кози, како и ограда за заштита од предатори;

- предлог план за развој на фармата.
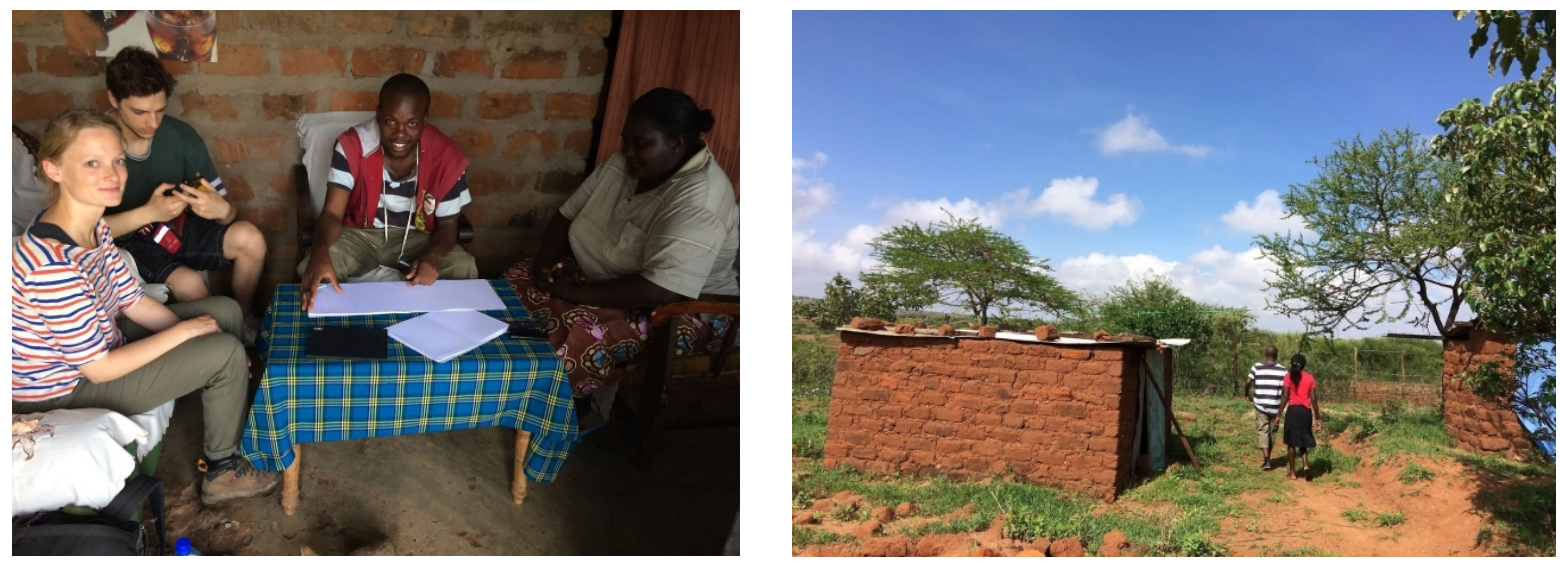


\section{FARMER`S PROFILE}

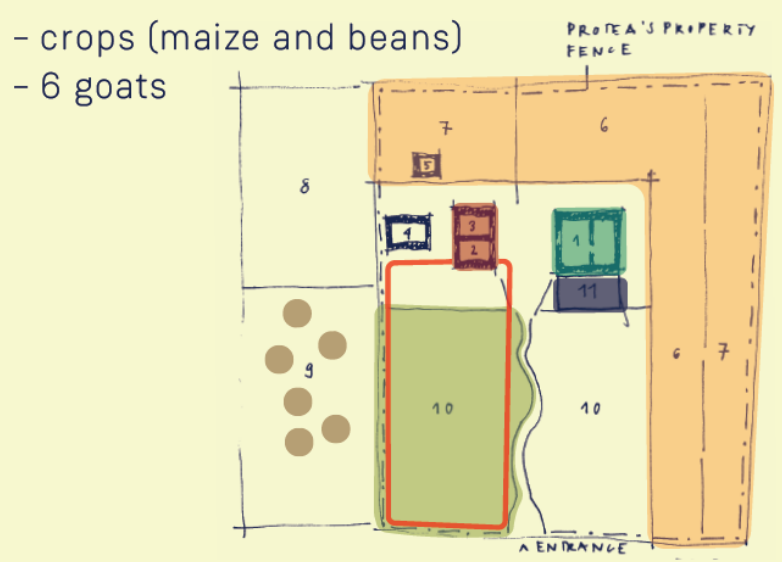

MAIN HOUSE GUTTERS

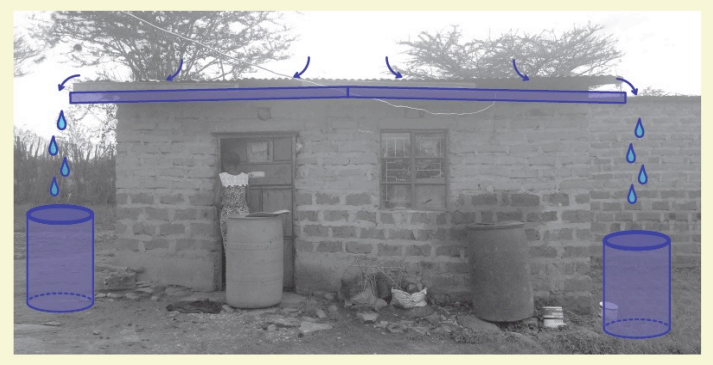

GOAT PEN ROOF
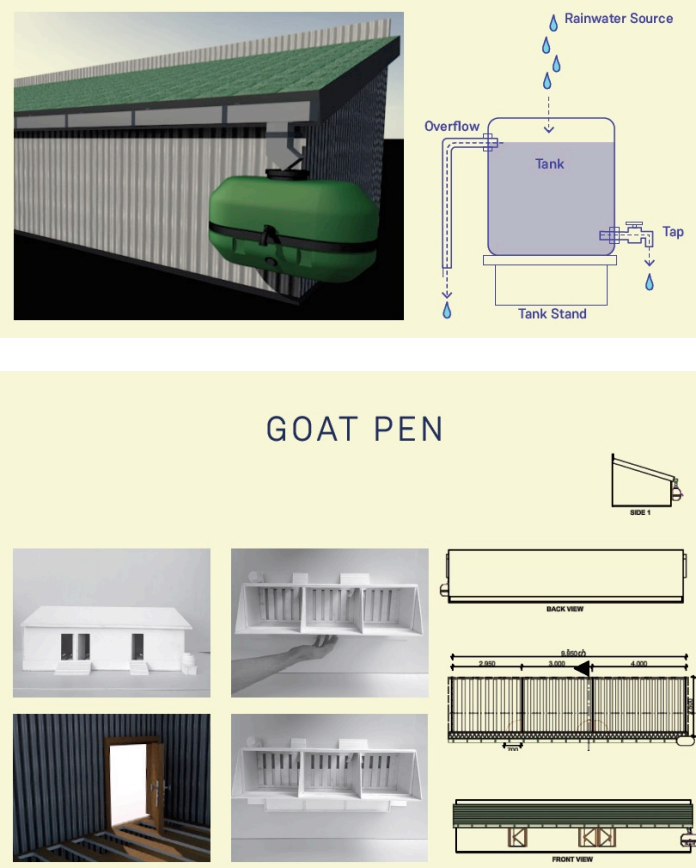

$$
\text { GOAT PEN }
$$

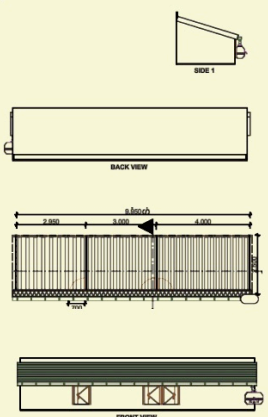

WATER COLLECTION POOL

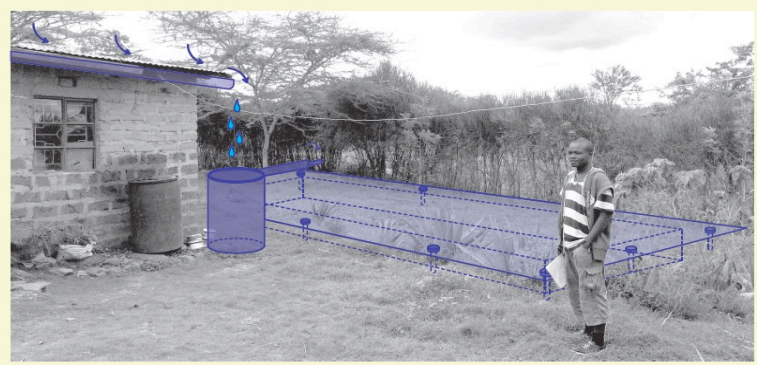

FENCE

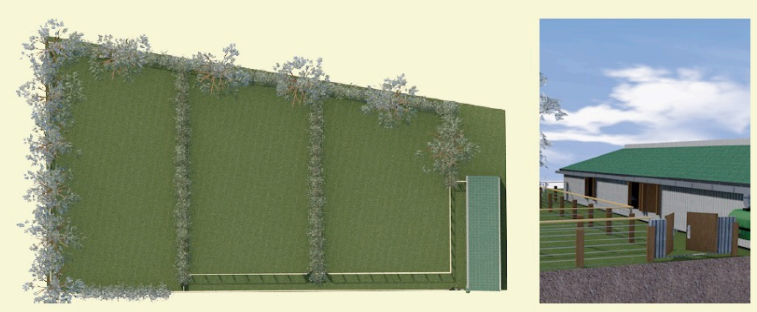

CYCLE IMPROVEMENT SYSTEM
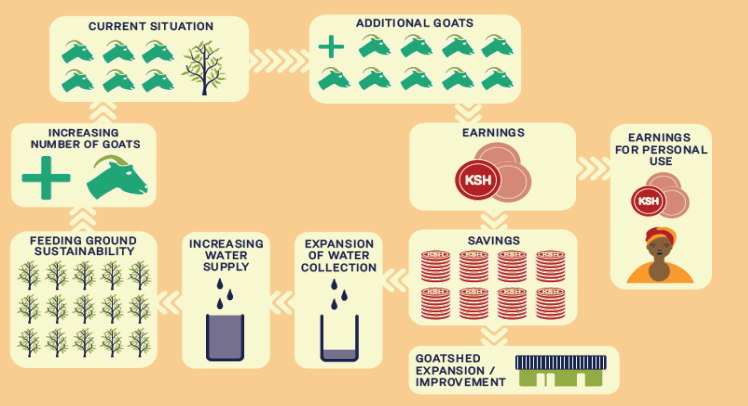

Сл. 44-52 Проект за Протеа Мавеу 


\section{Проект за Магдалена Муаса}

\section{Профил на фармерот}

Магдалена Муаса е егзистенционален фармер во Катека Каи и лидер на младинската група во Биовижн Африка Траст со името "Кукена кува Суа". Таа одгледува зајаци, кокошки и кози приоритетно за домашна потрошувачка.

\section{Кои проблеми ги препознаа студентите?}

Магдалена има за цел да обезбеди погодна животна средина за нејзините зајаци, нивна добросостојба, како и да ја зголеми продуктивноста. Меѓутоа кафезот кој таа го поседува во моментот е премал и поради тоа зајаците се борат и повредуваат меѓусебно, а тоа ја попречува нејзината цел за одгледување на повеќе зајаци.

Вториот проблем е недостигот на парични средства за изградба на нов кафез.

\section{Какви решенија понудија?}

Студентите ја препознаа предноста што Магдалена Муаса беше члена на младинска група. Тие ја истакнаа оваа предност и можноста за меѓусебна помош заради бенефит на сите членови. Беше предложено да работат заедно во изградба на дизајнираната инфраструктура за животните, како почеток во фармата на Магдалена Муса за демонстрација, а подоцна низ соседството со цел да се создаде кохезија во заедницата (Сл. 53-56).

Студентите изработија:

- предлог концепт дизајн на кафез за зајаци;

- упатство за изработка на кафезот;

- предлог план за ширење на активностите на младинската група во заедницата.

KUKENA KWA SUA COLLABORATIVE SYSTEM
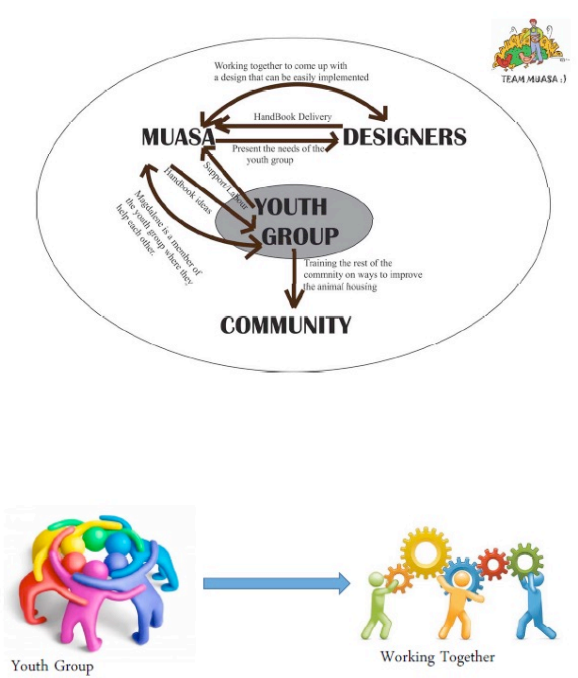

with Handbook
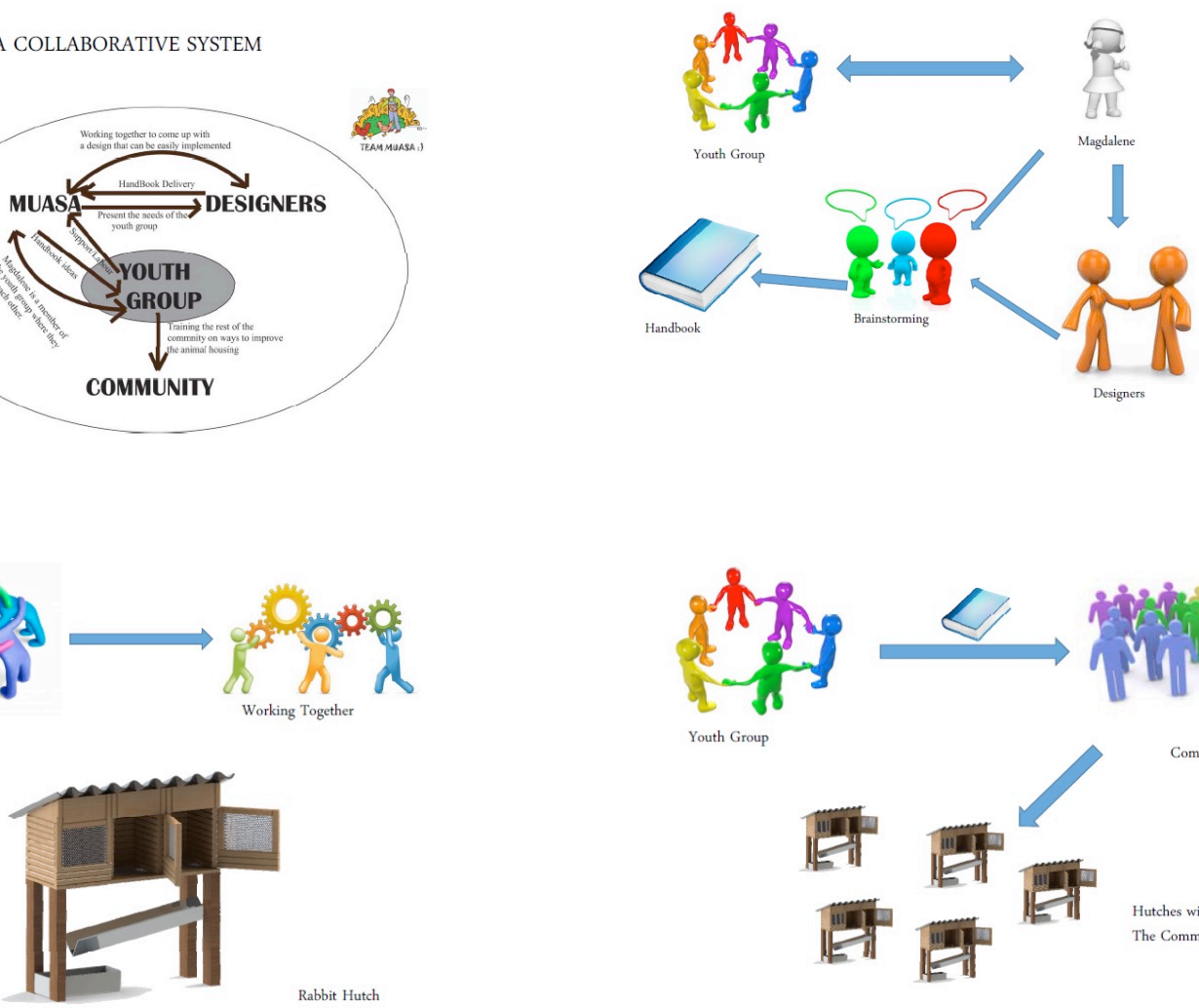
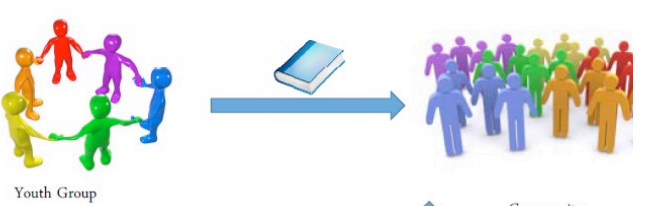

Сл. 53-56 Проект за Магдалена Муаса 


\section{Проект за Вилсон Ндето}

\section{Профил на фармерот}

Вилсон Ндето е 67-годишен фармер кој одгледува овошје како авокадо, манго и папаја за продажба. Иако поседува голема површина на одгледлива почва, тој нема капацитет да ја искористи бидејќи во земјоделието му помага само неговата жена, а неговите деца преферираат да работат во градот, а не на фармата.

\section{Кои проблеми ги препознаа студентите?}

Главен проблем на Вилсон е да обезбеди помош за работа на фармата и да обезбеди пласман за неговите производи кои му остануваат, а не му требаат.

\section{Какви решенија понудија?}

Можностите за решение на неговите проблеми студентите ги препознаа во близината на основното училиште во Макуени. Тие предложија поврзување на училиштето со фармата на Вилсон како би се воделе практични курсеви за земјоделство, а учениците би можеле да видат како се одвива органското земјоделство. Студентите дизајнираа т.н. земјоделски клуб кој има две примарни цели со кои би се решиле препознаените проблеми (Сл. 57-60):

- Првата цел на земјоделскиот клуб е да им помогне на повозрасните земјоделци да продолжат со обработка на нивното земјиште, а со тоа и да си обезбедат доволно храна за нив и нивното семејство.

- Втората цел е да се направи земјоделството попопуларно за младите со цел тие да се мотивираат да ги превземат фармите од нивните родители.
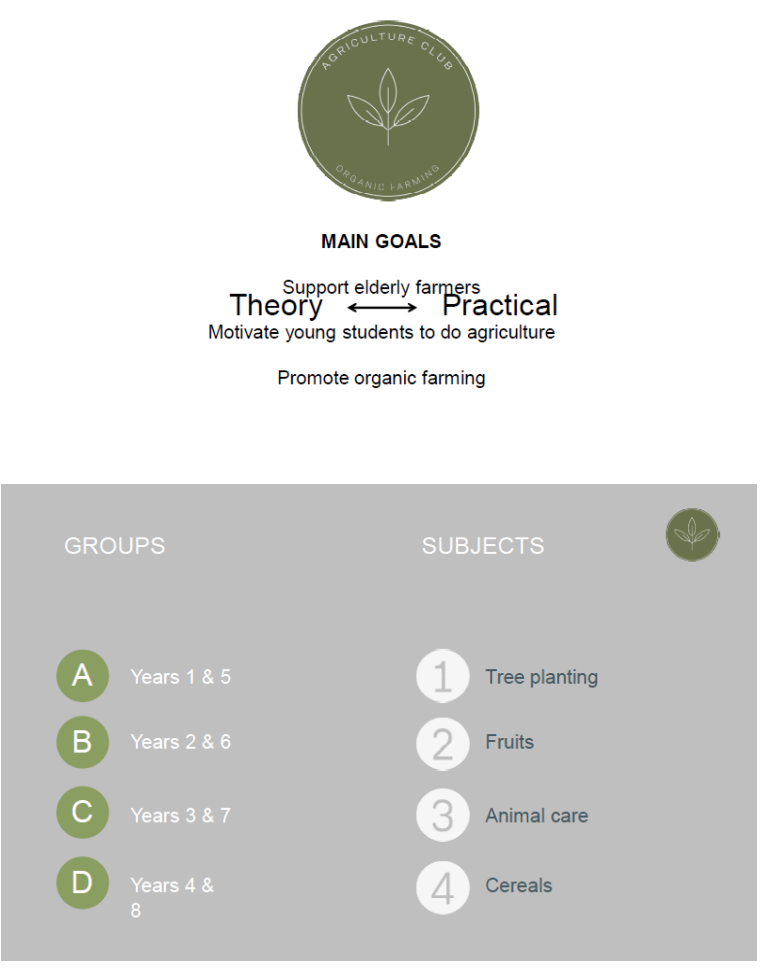
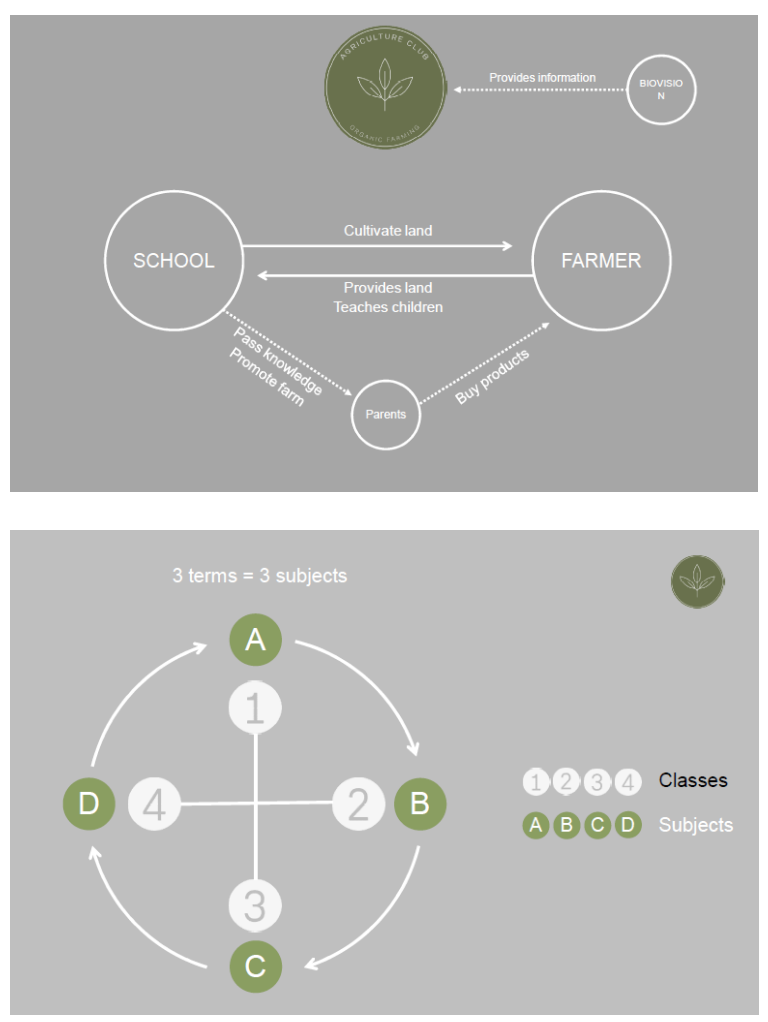

Сл. 57-60 Проект за Вилсон Ндето 


\section{Проект за Рафаел Мбуви}

\section{Профил на фармерот}

Рафаел Мбуви е комерцијален фармер од Катека Каи, Мачакос. Тој примарно произведува зеленчук како кељ, домати, капсикум пиперки и кромид. Неговото земјиште од дваесет хектари со различни овошја и зеленчук се протега покрај река од каде што користи вода за наводнување. Мбуви покрај земјиштето со житни култури поседува и два бика, една крава и теле, седум кози и три зајаци. Производите од животински отпад ги користи како ѓубриво на фармата.

\section{Кои проблеми ги препознаа студентите?}

Покрај огромните ресурси на фармата, студентите забележаа и неколку големи проблеми: површински отпад, ерозија на почвата, термити, трошоци за наводнување на земјиштето итн. Капацитетот на неговата фарма не е целосно искористен, а и трошоците за производство, кои најмногу се за пестициди и ѓубрива, се преголеми.

\section{Какви решенија понудија?}

Решението на овие проблеми беше развивање на одржлив систем за неговата фарма со подобрување на условите за зајаците, а со тоа и зголемување на нивниот број. Тоа би овозможило експоненцијален раст на фармата: повеќе вода за одгледување, прибирање органско ѓубриво, поздрави култури, продолжен период на жетва и приход за инвестирање. Системот беше надополнет со дизајнирање на прирачник за одгледување зајаци и модуларен кафез со опрема за собирање на отпадот како природно ѓубриво и пестициди (за сопствени потреби, но и за обезбедување дополнителен приход со продажба) (Сл. 61-64).
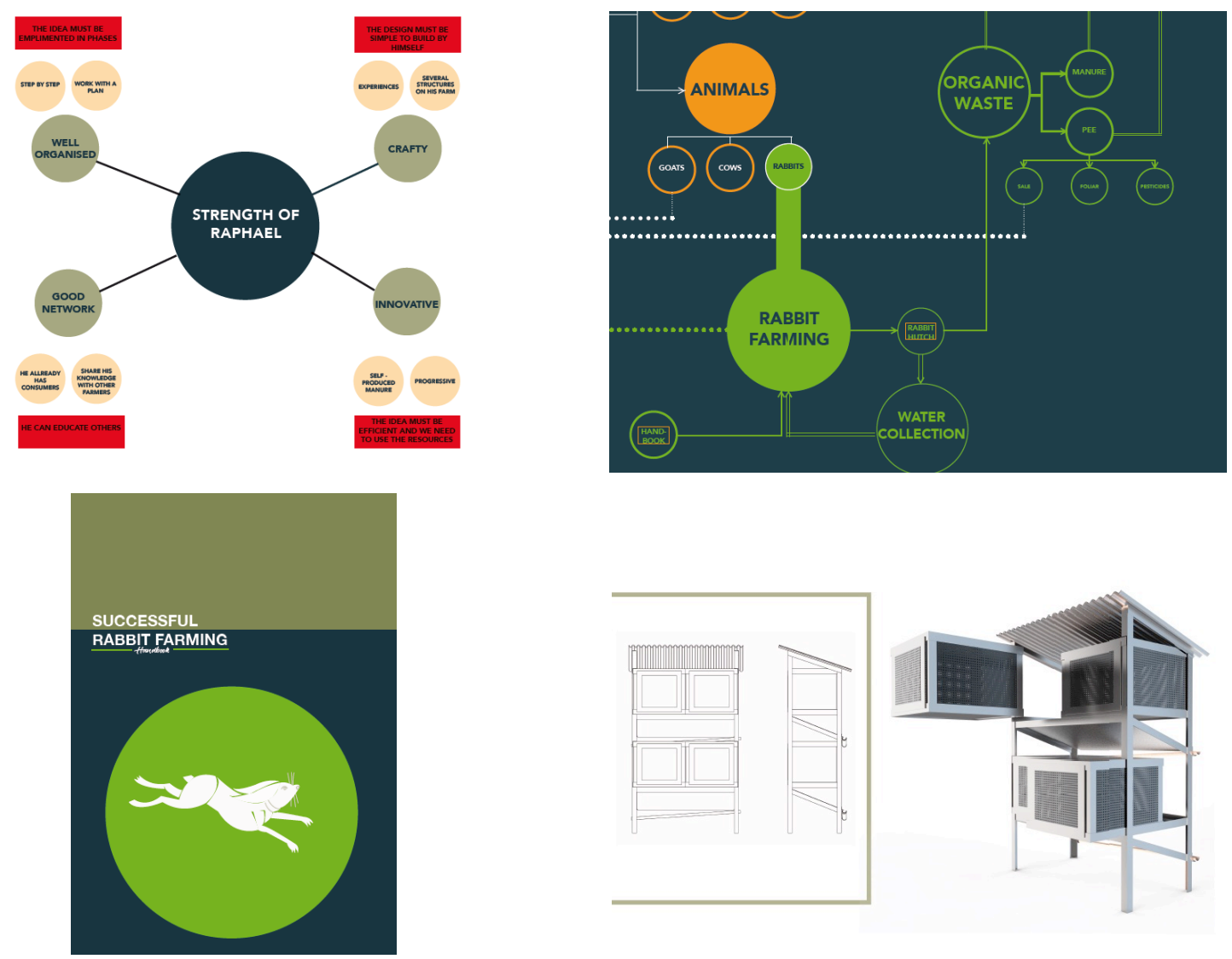

Сл. 61-64 Проект за Рафаел Мбуви 


\section{Проект за Кевин Ваита}

\section{Профил на фармерот}

Семејството на Кевин се занимава со одгледување на пченка, грав, спанаќ, маниока, во најголем дел за домашна потрошувачка. Кевин се бави со одгледување живина, размножување и продажба на пилиња.

\section{Кои проблеми ги препознаа студентите?}

Кевин е многу успешен фармер, но неговите амбиции се многу поголеми од постигнувањата. Има желба да биде обучувач за одгледување на живина, но од друга страна има егзистенцијални и финансиски проблеми кои не му дозволуваат да се посвети на рализацијата на оваа амбиција.

\section{Какви решенија понудија?}

Студентите и Кевин диксутираа за неговите проблеми и разработуваа нови идеи за тоа како да се подобри бизнисот, а притоа да се задржи моменталниот циклус на производство на живина. Беше претставен модел на одржлив систем за производи и услуги. За потребите на амбицијата на Кевин за обучување на другите земјоделци како да одгледуваат кокошки беше дизајнирана потребната опрема и брошура за настава. Дополнително, студентите предложија уште едно дополнително решение искористување на отпадот од живината за производство на брикети кои би можеле да обезбедат вреден приход за Кевин (Сл. 65-70).
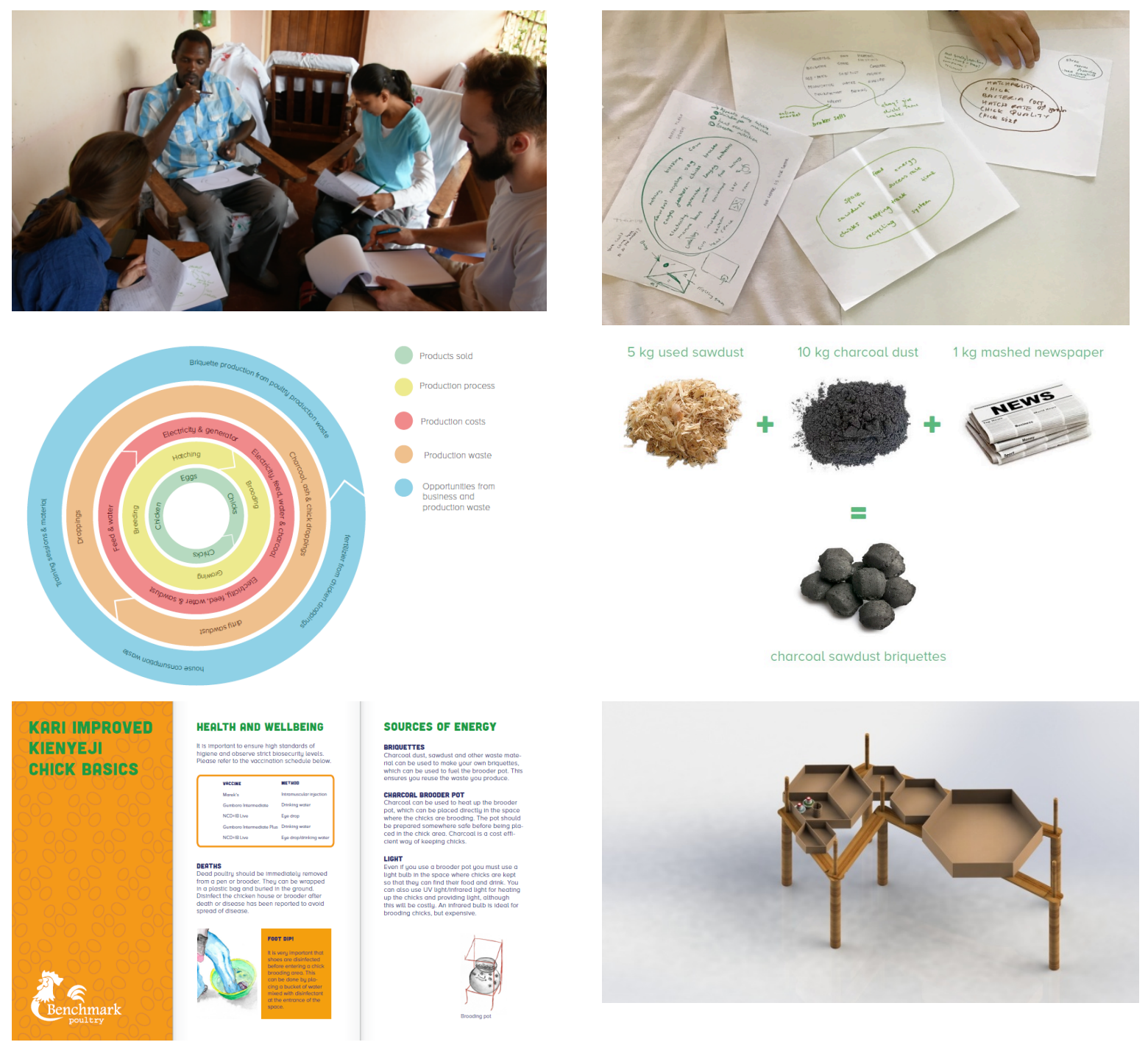

Сл. 65-70 Проект за Кевин Ваита 


\section{Проект за Џозеф Мбити}

\section{Профил на фармерот}

Џозеф Мбити е земјоделец, обучувач и студент за органско земјоделство. Тој поседува фарма со разновидни овошја, зеленчук, живина и стока, а покрај тоа има и резервоари за вода, складиште за храна и расадник.

\section{Кои проблеми ги препознаа студентите?}

Проблемот на Џозеф Мбити е како во иднина неговата фарма да добие редовен и повисок приход. Тој сака неговата фарма да ја претвори во агротуристички центар, а предизвикот е во тоа што таа визија бара вложување на многу пари за да се овозможи потребната инфраструктура

\section{Какви решенија понудија?}

Студентите, заедно со Џозеф и неговото семејство, конечно го разработија концептот за развојна стратегија во три фази. Во првата фаза неопходно е подобрување на фармата за кокошки која би донела поголем профит. Тоа би значело можност за инвестирање во втората фаза во која би се продолжило со подобрување на другите дејности, кои пак би довеле до нов поголем профи. На тој начин постепено, во третата фаза би можела да се реализира последната цел - фабрика за манго.

Освен концептот за развојна стратегија студентите понудија и дизајн на модуларен кафез за кокошки кој би имал можност за постепено доградување во чекор со растот на приходите и можностите за инвестирање (Сл. 71-74).

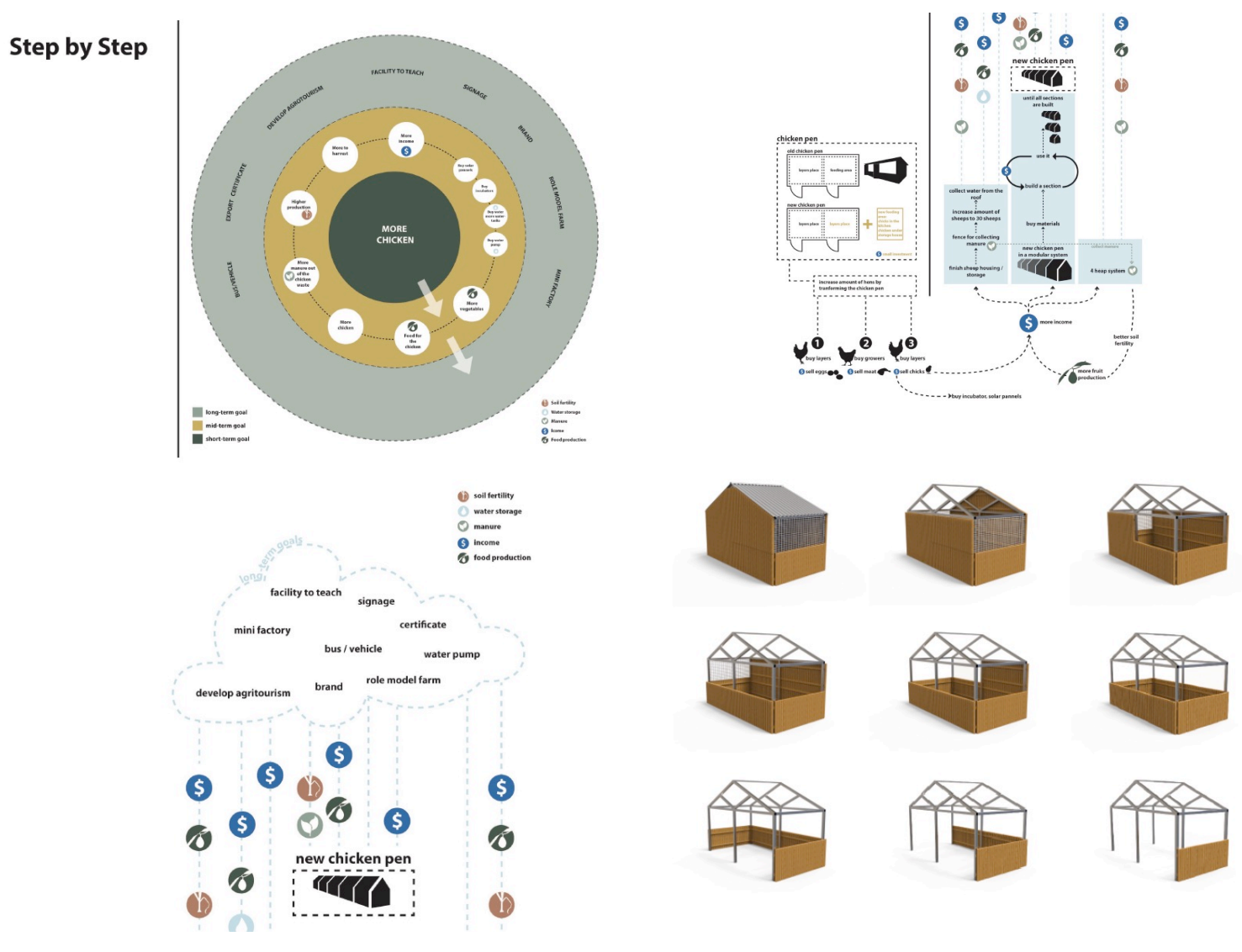

Сл. 71-74 Проект за Џозев Мбити 


\section{Проект за Ребека Муинди}

\section{Профил на фармерот}

Ребека е постар сопственик на фарма која се обидува да обезбеди храна и приход за своето семејство. Таа главно произведува пченка и грав, а исто така и избрани плодови како манго, папава и авокадо на нејзината фарма. Ребека пак, од друга страна е член и Раководител на локалното здружение на жените.

\section{Кои проблеми ги препознаа студентите?}

Покрај големината на нејзината фарма и неможноста таа сама да ја одржува и менаџира, студентите препознаа и други проблеми: ерозија на почвата, недостаток на вода, енергија и други непогоди.

\section{Какви решенија понудија?}

Студентите пристапија на решавање на овој проблем врз основа на големината на фармата и општествениот стекнат капитал на Ребека, понудија решение со кое фармата ќе стане самоодржлива со инволвирање на членовите од заедницата. Тие би работеле на фармата во замена за стекнување знаење, преку создавање на одржлив социјален систем кој ќе биде од корист за нејзината фамилија и локалната заедница (Сл. 75-78).

\section{IDEATION social system}

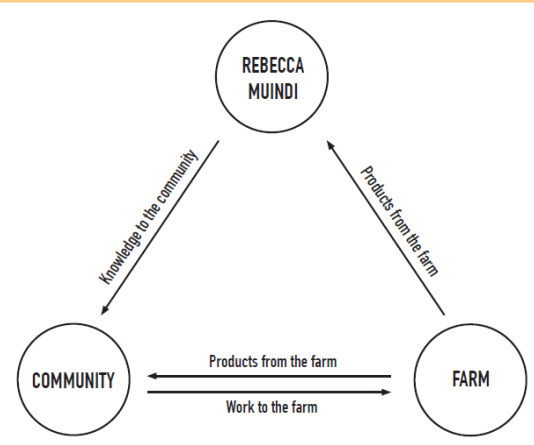

CO-CREATION team-UP

\section{CO-CREATION group work}

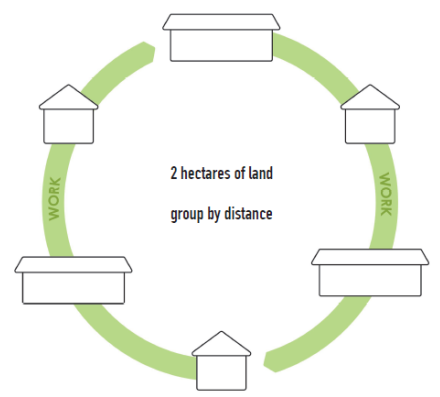

CO-CREATION marketing

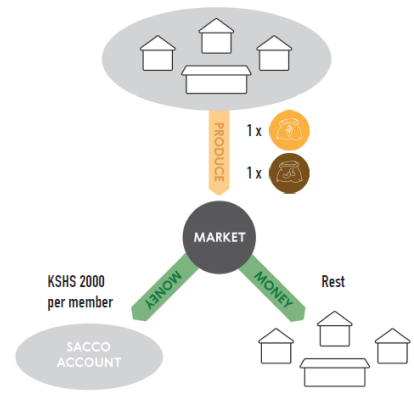

Сл. 75-78 Проект за Ребека Муинди 


\section{Проект за Ресурсниот центар Мачакос}

\section{Профил на Ресурсниот Центар}

Главната задача на Ресурсниот центар Мачакос е дистрибуирање информации до земјоделците. Најчесто тоа се помали и средни земјоделци кои се добро поврзани меѓу себе. Тој е поддржан и управуван од невладината организација Биовижн Африка Траст.

\section{Кои проблеми ги препознаа студентите?}

Преку спроведените интервјуа со членовите на овој центар студентите ги препознаа проблемите на Ресурсниот центар:

- недоволната примена на знаењето кое центарот им го пренесува на земјоделците,

- потешкотии при продавање на органски производи по повисоки цени,

- стареење на земјоделците (нивната просечна возраст е 51 година) и

- младината не е доволно информирана за органски производи.

\section{Какви решенија понудија?}

Соработка помеѓу студентите и персоналот на Ресурсниот центар Мачакос и фармерите резултираше со ставот дека е доста важно да се зголеми побарувачката на органски производи и да се применуваат знаењата кои земјоделците ги добиваат од Ресурсниот центар Мачакос. Беа предложни решенија за обезбедување „видливост“ на пазарот преку (Сл. 79-82):

- ознаки,

- информативни постери,

- кампања за подигнување на свеста,

- сертификација и создавање на одбор за комуникација на фармерите.
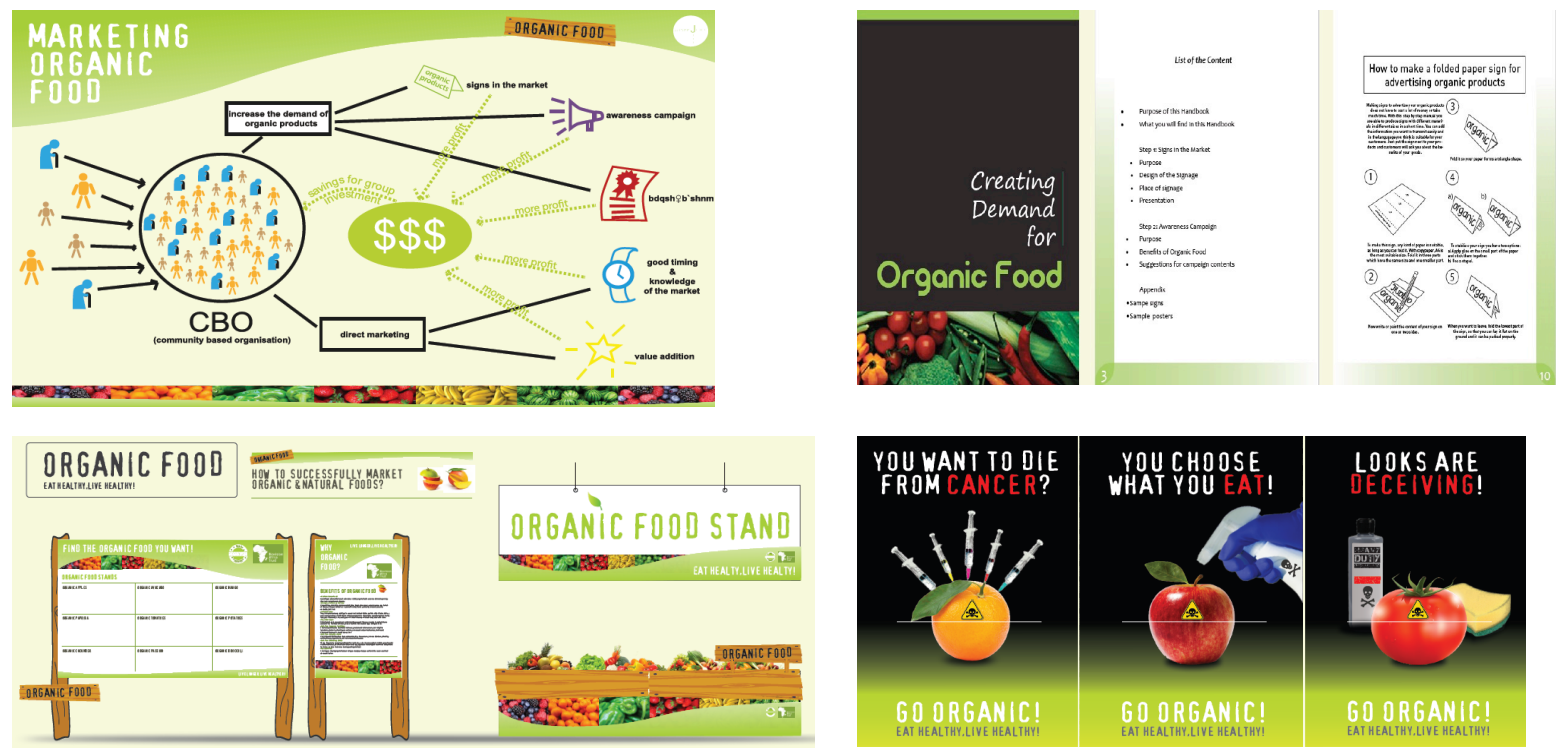

Сл. 79-82 Проект за Ресурсниот центар Мачакос 


\section{Резиме за работилницата „Земјоделие, храна и потрошувачка“}

Работилницата „Земјоделие, храна и потрошувачка“ заврши со изложба и јавна презентација на проектите пред членовите на заедниците и фармите, како и членови на Биовижн Трас Кенија, Факултетот за дизајн и архитектура од Најроби и други поканети гости (Сл. 83-86).

На крајот на тринеделната работа задоволството на сите учесници беше големо. Беше видливо дека искуствата од претходните работилници придонесоа за појасно осознавање на процеот на дизајн во проектите со општествено влијание и негова покомплетна и поефикасна примена. Стана сосема јасно дека процесот на кокреирање со членовите на вклучените заедници е од пресудно значење за донесување подобри решенија. Искуствата од обете страни се неопходни за потемелно осознавање на проблемите, а оттука и потемелно решавање на истите. Од друга страна, улогата на невладината организација Биовижн беше од пресудно значење за воспоставување на врските помеѓу добро избрани претставници на заедницата на фармери од областа Мачакос.

Резултатите од проектите не претставуваа моментално решавање на проблемите на заедниците. Но, преку заедничката работа на проектите тие научија нови техники на размислување за справување со секојдневните проблеми на фармите. Од друга страна, добија идеи за подобрување на нивните моментални состојби, кои можеби имаат иднина доколку се најде начин за нивна реализација. Проектите резултираа со голем број разновидни креативни решенија:

- социјални здружувања за взаемно помагање

- организација на работата на фармите

- организација на просторот на фармите заради подобра ефикасност

- дизајн на подобри кафези / штали за одгледување на зајаци, живина, добиток

- дизајн на информативни брошури 

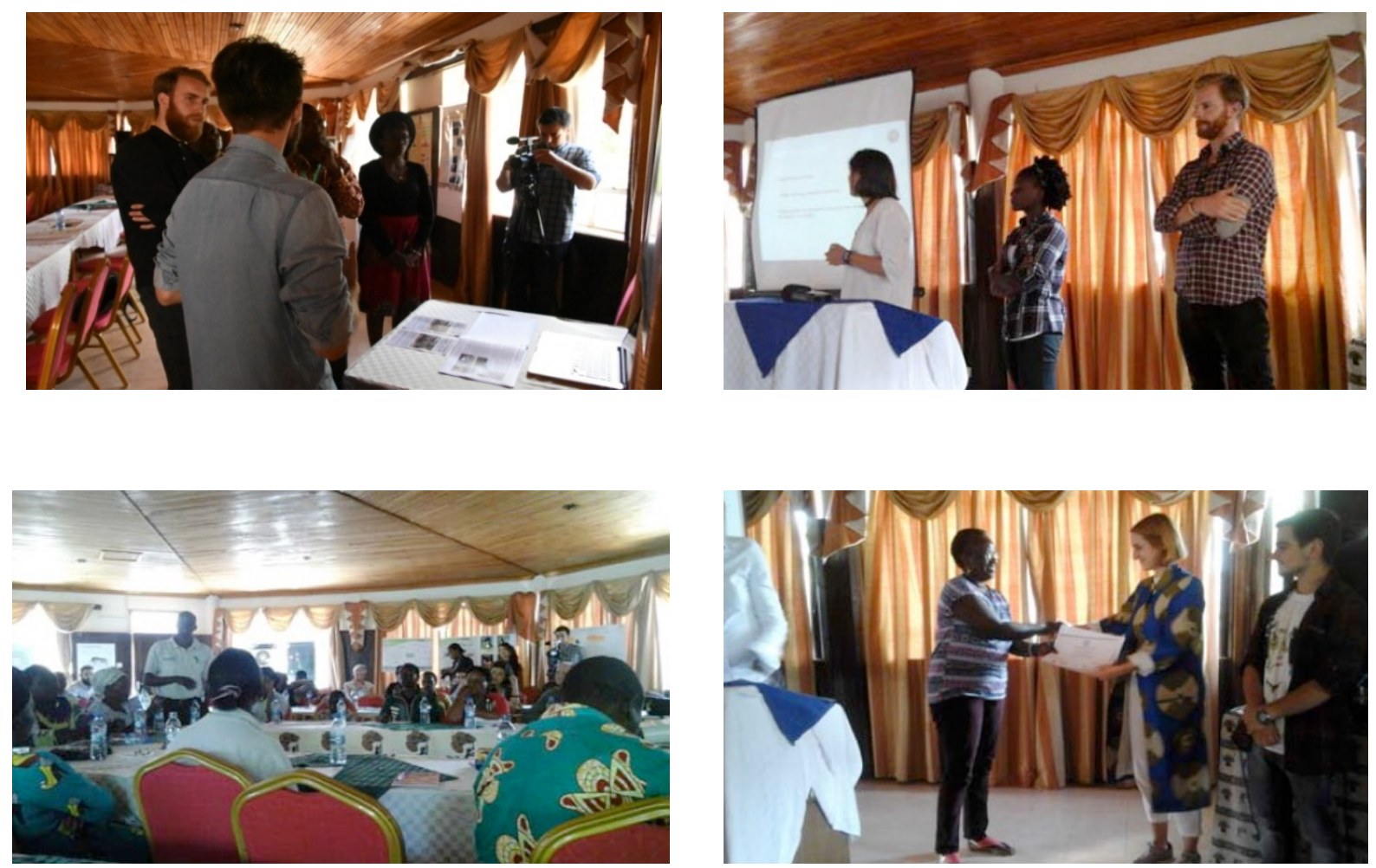

Сл. 83-86 Завршна презентација и изложба на резултатите

\section{3 Анализа на резултатите од работилниците}

По завршувањето на двете работилници во кои учествуваа студентите од Машинскиот факултет беше извршена анализа на резултатите од реализираните проекти со цел да се извлечат корисни генерални заклучоци за суштината на проектите од областа на дизајн со општествено влијание (Таб. 2, Таб 3, Таб. 4). Анализата е извршена од неколку аспекти кои треба да дадат одговор на повеќе прашања во врска со реализацијата на дизајн процесот.

\subsection{1 Какви проблеми кај заедниците препознаа студентите}

Таб. 2 Проблеми кои ги препознаа студентите кај заедниците

\begin{tabular}{l|l} 
Проект & Проблеми кои ги препознаа студентите \\
\hline Концепти за околината на & - лоша инфраструктура \\
Маврово & - лошо менаџрање и одржување на паркот \\
- слаба комуникација помеѓу управата на паркот, жителите и & сопствениците на приватните скијачки центри \\
& - недостиг на синергија на паркот \\
& - тешки проблеми со собирање и транспорт на отпадот \\
& - слаба култура на посетителите во однос на заштита на околината
\end{tabular}




\begin{tabular}{|c|c|}
\hline $\begin{array}{l}\text { Урбан центар за } \\
\text { креативност и одржливост }\end{array}$ & $\begin{array}{l}\text { - градот е преполн со отпадоци } \\
\text { - неинформираност на граѓаните за предностит на био-компостирањето }\end{array}$ \\
\hline $\begin{array}{l}\text { Брендирање на природна } \\
\text { македонска храна }\end{array}$ & $\begin{array}{l}\text { - неинформираност на граѓаните за предностите на органски } \\
\text { произведена храна } \\
\text { - неедуцираност на произведувачите на храна за можноста за поголема } \\
\text { заработка преку производство на органски производи } \\
\text { - недоволна „видливост“ на штандовите за органски произведена храна } \\
\text { - недоволна едуцираност за бизнис можностите за продажба на органски } \\
\text { производи }\end{array}$ \\
\hline $\begin{array}{l}\text { Нова интерпретација на } \\
\text { македонската традиција }\end{array}$ & $\begin{array}{l}\text { - жените во Дебарскиот крај имаат вештини во изработка на } \\
\text { традиционални ракотворби, но немаат финансиска корист од нив } \\
\text { - немаат можност да ги применат нивните вештини во изработка на } \\
\text { комерцијални производи } \\
\text { - немаат можност да ги применат своите вештини и знаења во } \\
\text { подобрување на нивно економско зајанување }\end{array}$ \\
\hline Проект за Протеа Мавеу & $\begin{array}{l}\text { - недоволно финансии за напредок на фармата, } \\
\text { - недоволно вода за козите и нивите, } \\
\text { - незаинтересираност на нејзината ќерка за развој на фармата поради } \\
\text { желбата за живот во градски услови. } \\
\text { - неискористеност на сите потенцијали на фармата, неорганизираност и } \\
\text { неискористеност на просторот }\end{array}$ \\
\hline $\begin{array}{l}\text { Проект за Магдалена } \\
\text { Муаса }\end{array}$ & $\begin{array}{l}\text { - лоша финансиска состојба } \\
\text { - лоши услови за одгледување на зајаци и зголемување на } \\
\text { продуктивноста }\end{array}$ \\
\hline Проект за Вилсон Ндето & $\begin{array}{l}\text { - возраста и лошата физичка кондиција на сопственикот и неговата } \\
\text { сопруга } \\
\text { - потреба од помош во одржување на фармата } \\
\text { - плодовите пропаѓаат во голем број поради недостиг на работна снага - } \\
\text { неопходна е помош за собирање и пласман на плодовите } \\
\end{array}$ \\
\hline Проект за Рафаел Мбуви & $\begin{array}{l}\text { - Капацитетот и огромните ресурси на фармата не се целосно } \\
\text { искористени } \\
\text { - преголеми трошоци за производство, најмногу за пестициди и ѓубрива } \\
\text { - површински отпад, } \\
\text { - ерозија на почвата, } \\
\text { - термити, } \\
\text { - трошоци за наводнување на земјиштето итн. }\end{array}$ \\
\hline Проект за Кевин Ваита & $\begin{array}{l}\text { - амбициите на сопственикот се многу поголеми од постигнувањата, има } \\
\text { желба да биде обучувач за одгледување на живина, } \\
\text { - егзистенцијални и финансиски проблеми кои не му дозволуваат да се } \\
\text { посвети на рализацијата на оваа амбиција. }\end{array}$ \\
\hline Проект за Џозеф Мбити & $\begin{array}{l}\text { - преголеми амбиции за иднината на фармата } \\
\text { - недостиг на стратегија за постепено реализирање на амбициозниот } \\
\text { план да ја претвори фармата во агротуристички центар } \\
\text { - фарамата има голем потенцијал но сепак не обезбедува постојан и } \\
\text { висок приход } \\
\text { - слаба инфраструктура за реализација на амбициозните планови } \\
\end{array}$ \\
\hline Проект за Ребека Муинди & $\begin{array}{l}\text { - возраст и послаба физичка кондиција на сопственичката } \\
\text { - потреба од помош во одржување на фармата } \\
\text { - ерозија на почвата, } \\
\text { - недостаток на вода, енергија и други непогоди. }\end{array}$ \\
\hline $\begin{array}{l}\text { Проект за Ресурсниот } \\
\text { центар Мачакос }\end{array}$ & $\begin{array}{l}\text { - недоволна примена на знаењето кое центарот им го пренесува на } \\
\text { земјоделците, } \\
\text { - потешкотии при продавање на органски производи по повисоки цени, } \\
\text { - стареење на земјоделците (нивната просечна возраст е } 51 \text { година) } \\
\text { - недоволна информираност на младината за производство на органски } \\
\text { производи. }\end{array}$ \\
\hline
\end{tabular}




\subsection{2 Каков вид решенија понудија студентите}

\section{Таб. 3 Понудени решенија од студентите}

\begin{tabular}{|c|c|}
\hline Проект & Решенија кои ги понудија студентите \\
\hline $\begin{array}{l}\text { Концепти за околината на } \\
\text { Маврово }\end{array}$ & $\begin{array}{l}\text { - Брендирање - лого на Националниот парк Маврово } \\
\text { - Мапа на паркот со икони за означување } \\
\text { - Патокази, инфраструктурни знаци } \\
\text { - Информативна брошура } \\
\text { - Кампања за отпад и почиста околина, правилно собирање на отпадот со } \\
\text { икони за едукација на однесувањето на посетителите } \\
\text { - Веб страна } \\
\text { - Дизајн на настрешница со клупи за одмор на посетителите } \\
\text { - Дизајн на корпи за отпадоци }\end{array}$ \\
\hline $\begin{array}{l}\text { Урбан центар за } \\
\text { креативност и одржливост }\end{array}$ & $\begin{array}{l}\text { - Формирање асоцијација на жители од одредена локација на градот кои } \\
\text { користат под наем кутии за компостирање заради преработка на } \\
\text { домашниот органски отпад во употреблива органски збогатена земја за } \\
\text { цвеќња, со можност за комерцијална примена, } \\
\text { - Уредување на атрактивен простор во кој ќе се одржуваат разни } \\
\text { културни манифестации, а еден дел од просторот ке биде користен за } \\
\text { чување на кутии за компостирање, } \\
\text { - Дизајн на лого на асоцијацијата, } \\
\text { - Информативни материјали за популаризација на процесот } \\
\text { компостирање меѓу локалното население, } \\
\text { - Дизајн на кутија за компостирање. }\end{array}$ \\
\hline $\begin{array}{l}\text { Брендирање на природна } \\
\text { македонска храна }\end{array}$ & $\begin{array}{l}\text { - концепт линија на производи добиени од билките кои растат во } \\
\text { македонските планини како прототипен пример за природно } \\
\text { одгледување, фер-трговија, македонски природни ресурси и економски } \\
\text { бенефит. } \\
\text { - дизајн на опаковка, } \\
\text { - брендирање (лого). }\end{array}$ \\
\hline $\begin{array}{l}\text { Нова интерпретација на } \\
\text { македонската традиција }\end{array}$ & $\begin{array}{l}\text { - концепт на работилница (клуб) со простор за состаноци чија цел е да се } \\
\text { мотивираат луѓето да ја изразат сопствената креативност и интерес за } \\
\text { ре-интерпретација на традиционални текстилни производи, } \\
\text { - два вида направи-сам производи: комплет со рамка за ткаење и кутија } \\
\text { со печати за печатење на традиционални облици на разни текстилни } \\
\text { производи. }\end{array}$ \\
\hline Проект за Протеа Мавеу & $\begin{array}{l}\text { - нова просторна организација на фармата како би се одвивале } \\
\text { поефикасно активностите; } \\
\text { - одводен систем со олуци и цевки, поставени на куќата и шталата за } \\
\text { животните, кои би имале функција за собирање на дождовница во } \\
\text { базен изграден примитивно и евтино во расположивиот простор до } \\
\text { куќата; } \\
\text { - нова инфраструктура (штала) за кози, како и ограда за заштита од } \\
\text { предатори; } \\
\text { - предлог план за развој на фармата со постепено финансиско } \\
\text { зајакнувања преку зголемување на бројот на кози и нивна продажба. }\end{array}$ \\
\hline $\begin{array}{l}\text { Проект за Магдалена } \\
\text { Муаса }\end{array}$ & $\begin{array}{l}\text { - предлог концепт дизајн на кафез за зајаци; } \\
\text { - упатство за изработка на кафезот; } \\
\text { - предлог план за ширење на активностите на младинската група, чиј } \\
\text { член е Магдалена, во развој на заедницата преку заедничка изградба на } \\
\text { кафези за зајаци во домаќинствата на членовите на групата. }\end{array}$ \\
\hline Проект за Вилсон Ндето & $\begin{array}{l}\text { Студентите креираа концепт за т.н. земјоделски клуб од редовите на } \\
\text { учениците од локалното училиште кој има две примарни цели со кои би }\end{array}$ \\
\hline
\end{tabular}




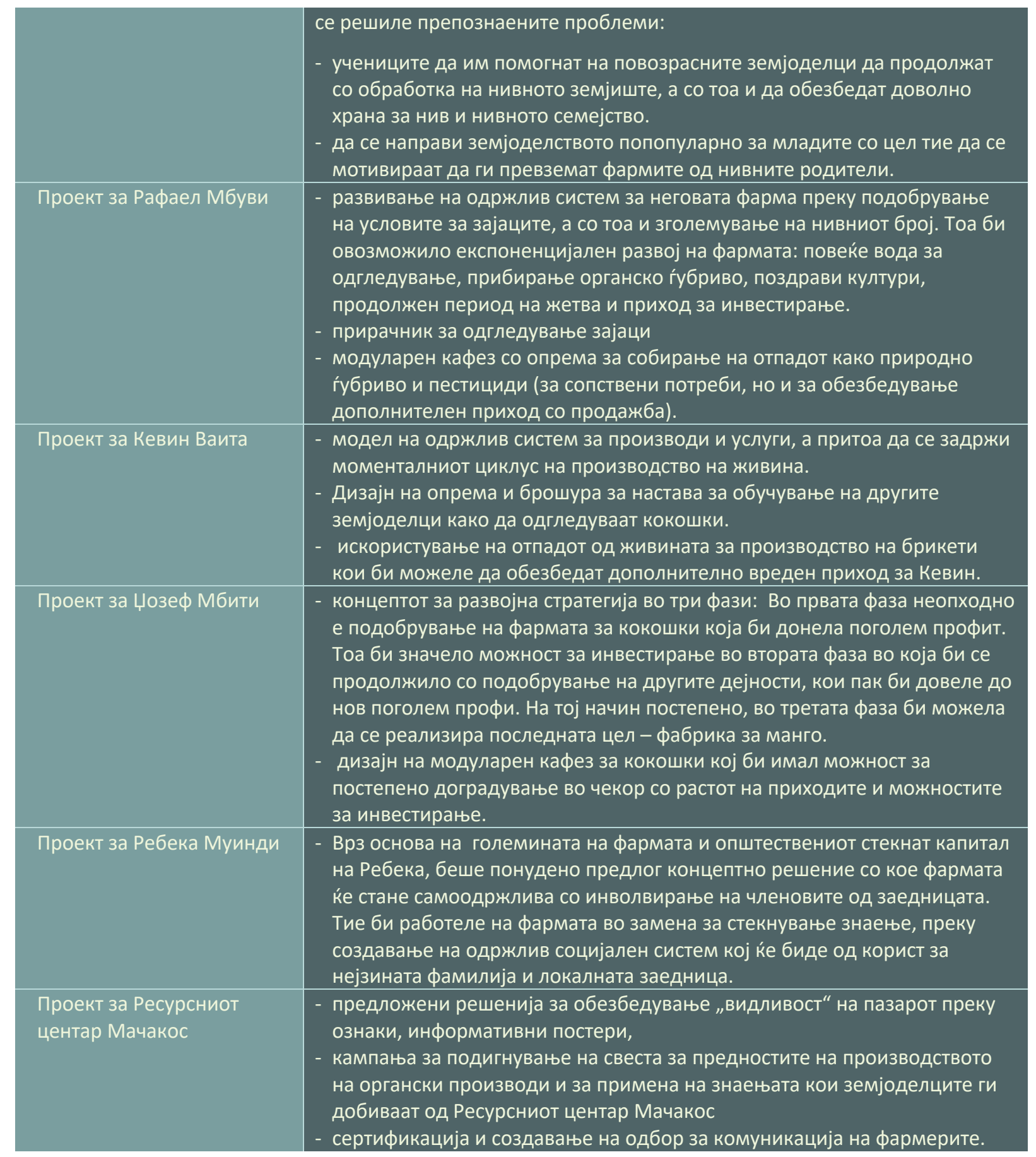

\subsection{3 Колку тие решенија беа одговор на однапред поставените очекувања}

Таб. 4 Колку понудените решенија од студентите одговорија на однапред поставените очекувања

\begin{tabular}{l|l|l} 
Проект & $\begin{array}{l}\text { Однапред поставени } \\
\text { очекувања }\end{array}$ & Решенија кои ги понудија студентите \\
\hline Концепти за & - Да се најдат решенија за & - Брендирање - лого на Националниот парк Маврово \\
околината на & проблемите на собирање и & - Мапа на паркот со икони за означување \\
Маврово & транспорт на отпадоците, & - Патокази, инфраструктурни знаци \\
& отстранување на диви & - Информативна брошура \\
& депонии. & - Кампања за отпад и почиста околина, правилно \\
& собирање на отпадот со икони за едукација на
\end{tabular}




\begin{tabular}{|c|c|c|}
\hline & & $\begin{array}{l}\text { однесувањето на посетителите } \\
\text { - Веб страна } \\
\text { - Дизајн на настрешница со клупи за одмор на } \\
\text { посетителите } \\
\text { - Дизајн на корпи за отпадоци }\end{array}$ \\
\hline $\begin{array}{l}\text { Урбан центар за } \\
\text { креативност и } \\
\text { одржливост }\end{array}$ & $\begin{array}{l}\text { - Фирмите имаат потреба од } \\
\text { подобри услови за } \\
\text { манипулација со црвите и } \\
\text { преработениот органски } \\
\text { отпад. } \\
\text { - автоматизирање на целиот } \\
\text { или дел од процесот со } \\
\text { дизајн на соодветни } \\
\text { средства за работа со кои ќе } \\
\text { се намали напорот на } \\
\text { вработените, а ќе се зголеми } \\
\text { продуктивноста. }\end{array}$ & $\begin{array}{l}\text { - Формирање асоцијација на жители од одредена } \\
\text { локација на градот кои ќе користат под наем кутии за } \\
\text { компостирање заради преработка на домашниот } \\
\text { органски отпад во употреблива органски збогатена } \\
\text { земја за цвеќњња, со можност за комерцијална } \\
\text { примена, } \\
\text { - Уредување на атрактивен простор во кој ќе се } \\
\text { одржуваат разни културни манифестации, а еден дел } \\
\text { од просторот ќе биде користен за чување на кутии за } \\
\text { компостирање, } \\
\text { - Дизајн на лого на асоцијацијата, } \\
\text { - Информативни материјали за популаризација на } \\
\text { процесот компостирање меѓу локалното население, } \\
\text { - Дизајн на кутија за компостирање. }\end{array}$ \\
\hline $\begin{array}{l}\text { Брендирање на } \\
\text { природна } \\
\text { македонска } \\
\text { храна }\end{array}$ & $\begin{array}{l}\text { - креативни решенија за } \\
\text { пакување и логистика за } \\
\text { органски производи } \\
\text { - да се промовира и } \\
\text { популаризира овој вид } \\
\text { производи } \\
\end{array}$ & $\begin{array}{l}\text { - концепт линија на производи добиени од билките кои } \\
\text { растат во македонските планини како прототипен } \\
\text { пример за природно одгледување, фер-трговија, } \\
\text { македонски природни ресурси и економски бенефит. } \\
\text { - дизајн на опаковка, } \\
\text { - брендирање (лого). }\end{array}$ \\
\hline $\begin{array}{l}\text { Нова } \\
\text { интерпретација } \\
\text { на } \\
\text { македонската } \\
\text { традиција }\end{array}$ & $\begin{array}{l}\text { - економско зајакнување на } \\
\text { жените од Дебарско преку } \\
\text { искористување на нивните } \\
\text { знаења и вештини во } \\
\text { изработка на ракотворби за } \\
\text { продажба } \\
\text { - заедничка работа и } \\
\text { кокреирање на вештите } \\
\text { изработувачки на } \\
\text { ракотворби и дизајнерите } \\
\end{array}$ & $\begin{array}{l}\text { - концепт на работилница (клуб) со простор за } \\
\text { состаноци чија цел е да се мотивираат луѓето да ја } \\
\text { изразат сопствената креативност и интерес за ре- } \\
\text { интерпретација на традиционални текстилни } \\
\text { производи, } \\
\text { - два вида направи-сам производи: комплет со рамка за } \\
\text { ткаење и кутија со печати за печатење на } \\
\text { традиционални облици на разни текстилни } \\
\text { производи. }\end{array}$ \\
\hline $\begin{array}{l}\text { Проект за } \\
\text { Протеа Мавеу }\end{array}$ & $\begin{array}{l}\text { - Немаше однапред поставени } \\
\text { очекувања }\end{array}$ & $\begin{array}{l}\text { - нова просторна организација на фармата како би се } \\
\text { одвивале поефикасно активностите; } \\
\text { - одводен систем со олуци и цевки, поставени на куќата } \\
\text { и шталата за животните, кои би имале функција за } \\
\text { собирање на дождовница во базен изграден } \\
\text { примитивно и евтино во расположивиот простор до } \\
\text { куќата; } \\
\text { - нова инфраструктура (штала) за кози, како и ограда за } \\
\text { заштита од предатори; } \\
\text { - предлог план за развој на фармата со постепено } \\
\text { финансиско зајакнувања преку зголемување на бројот } \\
\text { на кози и нивна продажба. }\end{array}$ \\
\hline $\begin{array}{l}\text { Проект за } \\
\text { Магдалена } \\
\text { Муаса }\end{array}$ & $\begin{array}{l}\text { - Немаше однапред поставени } \\
\text { очекувања }\end{array}$ & $\begin{array}{l}\text { - предлог концепт дизајн на кафез за зајаци; } \\
\text { - упатство за изработка на кафезот; } \\
\text { - предлог план за ширење на активностите на } \\
\text { младинската група, чиј член е Магдалена, во развој на } \\
\text { заедницата преку заедничка изградба на кафези за } \\
\text { зајаци во домаќинствата на членовите на групата. }\end{array}$ \\
\hline $\begin{array}{l}\text { Проект за } \\
\text { Вилсон Ндето }\end{array}$ & $\begin{array}{l}\text { - Немаше однапред поставени } \\
\text { очекувања }\end{array}$ & $\begin{array}{l}\text { Студентите креираа концепт за т.н. земјоделски клуб од } \\
\text { редовите на учениците од локалното училиште кој има } \\
\text { две примарни цели со кои би се решиле препознаените } \\
\text { проблеми: } \\
\text { - учениците да им помогнат на повозрасните } \\
\text { земјоделци да продолжат со обработка на нивното }\end{array}$ \\
\hline
\end{tabular}




\begin{tabular}{|c|c|c|}
\hline & & $\begin{array}{l}\text { земјиште, а со тоа и да обезбедат доволно храна за } \\
\text { нив и нивното семејство. } \\
\text { - да се направи земјоделството попопуларно за } \\
\text { младите со цел тие да се мотивираат да ги превземат } \\
\text { фармите од нивните родители. }\end{array}$ \\
\hline $\begin{array}{l}\text { Проект за } \\
\text { Рафаел Мбуви }\end{array}$ & $\begin{array}{l}\text { - Немаше однапред поставени } \\
\text { очекувања }\end{array}$ & $\begin{array}{l}\text { - развивање на одржлив систем за неговата фарма } \\
\text { преку подобрување на условите за зајаците, а со тоа и } \\
\text { зголемување на нивниот број. Тоа би овозможило } \\
\text { експоненцијален развој на фармата: повеќе вода за } \\
\text { одгледување, прибирање органско ѓббиво, поздрави } \\
\text { култури, продолжен период на жетва и приход за } \\
\text { инвестирање. } \\
\text { - прирачник за одгледување зајаци } \\
\text { - модуларен кафез со опрема за собирање на отпадот } \\
\text { како природно ѓубриво и пестициди (за сопствени } \\
\text { потреби, но и за обезбедување дополнителен приход } \\
\text { со продажба). }\end{array}$ \\
\hline $\begin{array}{l}\text { Проект за Кевин } \\
\text { Ваита }\end{array}$ & $\begin{array}{l}\text { - Немаше однапред поставени } \\
\text { очекувања }\end{array}$ & $\begin{array}{l}\text { - модел на одржлив систем за производи и услуги, а } \\
\text { притоа да се задржи моменталниот циклус на } \\
\text { производство на живина. } \\
\text { - Дизајн на опрема и брошура за настава за обучување } \\
\text { на другите земјоделци како да одгледуваат кокошки. } \\
\text { - искористување на отпадот од живината за } \\
\text { производство на брикети кои би можеле да обезбедат } \\
\text { дополнително вреден приход за Кевин. }\end{array}$ \\
\hline $\begin{array}{l}\text { Проект за } \\
\text { Џозеф Мбити }\end{array}$ & $\begin{array}{l}\text { - Немаше однапред поставени } \\
\text { очекувања }\end{array}$ & $\begin{array}{l}\text { - концептот за развојна стратегија во три фази: Во } \\
\text { првата фаза неопходно е подобрување на фармата за } \\
\text { кокошки која би донела поголем профит. Тоа би } \\
\text { значело можност за инвестирање во втората фаза во } \\
\text { која би се продолжило со подобрување на другите } \\
\text { дејности, кои пак би довеле до нов поголем профи. На } \\
\text { тој начин постепено, во третата фаза би можела да се } \\
\text { реализира последната цел - фабрика за манго. } \\
\text { - дизајн на модуларен кафез за кокошки кој би имал } \\
\text { можност за постепено доградување во чекор со растот } \\
\text { на приходите и можностите за инвестирање. }\end{array}$ \\
\hline $\begin{array}{l}\text { Проект за } \\
\text { Ребека Муинди }\end{array}$ & $\begin{array}{l}\text { - Немаше однапред поставени } \\
\text { очекувања }\end{array}$ & $\begin{array}{l}\text { - Врз основа на големината на фармата и } \\
\text { општествениот стекнат капитал на Ребека, беше } \\
\text { понудено предлог концептно решение со кое фармата } \\
\text { ќ стане самоодржлива со инволвирање на членовите } \\
\text { од заедницата. Тие би работеле на фармата во замена } \\
\text { за стекнување знаење, преку создавање на одржлив } \\
\text { социјален систем кој ке биде од корист за нејзината } \\
\text { фамилија и локалната заедница. }\end{array}$ \\
\hline $\begin{array}{l}\text { Проект за } \\
\text { Ресурсниот } \\
\text { центар Мачакос }\end{array}$ & $\begin{array}{l}\text { - Немаше однапред поставени } \\
\text { очекувања }\end{array}$ & $\begin{array}{l}\text { - предложени решенија за обезбедување „видливост“ } \\
\text { на пазарот преку ознаки, информативни постери, } \\
\text { - кампања за подигнување на свеста за предностите на } \\
\text { производството на органски производи и за примена } \\
\text { на знаењата кои земјоделците ги добиваат од } \\
\text { Ресурсниот центар Мачакос } \\
\text { - сертификација и создавање на одбор за комуникација } \\
\text { на фармерите. }\end{array}$ \\
\hline
\end{tabular}




\section{4 Извлечени заклучоци}

Од прегледот даден во табелите може да се забележи дека за потребите на работилницата во Скопје НВО Свисконтакт препозна неколку заедници со конкретни проблеми. Во описите беа дадени и очекувањата од проектите кои треба да се реализираат. Се забележува дека овие очекувања во првите три проекти само делумно беа исполнети, а во четвртиот воопшто не беа исполнети. Но, она што беше забележано е дека студентите со успешно спроведени истражувања и примена на дизајн техники и методи успеаја да препознаат проблеми за кои членовите на заедниците не беа воопшто свесни. Врз основа на добро дефинираните проблеми тие понудија квалитетни дизајнерски решенија од различен облик.

Истражувачкиот тим кој работеше на анализа на резултатите од работилниците ја согледа моќта на набљудувањето и препознавањето на проблемите, кои членовите на заедниците во нивното секојдневие често пати не можат да ги забележат. Поради тоа, донесена одлука да не се дефинираат дизајн проблеми за работилницата во Кенија, туку да се остават членовите на тимовите сами да ги препознаат, анализираат и дефинираат. Оваа одлука се покажа како многу исправна, што продуцира голем број правилно дефинирани и решени дизајн проблеми.

Во сите проекти беше јасно забележано дека почетокот на дизајн процесот е речиси хаотичен и нејасен. Во овој дел се вршеше испитување на можните аспекти, анализирање на можни правци кон кои треба да се движи дизајн процесот, инспирирање, истражувањето на отворени прашања. Најчесто не беше познато дали резултатот од процесот на дизајнирање ќе биде услуга, производ, брендирање, систем на информирање, форми на здружување итн. Размислувањата во овој дел беше поврзан со истражувањето и изборот на технолошки можности, избор на расположиви или достапни материјали, технологии, разбирање на корисниците во контекстите на користење итн. Всушност целта на истражувањето од овој дел е да се одреди што е потребно да се дизајнира, а понекогаш и тоа што не треба да се дизајнира и произведе. Дури по донесувањето на одлуките што треба да се дизајнира процесот продолжуваше по вообичаениот тек. 


\section{5. Истражување на резултатите од работилниците со примена на видео етнографија и втемелена теорија}

Истражувачкиот дел на проектот „Дизајн со општествено влијание“ се состоеше од детално проучување на сите материјали собрани во текот на реализацијата на сите реализирани работилници, во текот на кои беа документирани сите чекори од дизајн процесот. При тоа беа употребени етнографски истражувачки методи кои придонесоа истражувањето да добие темелна основа.

Од активностите во рамките на работилниците беше креирана огромна архива на податоци во различни формати: текстови, видео снимки, аудио снимки, фотографии, скици, дијаграми и белешки. Најзначајни податоци се генерираа од спроведената видео етнографија, особено од интервјуа и т.н. „мува на sид“ набљудувања (Сл. 87). Мојата улога во овој проект беше набљудување и видео документирање на процесот на работа во текот на работилниците, но и во нивно средување и анализирање со примена на т.н. втемелена теорија.

Процесот на истражување се одвиваше во четири фази: запознавање, креирање смисла, имплементирање во наставната програма и тестирање на резултатите и знаењата. Истражувањето започна веднаш по реализацијата на работилниците во Цирих и Скопје, при што беа извлечени вредни заклучоци во вид на знаења за дизајн процесот. Тие подоцна беа применети во едукативниот процес при реализација на работилницата во Кенија, а потоа беше извршена евалуација на ефектите од нивната примена.

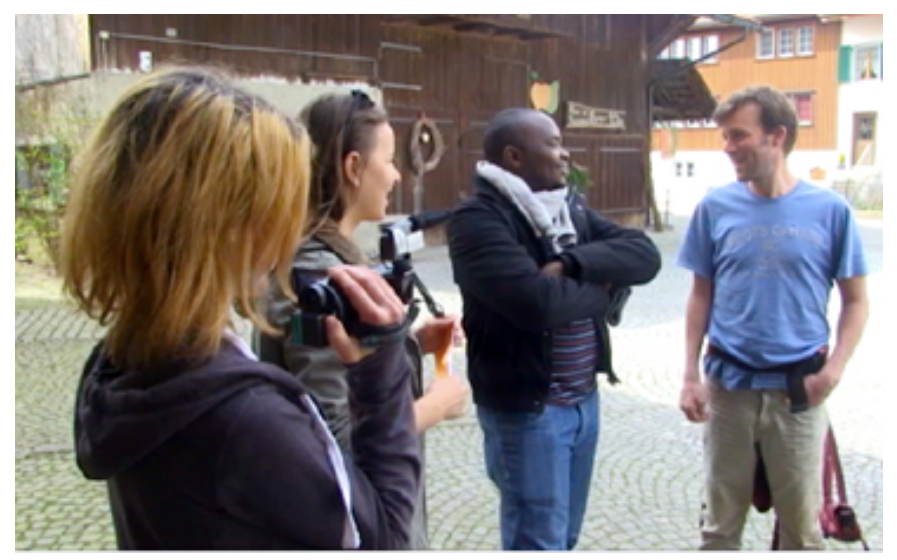

Сл. 87 Сцени од видео етнографско истражување 
Истражувачкиот тим на проектот „Дизајн со општествено влијание“ имаше прецизно осмислена стратегија за спроведување на етнографското истражување во неколку фази. Беа точно прецизирани аспектите, полињата на интерес, како теми на истражувањето, но и таргет групите за испитување [26].

\section{1 Собирање етнографски материјали на работилниците во Цирих и Скопје}

Првата фаза од етнографското истражување беше реализирана преку собирање материјали во текот на активностите на работилниците во Цирих и Скопје.

Иако беа дефинирани појдовните полиња на интерес за набљудување, сепак постоеше можност за додавање на други интересни аспекти. Беа набљудувани сите активности на актерите и дополнително се правеа интервјуа со нив. Прашањата за интервјуата беа претходно подготвени како упатство и инспирација за набљудувањето, а по потреба се дополнуваа и променуваа. Интервјуата се одржуваа со сите групи на актери во сите фази на дизајн процесот.

Од суштинско значење беше набљудувањето и истражувањето добро да се документираат. Се земаа белешки, се собираа цитати, се пишуваа рефлексии, секогаш внимателно се зачувуваа аудио и видео снимките, а притоа постојано се подредуваше целокупниот материјал во стандардизирана структура од датотеки.

Полиња на интерес:

- соработката како социјална интеракција помеѓу дизајн тимот и заедницата,

- културните разлики на сите нивоа,

- процесот на учење на студентите во тимовите.

Таргет групи (актери) на истражувањето:

- студенти,

- наставници,

- заедница на корисници и

- невладини организации.

Фази од процесот во кои се вршеа етнографските истражувања

- истражување на терен и анализи,

- генерирање идеи, хипотези,

- синтеза и прототипирање,

- итерација, имплементација, документација. 


\section{2 Евалуација и интерпретација на собраниот материјал од етнографскотот}

истражување на работилниците во Цирих и Скопје

По завршувањето на двете работилници, собраниот материјал детално се разгледа, селектира, анализира, евалуира и интерпретира од страна на членовите од истражувачкиот тим. За таа цел беше изготвена Ексел табела во која истражувачите ги внесуваа интерпретациите од истражениот материјал. Се интерпретираа видео примероци од дизајн процес со заедницата, дизајн процес без заедницата, интервјуа со членови на заедницата, интервјуа со членови на невладината организација, интервјуа со студенти и интервјуа со наставници.

Интерпретациите од видео примероците се групираа во претходно одредени кластери од фокусот на истражувањето на овој проект, а произлегоа и нови кластери од самите интерпретации. Откако се изготви Ексел табела со многубројни интерпретации (сл. 89), следеше креирање на Ексел табела со селектирани најдобри интерпретации (сл. 88) и Ексел табела со интерпретации од интервјуа (сл. 90).

Етнографското истражување резултираше со многубројни интерпретации и дефинирање на следните кластери:

- интеркултурно искуство,

- образоование,

- дизајн процес,

- соработка со заедницата,

- соработка со невладина организација,

- цели,

- организација.

Дефинираните интерпретации и кластери претставува основа за почеток на истражувањето по метод на втемелена теорија. 


\begin{tabular}{|c|c|c|c|c|c|}
\hline 30.05.2016 - selected - park & 00:02:08 - 00:02:33 & $\begin{array}{l}\text { 30.05.2016 - selected - } \\
\text { park_crop_01 }\end{array}$ & Making decisions through voting & $\begin{array}{l}\text { The team made their decisions which } \\
\text { goals that they previously written should } \\
\text { they follow up in the next phases in the } \\
\text { project The decisions were made through } \\
\text { voting. Each member chose goals in } \\
\text { which i interested in and thinks they are } \\
\text { important }\end{array}$ & C: Design Process \\
\hline all videos 01.06 & $00: 25: 06-00: 25: 47$ & all videos 01.06 _crop_01 & $\begin{array}{l}\text { Question to the students from this team } \\
\text { about which chalenges did they faced } \\
\text { during idea generation and how did they } \\
\text { deal with h hese challenges, and also } \\
\text { about their opinion for their division in to } \\
\text { smaller teams }\end{array}$ & $\begin{array}{l}\text { They think that its important to focus on } \\
\text { something because they are more } \\
\text { members and were discussing a lot of } \\
\text { time and also they had so many things to } \\
\text { do. Regarding to the division in smaller } \\
\text { groups they think that for one day it was } \\
\text { good that they separated but at that } \\
\text { moment they needed to join together in } \\
\text { order to accomplish their future goals that } \\
\text { must be done in teamwork }\end{array}$ & C: Design Process \\
\hline selected_27_05 & 00:08:14 - 00:08:56 & selected_27_05_crop_03 & $\begin{array}{l}\text { Asking for opinion from the Faculty of } \\
\text { Agricultural Sciences and Food about the } \\
\text { idea of home urban gardening }\end{array}$ & $\begin{array}{l}\text { Their opinion is that this idea might be of } \\
\text { interest for people living in more spacious } \\
\text { homes, for example houses }\end{array}$ & D: Community Collaboration \\
\hline park - 25.05.2016 - selected & $00: 24: 25-00: 24: 51$ & $\begin{array}{l}\text { park - 25.05.2016- } \\
\text { selected_crop_07 }\end{array}$ & $\begin{array}{l}\text { Question to the Swiss students from this } \\
\text { team about thow they experienced the } \\
\text { reactions of the community to their ideas }\end{array}$ & $\begin{array}{l}\text { They had discovered that the people are } \\
\text { getting afraid when they are apporoached } \\
\text { by a bigger group of students and are } \\
\text { getting less communicative, but when they } \\
\text { had approached them with a smaller } \\
\text { groups of students the people were more } \\
\text { open for colllaboration. Also they found } \\
\text { that young poople are more collaborative }\end{array}$ & D: Community Collaboration \\
\hline
\end{tabular}

\section{Сл. 88 Избрани интерпретации}

\begin{tabular}{|c|c|c|c|c|c|}
\hline \multicolumn{5}{|c|}{ DWSI Project 2 Skopje - Macedonia \& Switzerland "Learning from each other" } & 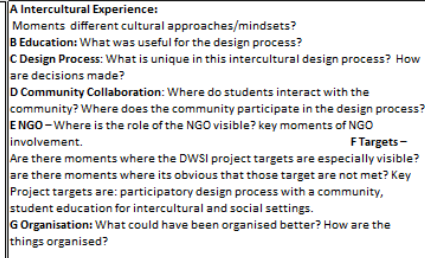 \\
\hline Originalfile_Name & Timecode (hh:mm:ss) & New_Filename & Description & Interpretation & Clusters \\
\hline bio-worm_24_05_crop & 00:00:42 - 00::01:01 & bio-worm_24_05_crop_01 & $\begin{array}{l}\text { BIOFLOR employee explaining the } \\
\text { industry }\end{array}$ & $\begin{array}{l}\text { Community contribution on the analysis } \\
\text { phase of the design process. The } \\
\text { companies were found by the NGO }\end{array}$ & E:NGO \\
\hline bio-worm_24_05_crop & |00:05:25 - 00:06:22 & bio-worm_24_05_crop_02 & $\begin{array}{l}\text { Discussion about farmers business } \\
\text { mindsets in Macedonia }\end{array}$ & $\begin{array}{l}\text { Difference in business mindsets of } \\
\text { Macedoniun/Balken farmers compared to } \\
\text { other countriesrregions }\end{array}$ & A: Intercultural Experience \\
\hline bio-worm_24_05_crop & 00:06:37 - 00:07:27 & bio-worm_24_05_crop_03 & $\begin{array}{l}\begin{array}{l}\text { Discussion about avareness and } \\
\text { acceptanceco of organic products in } \\
\text { Mecedonia }\end{array} \\
\end{array}$ & $\begin{array}{l}\text { Knowing the actual situation of this } \\
\text { industry in Macedonia will be of great } \\
\text { use for determinining the focus of work in } \\
\text { the next phases of the design process }\end{array}$ & B: Education \\
\hline Win whom on os ne aman & 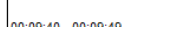 & 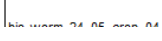 & |BIOFLOR employee promise that they & 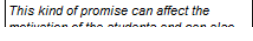 & \\
\hline
\end{tabular}

Сл. 89 Сите интерпретации

\begin{tabular}{|c|c|c|c|c|c|}
\hline 31_05_crop & 00:05:58 - 00:06:29 & 31_05_crop_crop_03 & $\begin{array}{l}\text { Question to the Macedonian students from } \\
\text { this team about how they experienced the } \\
\text { reactions of the community to their ideas }\end{array}$ & $\begin{array}{l}\text { The reactions were very positive, but until } \\
\text { now only a small amount of the } \\
\text { community has been approached }\end{array}$ & D: Community Collaboration \\
\hline selected_27_05 & 00:08:14- 00:08:56 & selected_27_05_crop_03 & $\begin{array}{l}\text { Asking for opinion from the Faculty of } \\
\text { Arricultural Sciences and Food about the } \\
\text { idea of home urban gardening }\end{array}$ & \begin{tabular}{|l|} 
Their opinion is that this idea might be of \\
interest for people living in more spacious \\
homes, for example houses
\end{tabular} & D: Community Collaboration \\
\hline park - 25.05.2016 - selected & $00: 24: 25-00: 24: 51$ & $\begin{array}{l}\text { park - 25.05.2016 - } \\
\text { selected_crop_07 }\end{array}$ & $\begin{array}{l}\text { Question to the Swiss students from this } \\
\text { team about thow they exporienced the } \\
\text { reactions of the community to their ideas }\end{array}$ & $\begin{array}{l}\text { They had discovered that the people are } \\
\text { getting afraid when they are approached } \\
\text { by a bigger group of students and are } \\
\text { getting less communicative, but when they } \\
\text { had approached them with a smaller } \\
\text { groups of students the people were more } \\
\text { open for collaboration. Also they found } \\
\text { that young people are more collaborative }\end{array}$ & D: Community Collaboration \\
\hline 24.05_selected_noST & 00:16:51 - 00:17:15 & 24.05_selected_noST_crop_03 & $\begin{array}{l}\text { Planning the next steps for the field } \\
\text { research }\end{array}$ & $\begin{array}{l}\text { The team is planning to split in smaller } \\
\text { groups to gain on efficiency. Spliting in } \\
\text { smaller groups gives the team a chance to } \\
\text { make more interviews at the same time, } \\
\text { its easier for the people to give interviews } \\
\text { in front of smaller group, to make } \\
\text { interviews on more locations at the same } \\
\text { time etc. }\end{array}$ & G: Organisation \\
\hline
\end{tabular}

Сл. 90 Интерпретации од интервјуа 


\section{3 Анализа на собраниот материјал од етнографскотот истражување на работилниците во Цирих и Скопје}

Откако заврши евалуацијата и интерпретацијата на собраниот материјал од двете работилници, се одржаа две истражувачки работилници каде истражувачите работеа со примена на пристап базиран на втемелена теорија.

Резултатите од анализата со помош на втемелената теорија ги покажаа празните места во истражувањето и неопходните аспекти за подобрување на едукативните работилници. Генерираните знаења од истражувањето беа имплементирани во работниот план и планот за етнографското истражување на третата едукативна работилница во Кенија.

\section{4 Собирање етнографски материјали на работилницата во Кенија}

За разлика од претходните работилници, набљудувањето на третата работилница се одвиваше со фокус на имплементираните знаења од истражувањето. Набљудувањето започна уште при подготовката на работилницата кога студентите, професорите и истражувачите се претставуваа лично со видео и ги презентираа нивните надежи и очекувања за работилницата.

Во текот на работилниците беа набљудувани следните аспекти:

- процесот на едукацијата на студентите и нивната подготовка од страна на професорите;

- како студентите го планираат процесот на кокреација со заедниците;

- алатки, прототипи, методи на визуелизација со кои се служеа студентите за процесот на соработката,

- интервјуа со студентите за овој процес.

Од претходните работилници беше согледано дека во еден проект за дизајн со општествено влијание од клучно значење е соработката помеѓу студентите и членовите на заедницата, па поради тоа при набљудувањето се посвети поголемо внимание на овој процес. Целиот процес на соработка се набљудуваше константно при истражувањата на терен, состаноците со заедницата, разговорите, активностите, како и интеракциите. По завршувањето на процесот на кокреација беа направени интервјуа со членовите на невладината организација и студентите, а на крајот од работилницата беа направени интервјуа и со членовите на заедницата. 
Набљудувањето на активностите при оваа работилница беше фокусирано кон четирите области на учење добиени како резултат од истражувањето со пристапот втемелена теорија, кои се покажаа како клучни во текот на целиот процес:

- начин на размислување и меки вештини,

- комуникација и зборови,

- односи и улоги,

- соработка и заедница.

Како за првите две работилници, така и за третата, собраниот етнографски материјал беше разгледан, селектиран, анализиран, евалуиран и интерпретиран. Меѓутоа, за разлика од претходната евалуација која се изврши со цел генерирање нови знаења, оваа видео евалуација послужи за евалуирање на претходно генерираните знаења кои беа имплементирани во третата работилница. Поради тоа, покрај образование, беа додадени кластерите: начин на размислување и меки вештини, комуникација и зборови, односи и улоги, соработка и заедница.

\section{5 Систематизација на извлечените заклучоци и знаења од спроведеното етнографско истражување во согласност со т.н. „втемелена теорија“}

Откако се комплетира етнографското истражување се премина кон истражување со пристап на втемелена теорија. За таа цел истражувачкиот тим одржа две истражувачки работилници од кои првата беше наменета за евалуација, интерпретација, оценка, толкување и доделување, а втората за врски и корелации [26].

Етнографскиот материјал од двете работилници беше приоритизиран и сортиран BO:

- Соработка со заедницата и

- Соработка без заедницата.

Видео материјалите беа разгледани, дискутирани и анализирани од истражувачкиот тим. За да се постигне објективност при анализата истражувачкиот тим се подели во две групи кои ги евалуираа видеата од проектите во кои тие не учествуваа директно. 
Истражувањето со пристапот базиран на втемелена теорија се одвиваше во четири главни чекори (Сл. 91):

- отворено кодирање,

- категории,

- аксијално кодирање и

- извлекување хипотези.

За секој чекор беа напишани белешки и визуелно мапирани (Сл. 103).
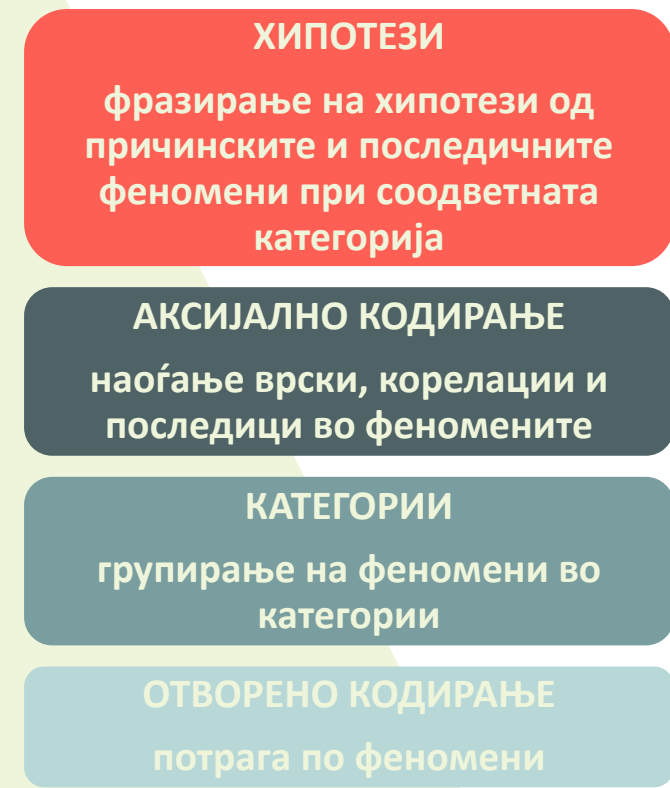

Сл. 91 Цели на главните чекори на втемелена теорија

На првата истражувачка работилница беше прегледан и оценет визуелниот материјал кој беше интерпретиран од првите две едукативни работилници, беа евалуирани и интерпретирани избрани видео фрагменти, и дефинирани кластери. Подоцна се премина кон доделување на материјалот до идентификуваните кластери и наоѓaње на мета нивоа и следни чекори на апстракција.

Во втората работилница се започна со создавање логика, односно пронаоѓање врски и корелации пропратени со идентификување на дополнителен материјал. Следеше градење на реципроцитет, а на крај се истражуваше со пристапот втемелена теорија (Сл. 92). Исходот од оваа истражувачка работилница беа извлечени хипотези и теории. 


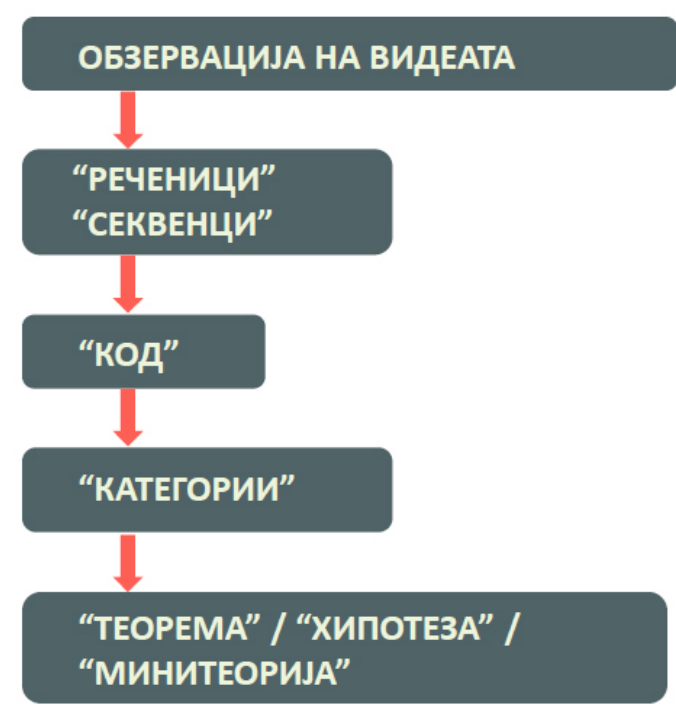

Сл. 92 Применети чекори според втемелена теорија

\section{Чекор 1. Отворено кодирање}

Првиот чекор е потрага по феномени во материјалот. Истражувачкиот тим ги прегледа видеата и избра феномени и моменти. Феномените се опишуваат во квадрати со сина боја (Сл. 93).

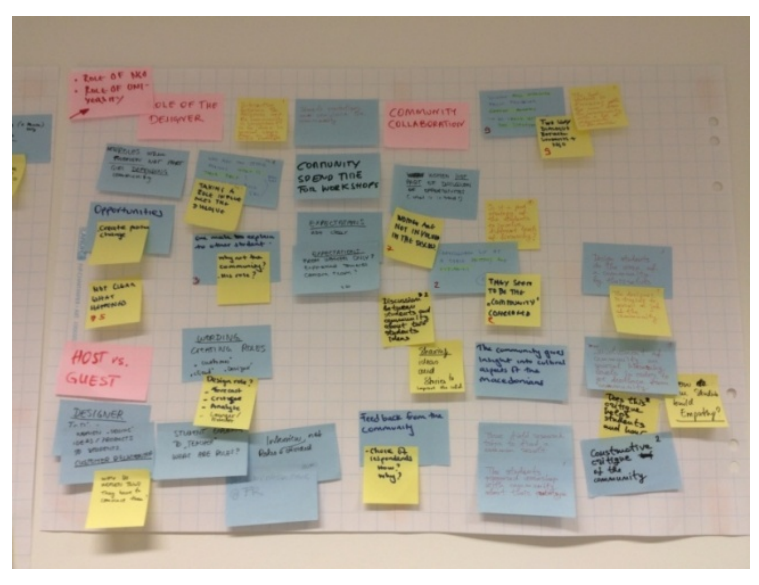

Сл. 93 Отворено кодирање

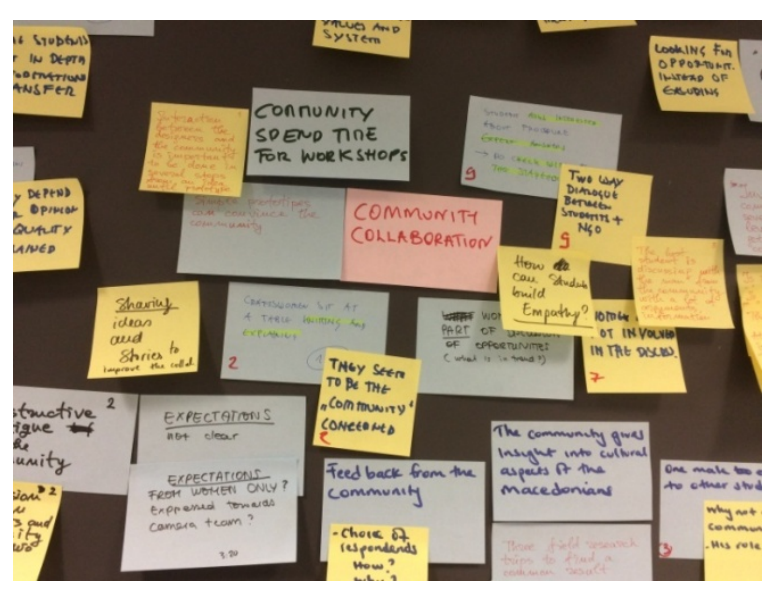

Сл. 94 Категории

\section{Чекор 2. Категории}

Во овој чекор феномените се групираат во категории (Сл. 94). Првично феномените кои се поврзани се групираат, а потоа се бара наслов на категорија за групите од феномени (во квадрати со сина боја). Категоријата се опишува во квадрат со розева боја и се позиционира во центарот на шаблонот. За секоја категорија се започнува нова страница. 
Овој чекор од истражувањето резултираше со следниве категории кои подоцна дополнително се евалуираа и дефинираа:

- Координација и подготовка

- Тимска динамика

- Работна постапка

- Невербална комуникација / вербална комуникација

- Превод

- Улогата на дизајнерот, улогата на НВО и засегнатите страни

- Хиерархија

- Културни референтни системи

- Учество

- Вклученост на заедницата

\section{Чекор 3. Аксијално кодирање}

Со аксијалното кодирање се наоѓаат врски, корелации и последици во феномените (Сл. 95). Во табелата феномените се сортираат така што причините се сместуваат на левата страна, а последиците на десната страна (Сл. 96).

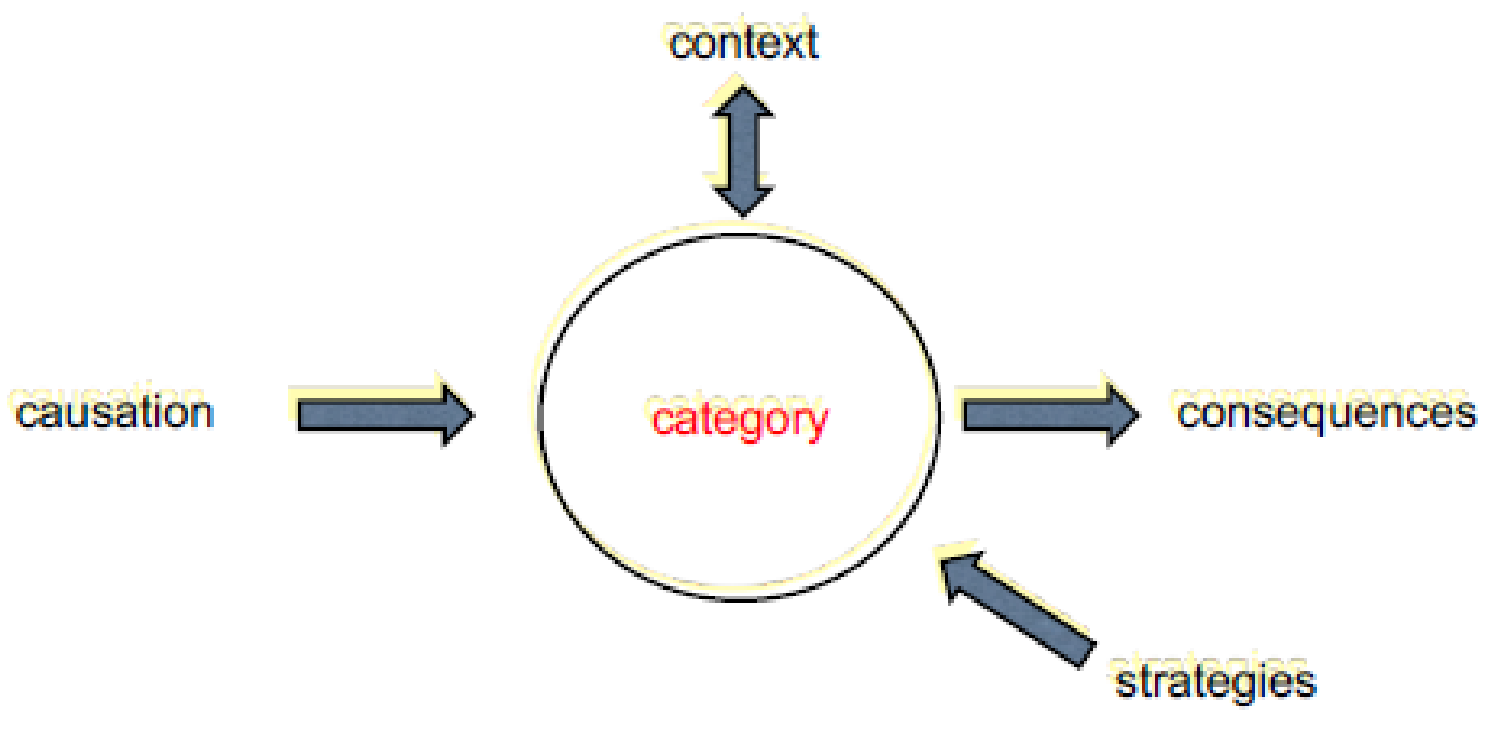

Сл. 95 Аксијално кодирање 


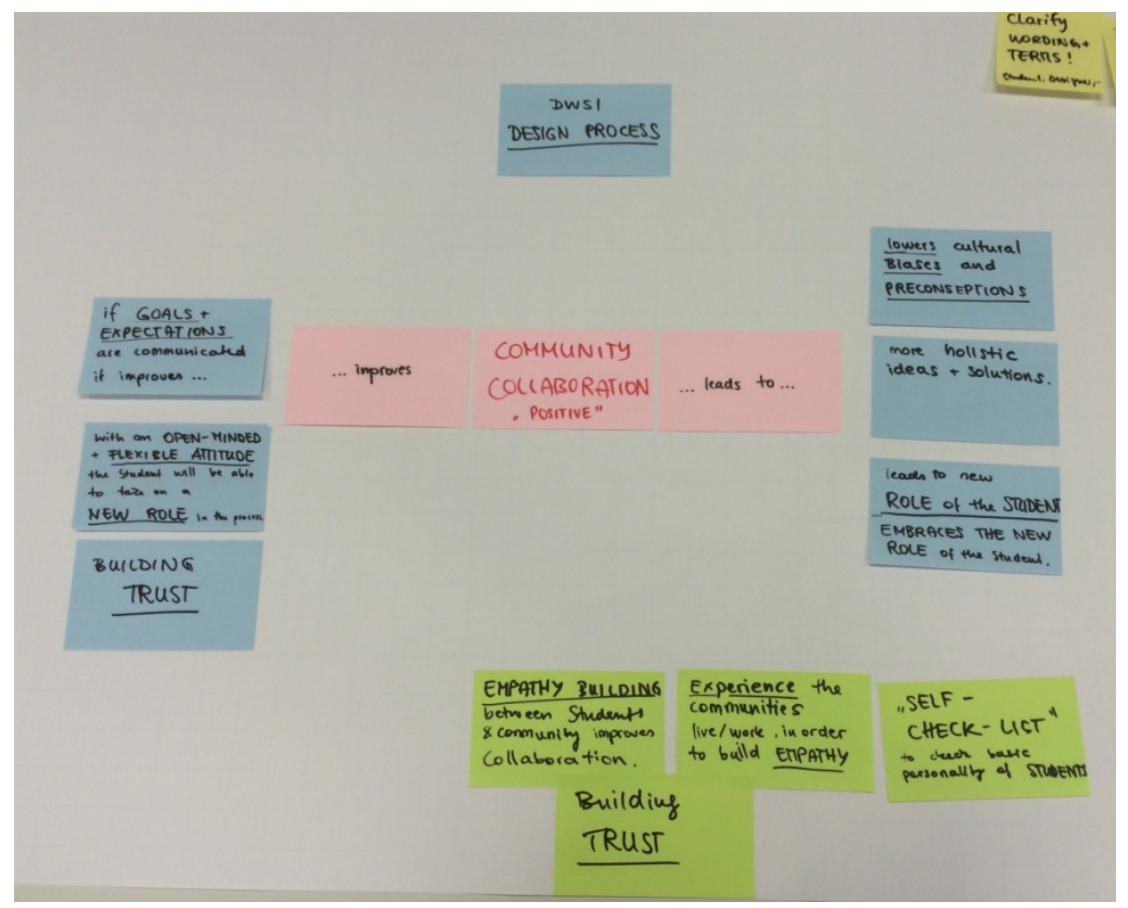

Сл. 96 Примена на аксијално кодирање

\section{Чекор 4. Хипотези}

По групирањето на феномените во категори и сортирањето на феномените по причини и последици се овозможува да се фризираат хипотезите. Тие се опишуваат во квадрат со зелена боја и се позиционираат во долната област од табелата.

Следната колекција на хипотези е резултатот од овој чекор:

- Диспозиција: зборови (Сл.97)

Зборови = Зборовите што се користат за да се изрази нешто; начинот на кој се изразува нешто (Оксфордски речник)

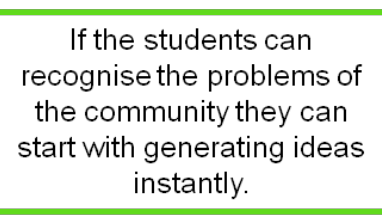

If translator is aware of translation process (no interpretation) he is less likely to influence in one direction

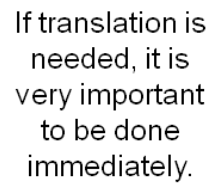

If translation is needed, it is very important to be done immediately.
The fly on the wall method can be very useful (Observation of the things from neutral position) Some of the problems are usualy not visible for the community.
The teacher has to find the right questions in order to empower the right directions in the design process.

If the wording (client, community, etc..) is choosen carfeully, the role of the designer becomes more clear and the project becomes collaborative.
Presence of instituations (NGOs) at field research harms participation on eye level

Сл.97 Хипотези во врска со зборовите

- Диспозиција: Начин на размислување (Сл. 98)

Начин на размислување = воспоставени сет на ставови што ги поседува некој (оксфордски речник) 
Овие ставови на учесниците во работилницата (ученици, наставници, истражувачи, претставници на невладини организации, членови на заедницата) покажаа дека имаат влијание врз процесот на работилница и резултатите. Начинот на размислување влијае и се поврзува со сите аспекти на работилницата, особено:

- Тимска динамика, улога на дизајнерот

- Културни предрасуди

- Градење емпатија помеѓу студентите и помеѓу студентите и заедницата

- Вклученост и учество на заедницата (Процес на ко-создавање)

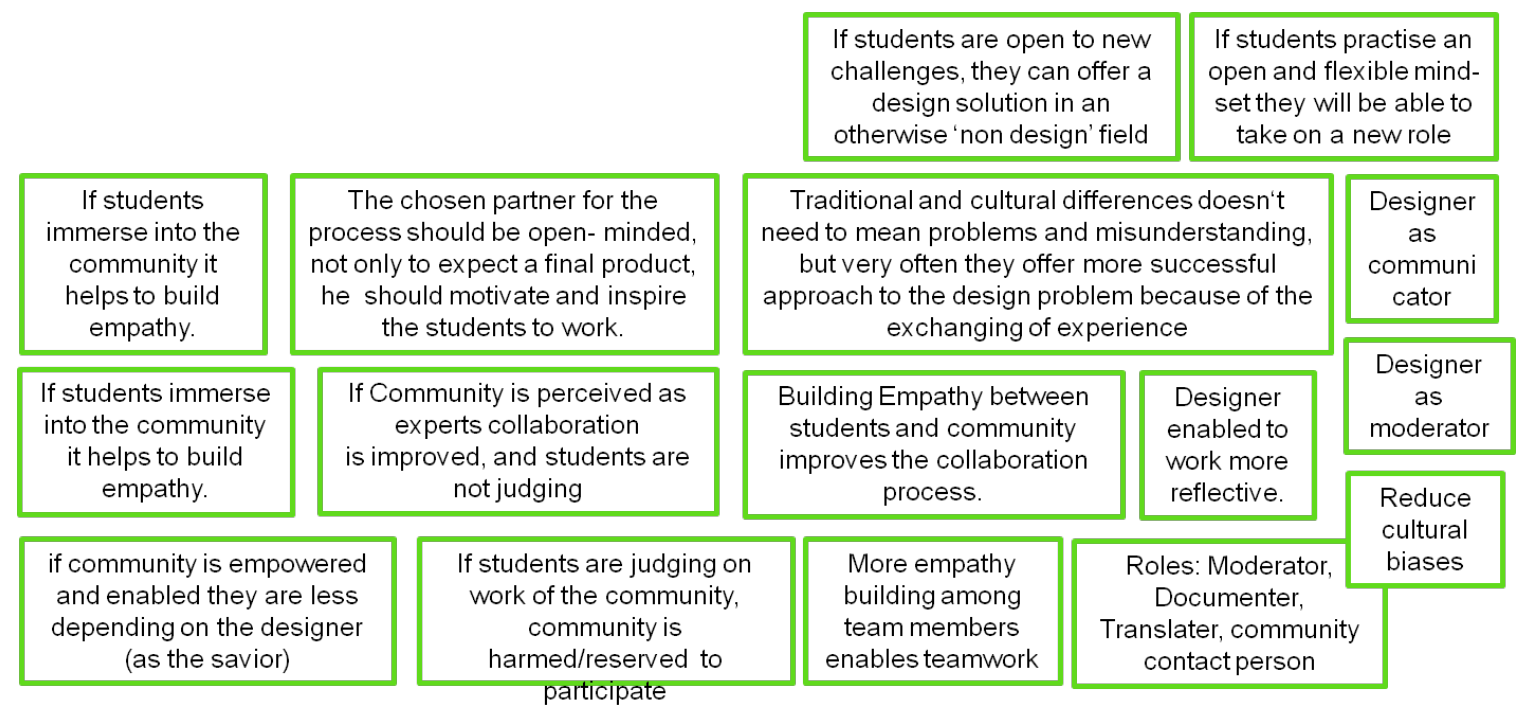

\section{Сл. 98 Хипотези во врска со начинот на размислување}

- Операција: Врски (Сл. 99)

If students understand the community they are working with, it will be easier to offer viable solutions

Understanding each
team member helps
in assigning roles

if students divide
roles within their
team it will be easier
for the community to
interact with them.

Building Empathy
between students and
community improves
the collaboration
process.

More empathy
building among
team members
enables
teamwork

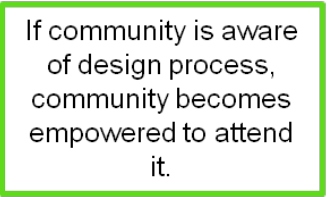

Embrace differences positively

If community is aware of design process and role of the designer, participation is more likely and higher

If students get to know each other better, they appreciate each other more and conflicts are reduced
Besides the community, students need to build empathy with each other so as to work effectively

Сл. 99 Хипотези за врските 
- Операција: Комуницирање (Сл. 100)

\section{If students understand the community they are working with, it will be easier to offer viable solutions}

\begin{tabular}{c|c|}
\hline $\begin{array}{c}\text { The ideas of the } \\
\text { If translation is } \\
\text { clearer thorugh } \\
\text { comunicattion with the } \\
\text { community }\end{array}$ \\
needed, it is \\
very important \\
to be done \\
immediately.
\end{tabular}

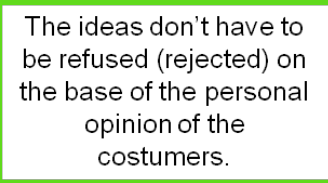

If Students are aware of teachers role and expertise and can benefit from it

\begin{abstract}
If the NGO partner or stakeholder presents ideas well, then the students are able to begin with the design process with generation ideas
\end{abstract}

If the teacher explain to the students at the beginning the reasons why they should use particular methods, they will be better prepared to start the process.
The teacher has to find the right questions in order to empower the right directions in the design process.
If community is aware of design process and role of the designer, participation is more likely and higher

\section{If translator is aware of} translation process (no interpretation) he is less likely to influence in one direction

\section{Сл. 100 Хипотези за комуникациски знаења}

- Операција: Соработка (Сл. 101)

\begin{tabular}{|c|c|c|c|c|c|c|}
\hline $\begin{array}{l}\text { Roles \& Wording } \\
\text { influences } \\
\text { expectations from } \\
\text { the community }\end{array}$ & $\begin{array}{l}\text { Reduce } \\
\text { cultural } \\
\text { biases }\end{array}$ & \multicolumn{2}{|c|}{$\begin{array}{l}\text { If students spend more } \\
\text { time with the } \\
\text { community, cultural } \\
\text { biases can be reduced }\end{array}$} & \multicolumn{2}{|c|}{$\begin{array}{l}\text { Students need to work } \\
\text { with the community } \\
\text { directly so as to offer } \\
\text { solutions }\end{array}$} & \\
\hline $\begin{array}{l}\text { Building Empathy } \\
\text { between students and } \\
\text { community improves } \\
\text { the collaboration } \\
\text { process. }\end{array}$ & $\begin{array}{l}\text { If groups are } \\
\text { smaller they } \\
\text { can work } \\
\text { more effective } \\
\text { (Macedonia) }\end{array}$ & \multicolumn{2}{|c|}{$\begin{array}{l}\text { Team more } \\
\text { effective if Roles } \\
\text { are based on } \\
\text { students discipline } \\
\text { and skills }\end{array}$} & \multicolumn{2}{|c|}{$\begin{array}{l}\text { if community is } \\
\text { empowered and } \\
\text { enabled they are less } \\
\text { depending on the } \\
\text { designer (as the savior) }\end{array}$} & $\begin{array}{l}\text { If students are judging } \\
\text { on work of the } \\
\text { community, community } \\
\text { is harmed/reserved to } \\
\text { participate }\end{array}$ \\
\hline $\begin{array}{l}\text { if community is } \\
\text { sensitized to the } \\
\text { design process, } \\
\text { they are more } \\
\text { willing to engage. }\end{array}$ & $\begin{array}{l}\text { If students } \\
\text { immerse into the } \\
\text { community it } \\
\text { helps to build } \\
\text { empathy. }\end{array}$ & \multicolumn{3}{|c|}{$\begin{array}{l}\text { The chosen partner for the } \\
\text { process should be open- minded, } \\
\text { not only to expect a final product, } \\
\text { he should motivate and inspire } \\
\text { the students to work. }\end{array}$} & \multicolumn{2}{|c|}{$\begin{array}{l}\text { If the students can } \\
\text { recognise the problems of } \\
\text { the community they can } \\
\text { start with generating ideas } \\
\text { instantly. }\end{array}$} \\
\hline $\begin{array}{l}\text { Through more frequent } \\
\text { meetings with the } \\
\text { community, more insights } \\
\text { can be generated }\end{array}$ & \multicolumn{2}{|c|}{$\begin{array}{l}\text { The ideas of the students } \\
\text { will get clearer thorugh } \\
\text { comunicattion with the } \\
\text { community }\end{array}$} & \multicolumn{3}{|c|}{$\begin{array}{l}\text { If students thorughly observe the } \\
\text { environment, they can recognise } \\
\text { problems that the community might } \\
\text { not be aware of. }\end{array}$} & $\begin{array}{l}\text { If students immerse } \\
\text { into the community } \\
\text { it helps to build } \\
\text { empathy. }\end{array}$ \\
\hline $\begin{array}{l}\text { Perception of the } \\
\text { environment leads to } \\
\text { better recognition of } \\
\text { the community } \\
\text { problems }\end{array}$ & $\begin{array}{l}\text { The ideas have to be } \\
\text { verified with early } \\
\text { prototypes before } \\
\text { shown to the } \\
\text { community }\end{array}$ & \multicolumn{2}{|c|}{$\begin{array}{l}\text { Discussion with } \\
\text { community lead to } \\
\text { better } \\
\text { understanding of } \\
\text { their problems. }\end{array}$} & \multicolumn{2}{|c|}{$\begin{array}{c}\text { Storytelling as an } \\
\text { important method to } \\
\text { explore opportunities } \\
\text { (share visions/future } \\
\text { scenarios) }\end{array}$} & $\begin{array}{c}\text { Presence of } \\
\text { instituations (NGOs) } \\
\text { at field research } \\
\text { harms participation on } \\
\text { eye level }\end{array}$ \\
\hline
\end{tabular}

\section{Сл. 101 Хипотези за соработка}




\section{- Диспозиција: Образование/Подготовка/Улоги? (Сл. 102)}

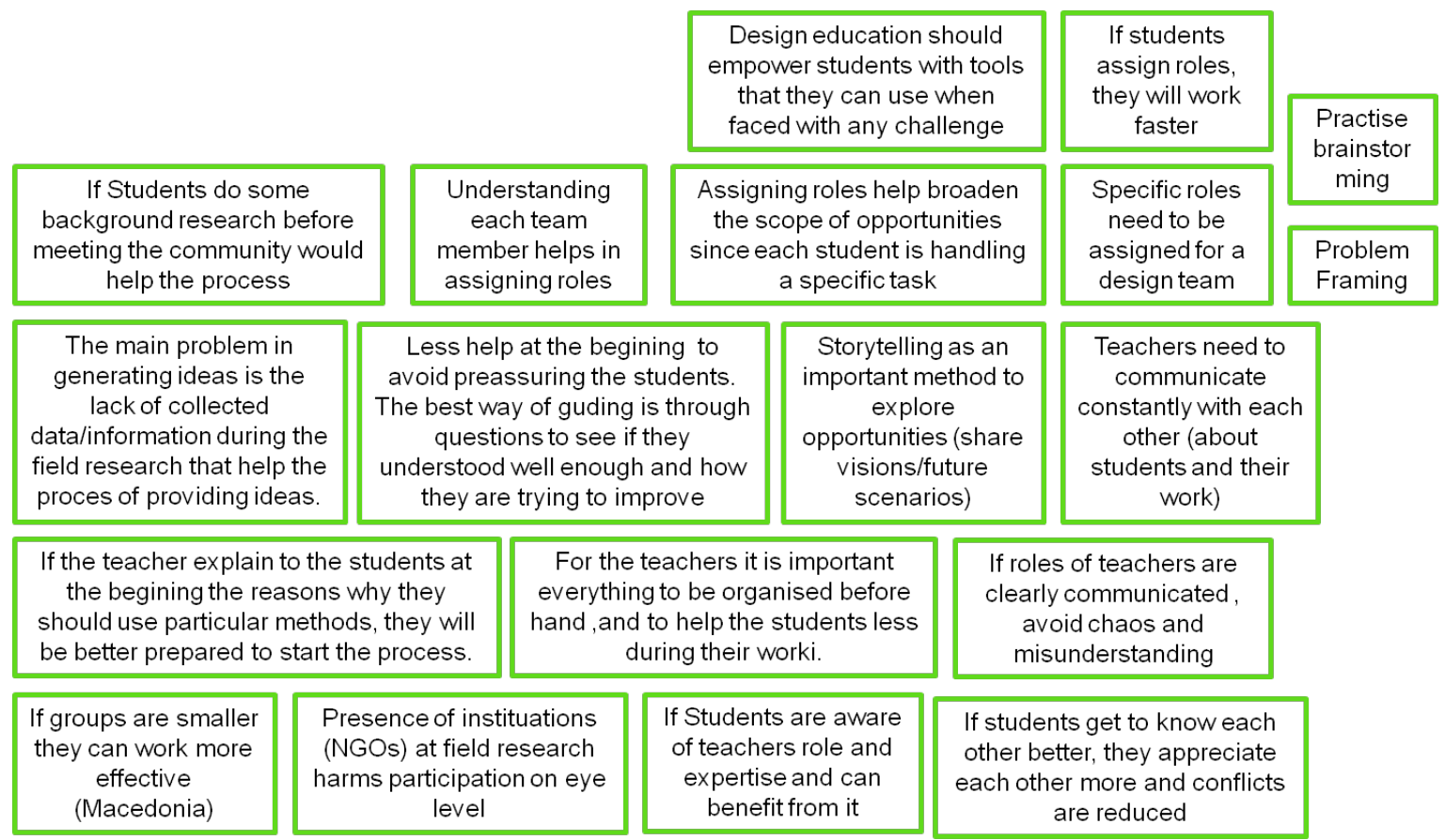

\section{Сл. 102 Хипотези за образование}

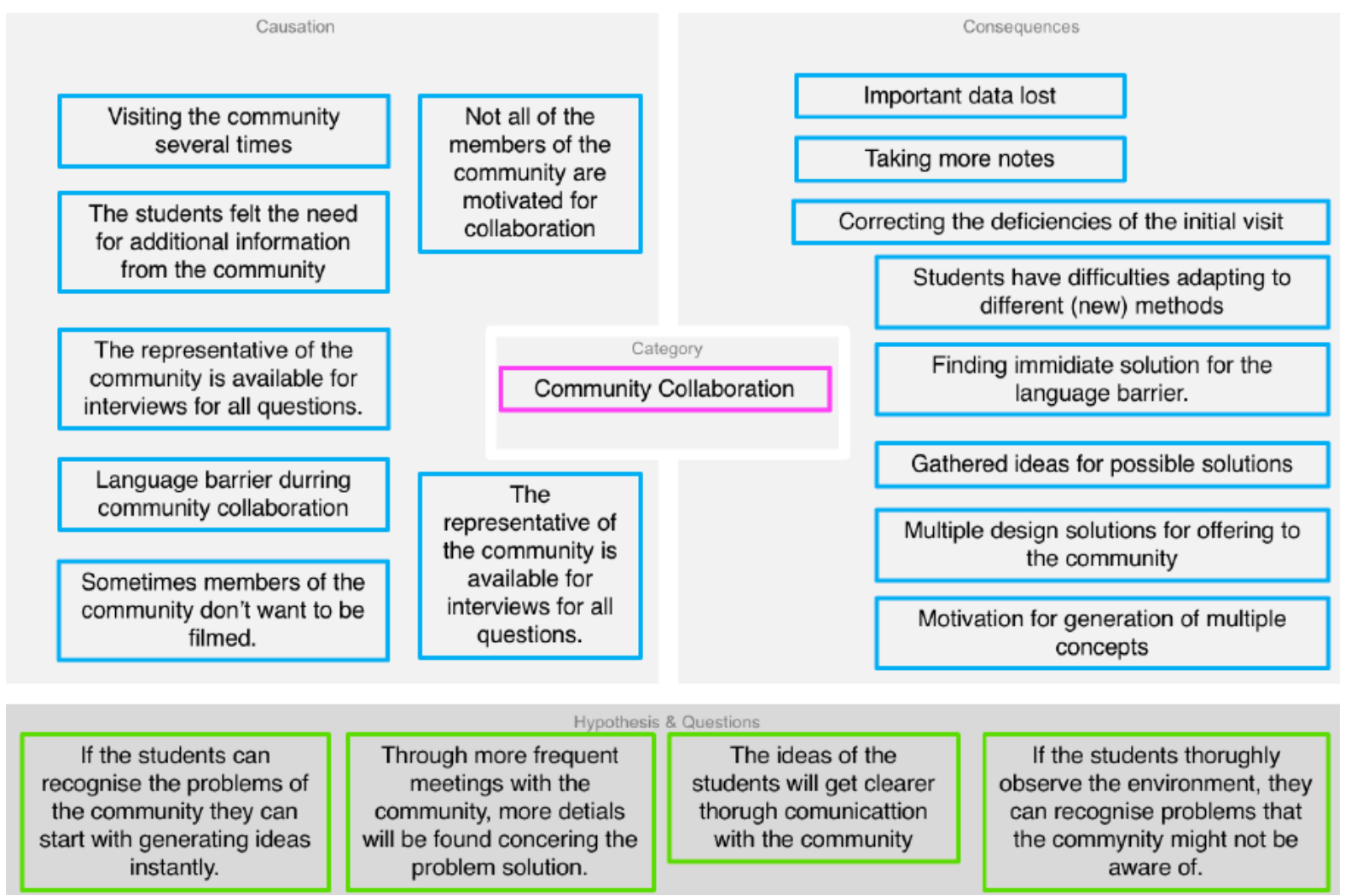

Сл. 103 Визуелизација на причинско последична зависност за категоријата соработка со заедницата според Втемелена теорија 


\section{Чекор 5. Теореми}

Истражувањето беше финализирано со формулирање на теореми базирани на хипотезите. Теоремите не содржат имиња, датуми и специфични описи на моменти, туку претставуваат толкување кое содржи учење. Тие беа применети како основа за подобрување на третата едукативна работилница во склоп на проектот „Дизајн со општествено влијание“ одржана во Мачакос, Кенија (Диј. 1).

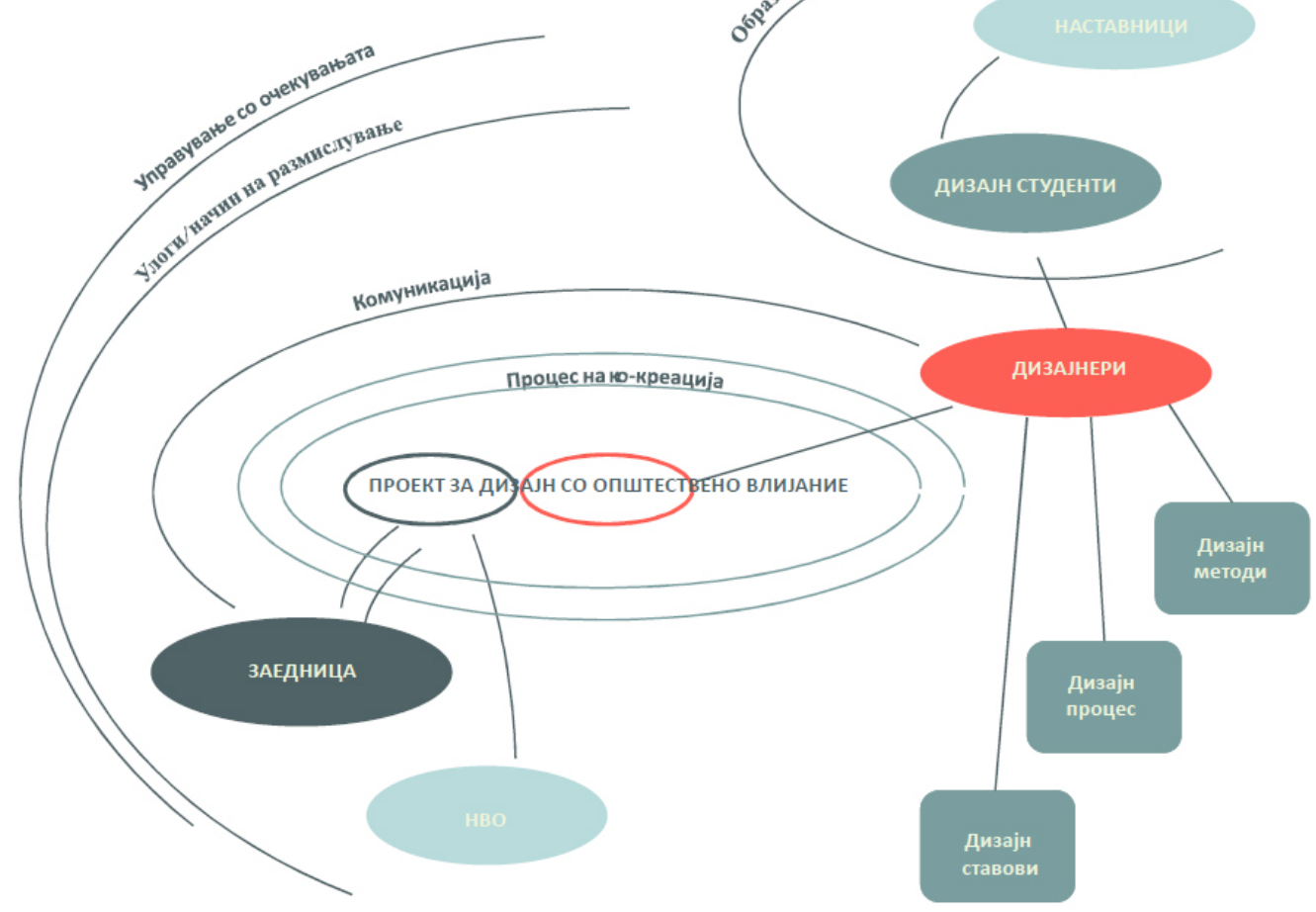

Диј. 1 Визуелизација на сите фактори во проект кој применува дизајн со општествено влијание

Настрана од проектот „Дизајн со општествено влијание“, ако теориите се читаат поопшто, може да дадат придонес во образованието за дизајн. Поради тоа истражувачкиот тим имаше потреба да ја види поголемата слика и да не се држи премногу за специфичните случаи од видео примероците. Формулирани се следните теореми: 


\section{ТеОРеМО 1 НАЧИН НА РАЗМИСЛУВАЊЕ И МЕКИ ВЕШТИНИ}

\section{основна теза}

Во процесот на социјален дизајн, дизајнерите (= учениците), членовите на заедницата и другите партнери треба да имаат отворено размислување за да постават основа за ко-креација.

под-тези

- На дизајнерите особено им е потребна емпатија кон заедницата за да ги разберат нивните потреби и да овозможат соработка.

- На заедницата особено и треба разбирање на сопствената креативна способност ("прави заедно" наместо "да се направи").

- Институционалните партнери / НВО имаат потреба од основно разбирање на дизајнот, начинот на размислување и неговата методологија.

- Во процесот на социјалниот дизајн, институционалните партнери / НВО играат важна улога. Улогата треба да се развива меѓусебно.

\section{Можни знаења}

Во процесот на социјален дизајн

- дизајнерите можат да стекнат свест за социјалните (на пример за социјалните потреби), можат да градат емпатија, можат да научат нови професионални улоги, можат да научат флексибилност и пристап за соработка со заедницата.

- Членовите на заедницата можат да стекнат свест за сопствената моќ / способност како дизајнери и ко-креатори.

- институционалните партнери можат да се запознаат со дизајнерското размислување, покрај тоа, да стекнат свест за нивното значење во косоздавањето.

\section{Теорема 2 КОМУНИКАЦИЈА И ЗБОРОВИ}

\section{основна теза}

Во социјален дизајн проект, важно е да се биде свесен за терминологијата и зборовите со цел да се зајакне меѓусебното разбирање и да се поддржи корисен начин на размислување кај сите присутни актери. Постојана комуникација на улогите, одговорностите и очекувањата се од суштинско значење за процесот на соработка при 
социјалниот дизајн. Улогата на преведувач при работата со различни националности има централна улога за да овозможи разбирање и комуникација.

\section{под-тези}

- Бидејќи комуникацијата во проект за социјален дизајн често е сложена и влијае на различни засегнати страни, треба да се обезбеди заеднички речник.

- Во проект за социјален дизајн, честите дизајн термини може да бидат погрешни и затоа треба да се ревидираат (на пример, брифинг, клиент итн.)

- Треба да се дискутира и да се дефинира комуникациска стратегија помеѓу сите учесници (ученици <-> студенти, студенти <-> заедница, студенти <-> институционални актери).

- Учење на раскажување приказни и прототипирање како метод помага при комуникацијата.

- Тимот треба да има преведувач, сензибилизиран и обучен така да држи секогаш објективна, неутрална позиција. Преводот треба да се врши во моментот, за да можат сите ученици да присуствуваат на разговорите со заедницата.

- НВО може да ја поддржи комуникацијата со заедницата преку запознавање.

\section{Теорема 3 односи и улоги}

\section{основна теза}

Во проект за социјален дизајн, секој од засегнатите страни / учесници / партнери мора да воспостават / развијат / дефинират / разберат и континуирано да ја одразуваат својата улога.

Во проект за социјален дизајн, успехот е цврсто поврзан со воспоставувањето на јасни улоги. Студентите треба да бидат сензибилизирани за нивните одговорности (Диј. 2). под-теза

- Во проект за социјален дизајн, улогите треба да бидат меѓусебно развиени и постојано испитани и рефлектирани.

- Во проект за социјален дизајн, моделите за улогата се различни / редефинирани / недефинирани во почетокот . 
- За секој проект, улогите треба да се дефинираат одново според околностите, не постои целокупен / општ рецепт.

- Методи и вежби за создавање емпатија можат да им помогнат на студентите да ги подобрат меѓусебните односи и односите со заедницата.

- Студентите треба да бидат охрабрени да ја напуштат својата зона на удобност и да преземат нови улоги и одговорности (надвор од нивната дисциплина).

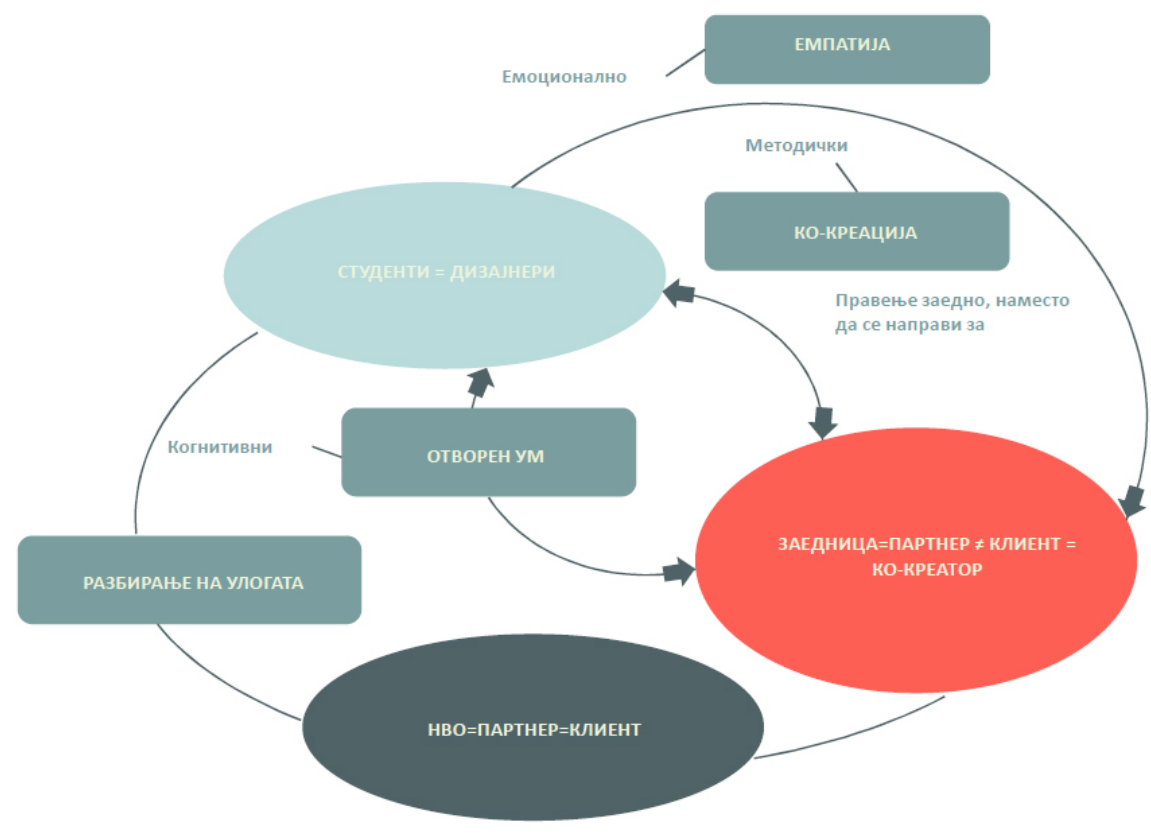

Диј. 2 Разбирање на односите и улогите на сите учесници во проект за дизајн со општествено влијание

\section{ТеОРеМа 4 СОРАБОТКА И ЗАЕДНИЦА}

\section{основна теза}

За да се подготви заедничката соработка, управувањето со очекувањата меѓу сите актери е многу важно за да се овозможи соработката. Изборот на заедниците и првите посети пред проектот можеби веќе создаваат очекувања.

под-теза

- Институционалниот тим треба да биде свесен и да разговара за приказната што им ја раскажува на членовите на заедницата поради управување со очекувањата.

- Студентите треба да практикуваат и да учат меки вештини (говор на телото, мислења и сл.) пред да се вклучат во соработка со заедницата. 
- Студентите треба да бидат обучени со социо-културно знаење во подготовката.

- Присуството на невладини организации и институции може да наштети на соработката со заедницата, бидејќи може да создаде погрешни очекувања.

- Заедницата треба да биде свесна за улогите на студентите за да се овозможи интеракција (Диј. 3).

- Заедницата треба да биде свесна за процесот на дизајнирање за да можат да присуствуваат.

- Заедницата треба да посвети време и интерес за соработка.

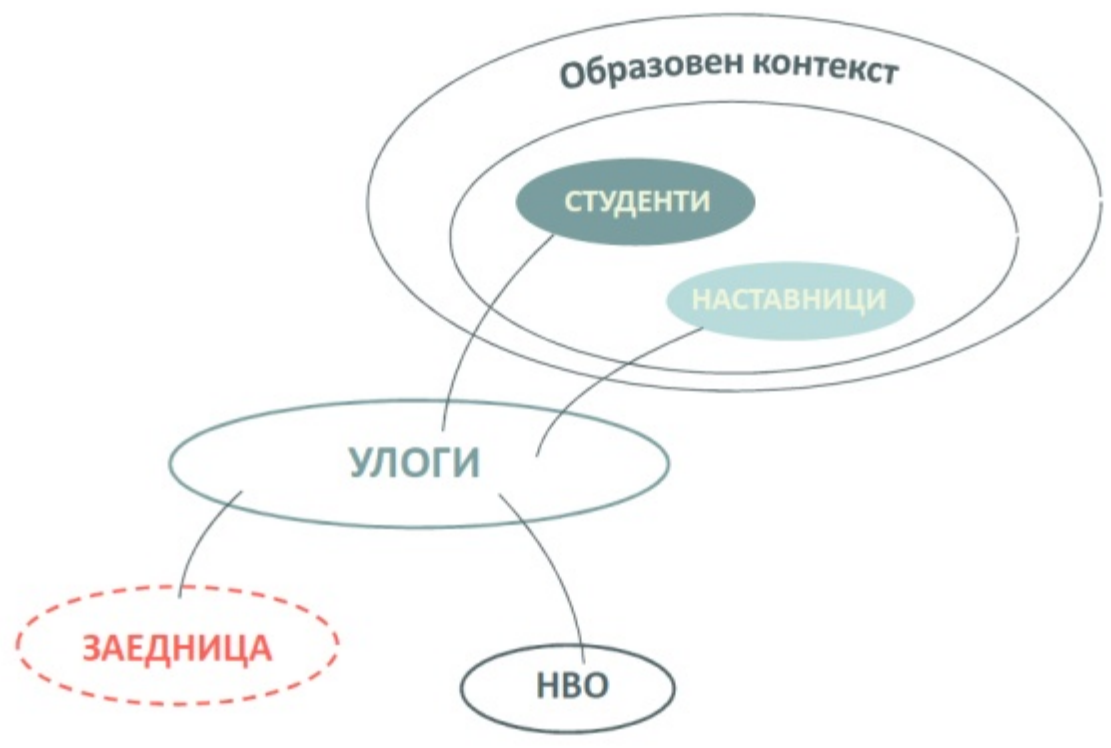

Диј. 3 Разбирање на улогите на сите учесници во проект за дизајн со општествено влијание

\section{Теорема 5 ОДНОСИ СО ЗАЕДНИЦАТА}

\section{основна теза}

За да се соработува со заедницата, потребно е да се обезбеди доволно време за градење на доверлив однос.

\section{под-теза}

- Студентските групи треба да бидат мали за да овозможат лични конверзации и доверба со заедницата.

- Потребен е постојан дијалог и комуникација помеѓу студентите и заедницата.

- Визуелната комуникација треба да се изучува (раскажување приказни, прототипови) за да се помогне соработката со заедницата. 
- Студентите треба да бидат охрабрени да ја набљудуваат околината и животната состојба на заедницата за да ја разберат поголемата слика.

\section{Теорема 6 ОБРАЗОВАНИЕ}

\section{основна теза}

Кога се учи социјалниот дизајн, најважно е да се нагласат разликите (во однос на методите, процесите, начинот на размислување и социокултурното знаење) помеѓу вообичаените процеси на дизајнирање и процеси на дизајнирање кај социјалниот дизајн.

\section{под-тези}

Наставата за социјален дизајн подразбира:

- воведување методи како што се набљудување, теренски истражувања, етнографија ( собирање на податоци);

- подобрување / вклучување на дизајнерски методи како што се раскажување приказни, визуализации, прототипирање;

- разбирање на социокултурните контексти и обука за емпатија;

- процесот е управуван преку итерација, а понекогаш дизајн процесите се хаотични;

- справување со отворена дефиниција на проблемот / уште не се дефинирани решенија / нејасни проблеми (нема прецизен брифинг);

- студентите треба да го научат методот на креирање проблеми, тие не добиваат класичен брифинг;

- ко-создавање со членови на заедницата непрофесионалци за дизајн;

- се справува со нејасни и сложени синџири на вредности;

- се работи по принципот на процес кој води одоздола-нагоре, наместо одозгора -надолу;

- подготвување на студентите да бидат флексибилни во својата улога;

- подготвување и сензибилизирање на студентите да бидат способни за управување со очекувања. 


\section{6 Споредбена анализа помеѓy регуларен процес на дизајнирање и процес на дизајнирање со општествено влијание}

На крајот од ова истражување, врз основа на извлечените хипотези и теореми, беше извршена споредба помеѓу особините на вообичаените процеси на дизајнирање и процесите на дизајнирање кај проекти кои поддржуваат дизајн со општествено влијание. Сличностите и разликите се визуелно презентирани во дијаграмот бр. 4 каде на левата страна се презентирани ставовите за вообичаен процес на дизајнирање, а на десната страна ставовите за процес на дизајнирање кај проекти од областа на дизајн со општествено влијание. Евидентно е дека и двата процеси ги следат вообичаените чекори, а се разликува прецизноста на дизајн брифингот, кој учествува во проектот, каква е улогата на учесниците во проектот, разлики во пристапот на согледување на причинско-последичните односи итн.

ДИЗАЈН ПРОЕКТ

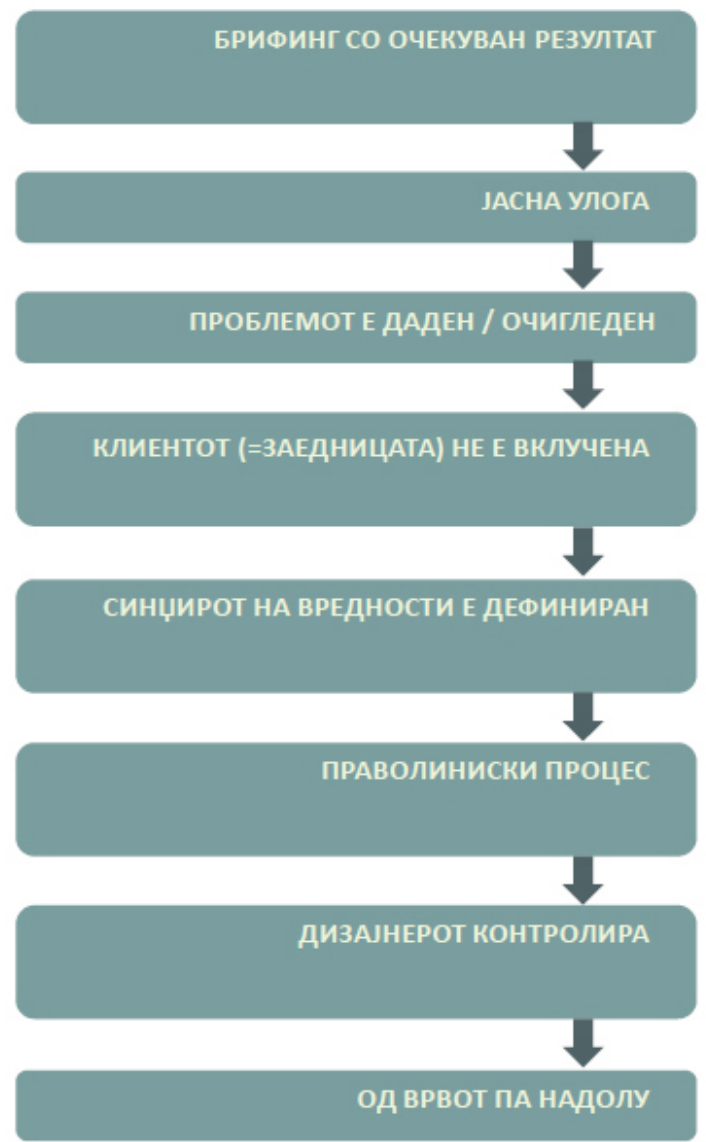

ПРОЕКТ ЗА ДИЗАЈН СО ОПШТЕСТВЕНО ВЛИЈАНИЕ

НЕМА БРИФИНГ / СЕУШТЕ НЕМА ДЕФИНИРАНО РЕШЕНИЕ

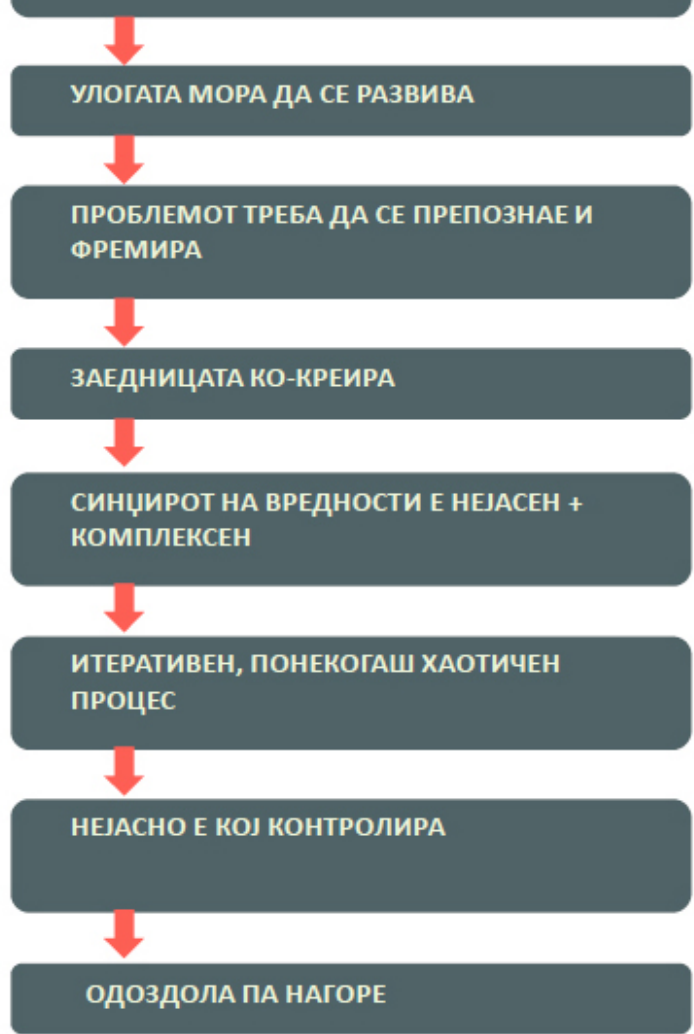

Диј. 4 Споредба на вообичаен дизајн проект со проект за дизајн со општествено влијание 


\section{7 Како се реализира проект од областа на дизајн со општествено влијание}

Како резултат на стекнатите искуствата од едукативниот и истражувачкиот дел на проектот „Дизајн со општествено влијание“ станува сосема појасна целокупната структура на еден проект во кој се применува пристап на дизајн со општествено влијание. Овој вид проекти имаат многу покомплексна структура и содржина од вообичаениот проект за дизајнирање (Диј. 5). Таа се состои во следните важни аспекти:

- Учесници - вообичаено се вклучени од една страна засегнатата заедница, од друга страна дизајнер (или тим од дизајнери), а врската помеѓу нив ја воспоставува невладина организација.

- Начин на соработка - основа на овој пристап е процесот на ко-креирање.

- Дизајнерите се професионалци кои ракуваат со креативни техники, методи на дизјанирање. Им недостасува свест за улогата која можат да ја имаат во општеството. При учество во ваков проект неопходно е да воспостават емпатија со членовите на засегнатата заедница заради подобра соработка и подобри резултати.

- Членовите на засегнатата заедница имаат улога на специјалисти во нивната област - секојдневна работа или професија. Тие поседуваат индивидуално знаење кое може да биде од пресудно значење во процесот на ко-креирање. Tие не се свесни за моќта на ко-креирањето, како комбинација на нивното и знаењето на дизајнерите.

- Невладините организации ги немаат знаењатата на дизајнерите, ниту на членовите на заедниците. Но, нивната улога е да ги препознаат засегнатите заедници и нивните проблеми и да ги поврзат со дизајнерски тимови кои имаат знаење $и$ ја познаваат методологијата на дизајн со општествено влијание. Тие се медијатори во процесот, нивната цел е да помогнат во поврзување на двете страни заради ко-креирање чиј резултат е решение на проблемите на заедницата. 
- Важен аспект на овој процес е разбирањето на улогите на сите учесници, можноста за нивно прилагодување на условите, отвореноста за прифаќање нови предизвици, стекнување нови знаења и нивна примена.

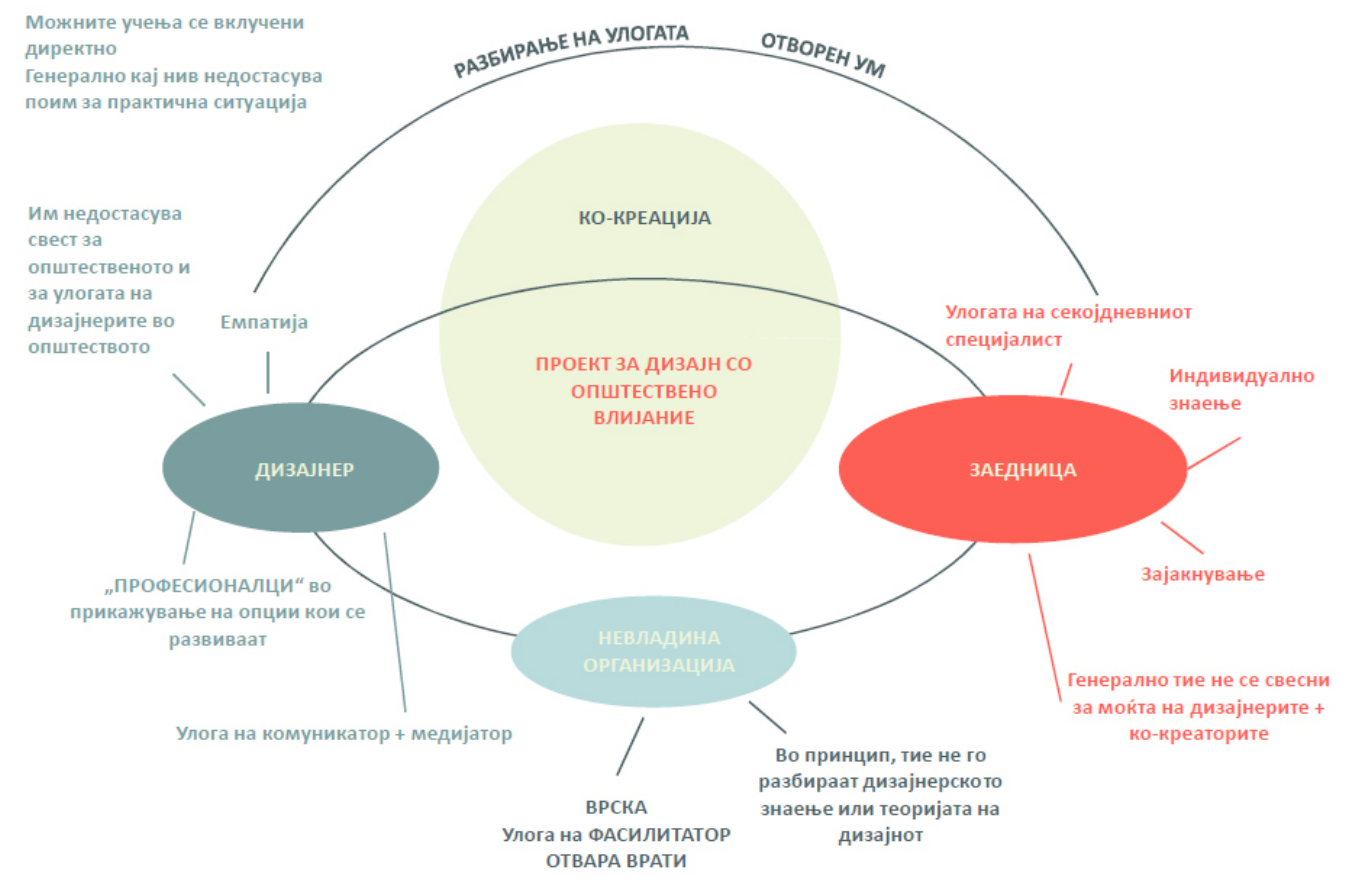

Диј. 5 Визуелизација на целокупниот процес на реализација на еден проект за дизајн со општествено

$$
\text { влијание }
$$

\section{8 Придобивки од извршеното истражување}

На крајот на ова истражување може да се заклучи дека стекнатите придобивки од него можат да се забележуваат во неколку аспекти (диј. 6):

- Од една страна беа применети современи истражувачки методи (етнографско истражување и втемелена теорија) кои овозможија да се извлечат важни заклучоци во вид на хипотези и теореми.

- Хипотезите и теоремите, од друга страна, се применливи како методи во процесот на дизајнирање, во вид на процедури, алатки и правила. На тој начин тие директно влијаат во унапредување на меките вештини и дидактичките едукативни методи.

- Овие резултати истовремено имаа и рефлективна улога за унапредување на начинот на размислување на сите вклучени учесници. 


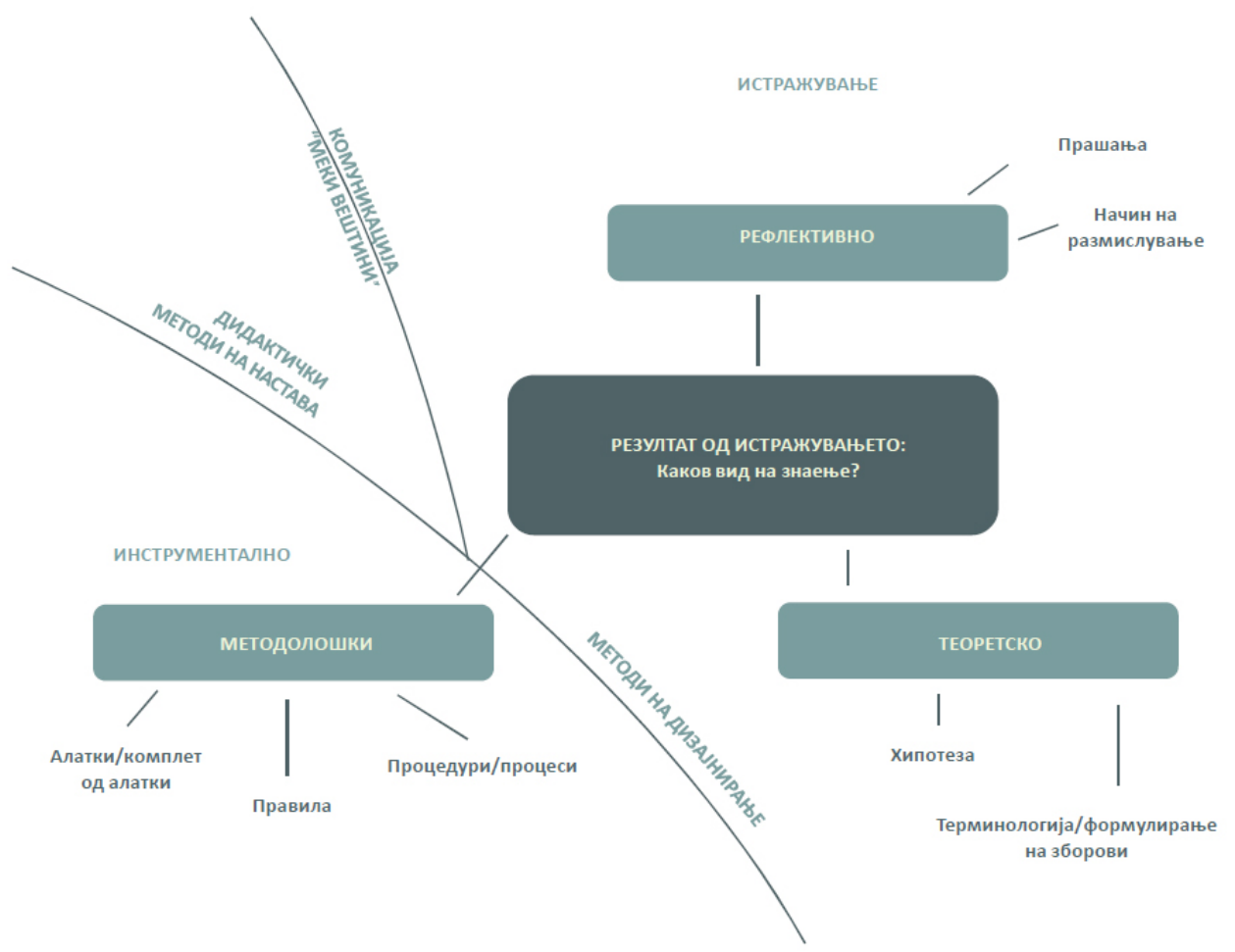

Диј. 6 Придобивки од извршеното истражување 


\section{6. Анализа на состојбите во нашето општество и анализа на можностите за примена на методологијата дизајн со општествено влијание заради нивно подобрување}

Главната цел на моето истражување е проучување на суштината на пристапот општествено влијание на дизајнот и нејзиното значење во современото општество, да се проучат методите што произлегуваат од него и конечно да се даде придонес за промовирање, ширење и примена на знаењата и искуствата од реализираните активности од оваа област во нашето општество. За таа цел извршив анализа на моменталните состојби во Македонија во сите области на општествениот живот. На крајот на ова поглавје се презентирани во кратки црти најважните сегменти во нашето општество во кои примената на методологијата дизајн со општествено влијание би можела да даде голем придонес за нивно подобрување.

\section{1 Загадување на околината}

Сведоци сме на исклучително високо загадување на воздухот во нашите градови. Оваа зима се искачивме повеќепати на прво место во светот по загадување на воздухот.

Освен тоа, немаме систем ниту култура за селекција на отпадот од домаќинствата. Собирањето на отпадот во контејнери кои никој не ги затвора, собирање на животни скитници околу нив, расфрлање на сметот наоколу, преполни контејнери. Во некои градови не постојат соодветно организирани депонии. Честопати оптадот се гори и дополнително го загадува воздухот.

Голем број индустриски капацитети не располагаат со соодветни системи за филтрирање.

Ова е само мал дел од проблемите во оваа област. Уште голем број стојат нерешени и лошо организирани. 


\section{2 Политичка состојба}

Редовните конфликти меѓу владата и опозицијата кои прераснуваат дури и во политички реваншизам постојано ја туркаат државата во политички кризи. Честопати тие политички кризи не се решаваат со разговор туку нивното решение се бара преку организирање на протести кои и неретко се случува да бидат насилни.

Прекршувањето на законите и на етичките стандарди, проследени со корупција и криминал, партиски вработувања и непотизам, лесно поминува недетектирано, а кога некој прекршок ќе се обелодени се чини дека не е реткост да се избега од одговорноста и да не се одговара пред законот. Влијанието на политиката во медиумите и правниот систем само дополнително ја влошува таа состојба.

Се спроведуваат реформи, меѓутоа сведоци сме на кршење на демократијата, погрешни политики, вработување на несоодветен кадар, неостварени ветувања, несоодветно менаџирање на буџетски средства. Најмногу успех се бележи кога се работи за личен, а не за државен интерес и кога треба да се соберат политички поени пред предвремени и редовни избори.

Како да не е доволна непрегледната и нестабилна политичка состојба, народот дополнително ја влошува состојбата со тоа што се преокупира со политиката и се дефокусира од индивидуалниот придонес за нашето општество.

\section{3 Социјална политика}

Сиромаштијата ја чувствуваат голем број граѓани, голем е процентот на невработеност, секојдневно среќаваме бездомници. Тешко е да се сретне човек кој не се жали на животниот стандард без разлика на неговата лична финансиска состојба. Тие, како и многу други причини предизвикуваат масовна имиграција на луѓе надвор од Македонија.

Државата воведува мерки за решавање на тие проблеми, меѓутоа не се забележуваат значителни резултати. Се прават напори тие мерки да бидат блиски за граѓаните и соодветни за нивните потреби, меѓутоа воопшто не се поттикнува 
целокупното население да даде директен придонес во решавањето на социјалните проблеми.

\section{4 Односи во семејствата}

Семејните односи во Македонија се наоѓаат во криза која е предизвикана најмногу од бројни негативни трендови, како и од целокупната состојба во државата. Тоа го потврдуваат статистичките податоци кои покажуваат дека секоја година се склучуваат се помалку бракови, а се зголемува бројот на разводи и вонбрачни деца. Финансиските кризи го одложуваат стапувањето во брак и формирање семејства, а ги нарушуваат семејните односи во веќе формираните семејства.

Невработените лица се дополнителен финансиски терет на другите членови од нивните семејства. Се повеќе семејства живеат разделени поради имиграцијата во потрага по подобар живот.

Сето тоа доведува до појава на конфликти, депресија, семејно насилство, недоволно заемно почитување, полова нееднаквост и тн.

\section{5 Демографска состојба}

Македонија е мултиетничко општество со неколку религии во кое се зборуваат повеќе јазици, па често се јавуваат конфликти помеѓу различни националности предизвикани од етничките, културните и образовните разлики.

Слабата економија и сиромаштијата предизвикуваат масовна имиграција на младите луѓe, а со зголемената возраст на стапување во брак се намалува бројот на новороденчиња, резултатот е забрзано стареење на нацијата.

Непостоењето на тековен попис дополнително ја влошува состојбата поради тоа што се носат одлуки за нејзино подобрување врз база на неточни и датирани податоци. 
6.6 Анализа на предностите, слабостите, можностите и заканите во нашето општество (SWOT анализа)

Како заклучок на ова поглавје целокупната состојба во нашето општество е презентирана во дијаграмот бр. 7 од кој може да се извлечат заклучоци дека нашето општество има голем потенцијал за напредок поради природните богатства и ресурси.

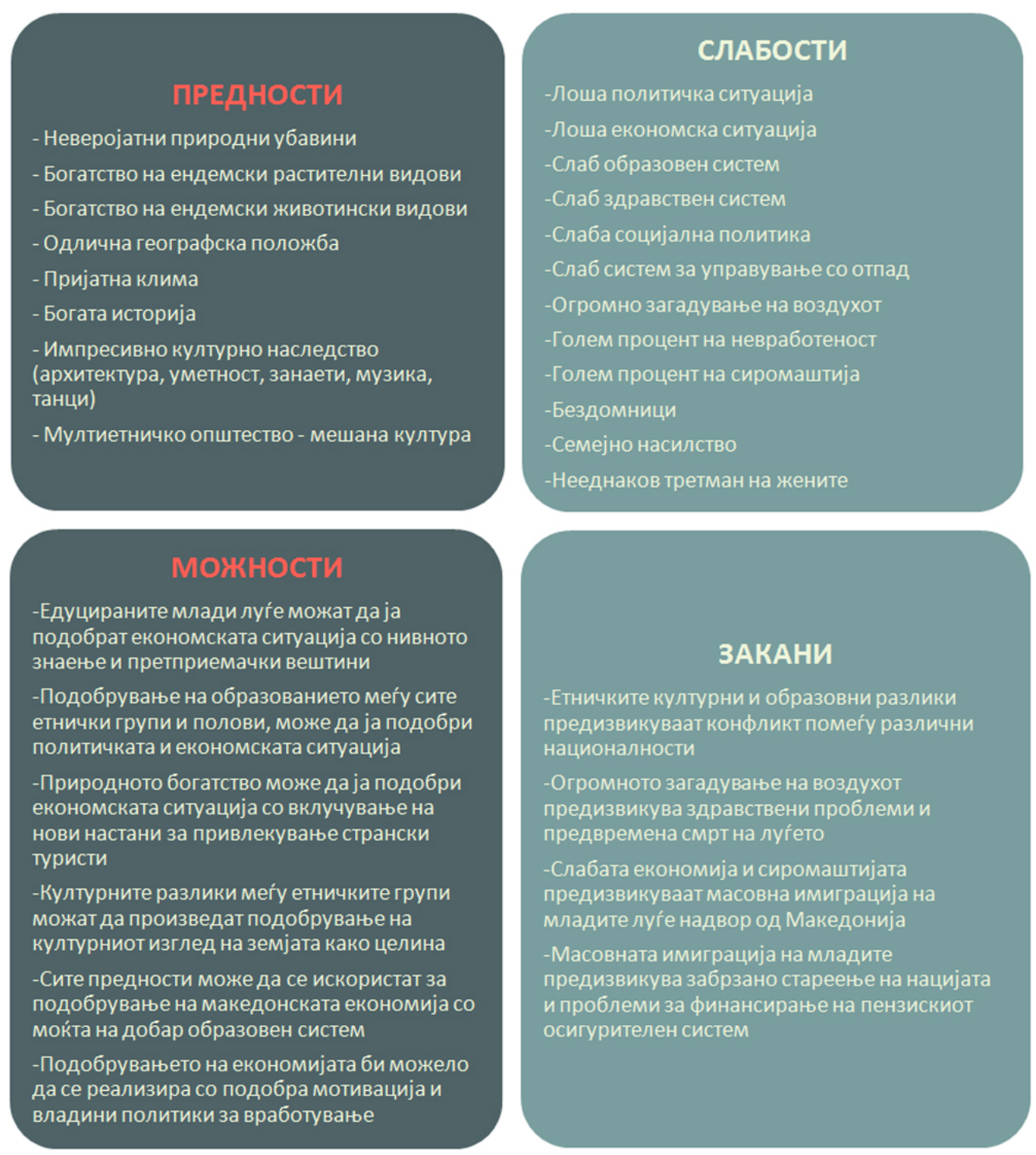

Диј. 7 SWOT анализа 
Слабостите и заканите во овој момент се бројни, но со добра организација на сите сили во општеството, особено енергијата и знаењето на младината, може да се надминат и да се подобрат. За таа цел знаењето е неопходен инструмент. Познавањето на методологијата на дизајн со општествено влијание и искуството на директните учесници во процесот на нејзината разработка и унапредување може да биде од големо значење за подобрување на состојбите во нашето општество. Токму затоа ширењето на свеста за моќта на оваа методологија, за моќта на креативните техники во сите пори на општеството е дефинитивно неопходна.

Најсоодветен и најдостапен медиум за ширење на овие сознанија до пошироките општествени слоеви е интернетот. Поради тоа, крајна цел на овој магистерски труд е да понуди веб платформа преку која ќе биде реализирана оваа потреба. Нејзиното постоење со можност за збогатување со нови сознанија и искуства од реализирани работилници, можноста за препознавање на нови проблеми, можноста за организирање на сите расположиви сили преку формирање тимови за решавање на проблемите би била од голема корист за нашето општество. 


\section{7. Дефинирање на структурата на концепт дизајн на веб платформа за промовирање на методологијата дизајн со општествено влијание}

Анализата на реализираните работилници резултираше со заклучоци за моќта на методологијата дизајн со општествено влијание и нејзиното значење во современото општество. Како директен учесник во едукативниот и истражувачкиот дел од проектот „Дизајн со општествено влијание“ имам морална обврска да ги пренесам стекнатите знаењата и да се обидам да ги направам достапни до пошироката јавност во нашето општество. Мојот придонес при тоа би бил најдобро реализиран со изработка на вебплатформа наменета за промовирање на методологијата дизајн со општествено влијание во нашата средина со цел подигање на свеста за значењето на дизајнерите и креативниот начин на размислување како важен фактор за решавање на бројни проблеми во современите заедници и современото живеење.

Веб платформата треба да овозможи:

- размена на сознанијата помеѓу дизајнерите кои ги искусиле придобивките на применетите методи на дизајнирање со општествено влијание;

- засегнати општествени групи да ги презентираат своите проблеми за кои имаат потреба од соодветна помош;

- вклучување на невладини организации кои ќе дадат свој придонес во поврзување на препознаените општествени проблеми со стручни тимови кои имаат знаење и умешност како да се помогне во решавање на истите.

\section{1 Таргет групи на корисници}

Како целна група на корисници за веб платформата може да се сметаат сите кои имаат потреба од промовирање, ширење и примена на знаења и искуства од областа на опшествениот дизајн. Тоа може да бидат: граѓани, дизајнери, невладини организации, разни други организации, образовни институции, компании и заедници. Заради појасна претстава за потребите на дизајнот на веб платформата попрецизно се дефинирани следните категории корисници:

- Дизајнери и други креативци кои имаат искуство во примена на методи на дизајнирање со општествено влијание 
- Дизајнери и други креативци кои сакаат да стекнат искуство во примена на методи на дизајнирање со општествено влијание

- Невладини организации и други институции кои работат на проекти за решавање на различни општествени проблеми

- Поединци или социјални групи кои имаат потреба од стручна помош за решавање на конкретни проблеми

\section{2 Основни барања за дизајнот на веб платформата}

Како во секој процес на дизајнирање на било кој производ неопходно е прецизно дефинирање на основните и посебните барања. Најчесто тие се дефинираат врз основа на извршени анкети и квалитативни истражувања помеѓу претставници на таргет групите. Во овој случај го применувам моето искуство во проектот во кој бев набљудувач на сите настани. Тоа ми овозможи да ги согледам потребите и барањата на сите засегнати страни. Конечно, листата се состои од следните барања:

- Дизајн кој привлекува внимание;

- Дизајн кој ја презентира водечката поента на темата на прв поглед;

- Добри слогани на тема решавање општествени проблеми заради привлекување на засегнати групи или поединци;

- Потенцирање на моќта на креативното размисливање и методологијата дизајн со општествено влијание;

- Да обезбеди интерактивност со корисниците - можност за поставување нови искуства од реализирани проекти, пријавување на нови социјални проблеми проблеми, размена на информации за формирање тимови со стручни лица од разни професии, како и додавање на коментари и забелешки за презентираните податоци на оваа веб платформа;

- Да содржи што повеќе базични информации и објаснувања за методологијата дизајн со општествено влијание;

- Да овозможи класификација на собраните информации (проекти, проблеми, профили на стручни лица);

- Добра навигација низ страниците на веб платформата;

- Примена на Responsive design - можност за прегледување на различни уреди за отварање интернет (РС компјутер, лап топ, таблет, мобилен телефон). 


\section{3 Структура на податоците}

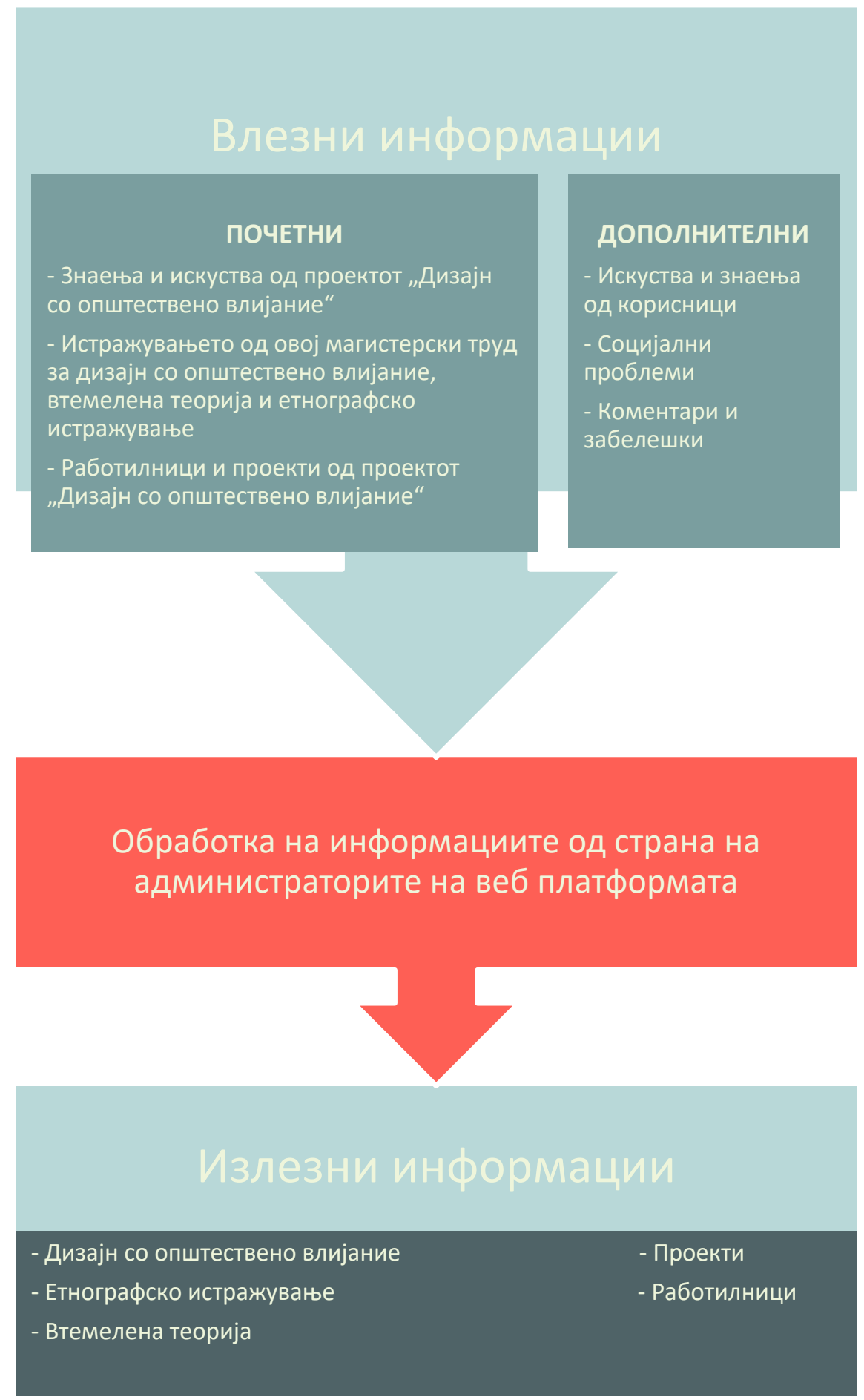

Диј. 8 Влезни и излезни информации за веб платформата

Со цел да се направи добра организација на неопходните податоци за креирање на веб платформата беше неопходно прецизно да се дефинираат сите видови податоци влезни и излезни (Диј. 8). Собирањето и организирањето на сите материјали за изработка на веб платформата бараа сериозен пристап. Реализираните работилници 
во Скопје и Мачакос генерираа огромен број материјали за документирање на проектите во вид на текстови, слики, дијаграми, видео снимки итн. Сите тие бараа детално и прецизно подредување и сместување во добро организирани фолдери, достапни за презентирање на веб платформата.

\section{4 Структура на веб платформата}

Веб платформата е креирана како систем од неколку поврзани страници. На дијаграмот бр. 9 е презентирана детално структурата на веб платформата.

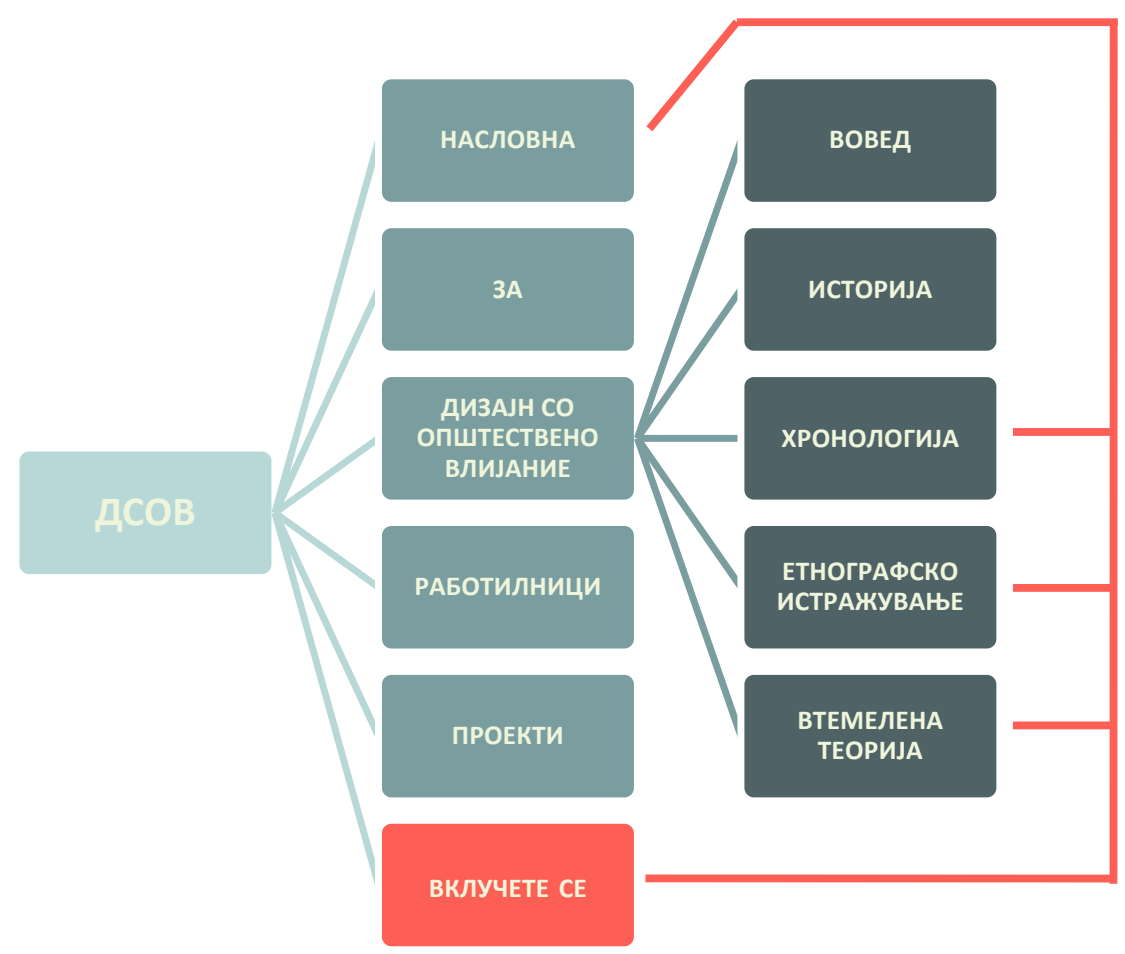

Диј. 9 Структура на веб платформата 


\section{8. Детална презентација на разработениот концепт дизајн на веб платформа}

Врз основа на дефинираните барања за концептот на веб платформа за промовирање на методологијата дизајн со општествено влијание се пристапи кон изработка на истата.

\section{1 Избор на софтвер за изработка на веб платформата}

Веб платформата е изработена со примена на слободниот онлајн софтвер WordPress кој служи за изработка на веб страници преку систем за менаџирање на содржини базиран на PHP и MySQL. WordPress е најпопуларна платформа од овој тип на која во моментот се базирани повеќе од 60 милиони веб страници (сл. 104). Се карактеризира со користење на тематски систем и плагин архитектура.

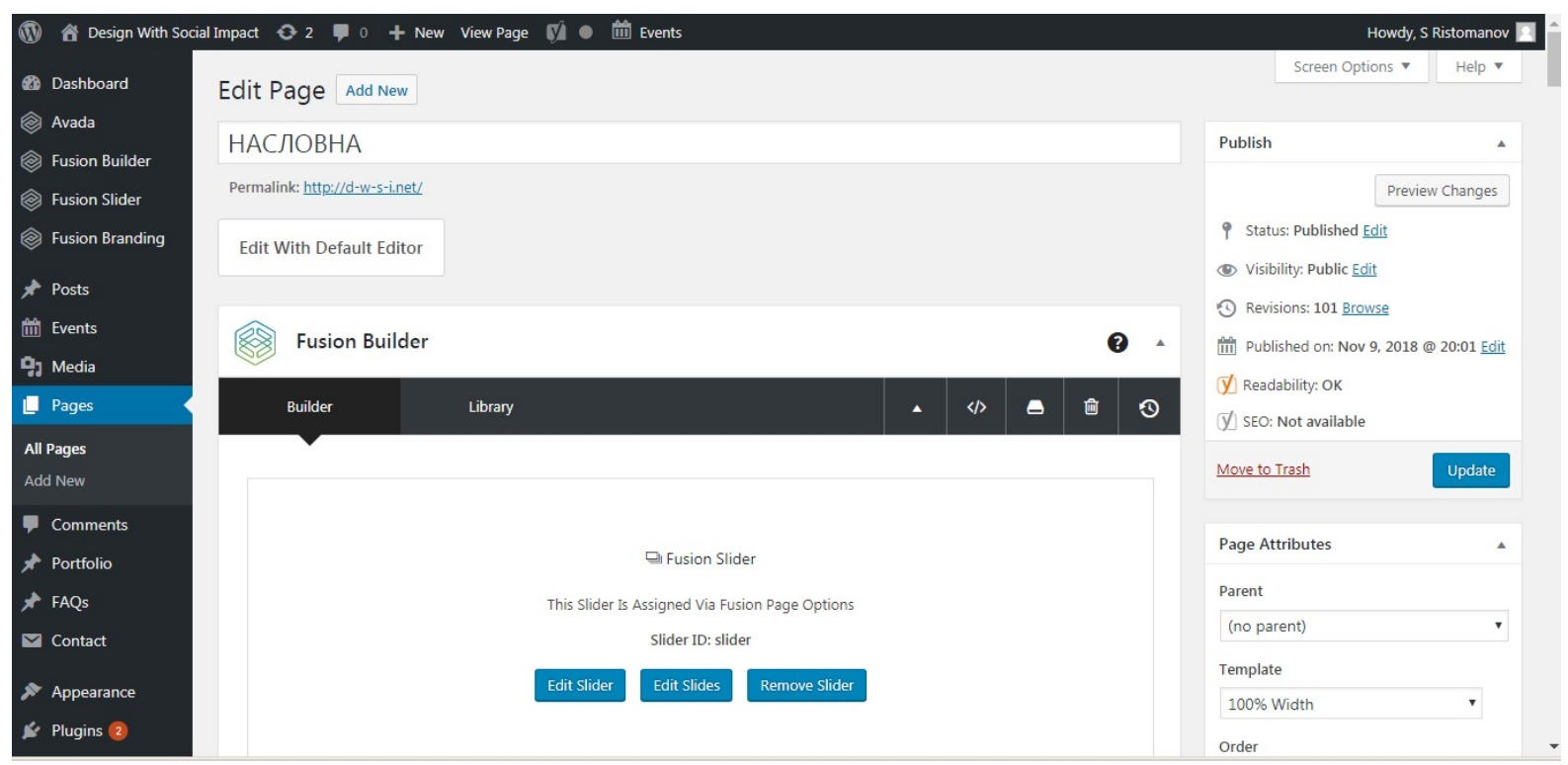

Сл. 104 Приказ од контролниот панел на WordPress

\section{2 Избор на тема за дизајнот на веб платформата}

Темата Avada е избрана како основа за изработка на веб платформата, чиј прилагодлив дизајн одговара на барањата кои треба да се задоволат. Avada е тема 
која е моментално најбарана на пазарот бидејќи е најкомплетно развиена во однос на останатите теми. Таа содржи моќни карактеристики, опции и алатки кои овозможија квалитетна реализација на дизајнот на оваа веб платформа. На слика 105 се презентирани дел од понудените теми на Avada од кои е извршен конечниот избор. Избраната тема најблиску ги задоволува претходно поставените барања за дизајнот на веб платформата.

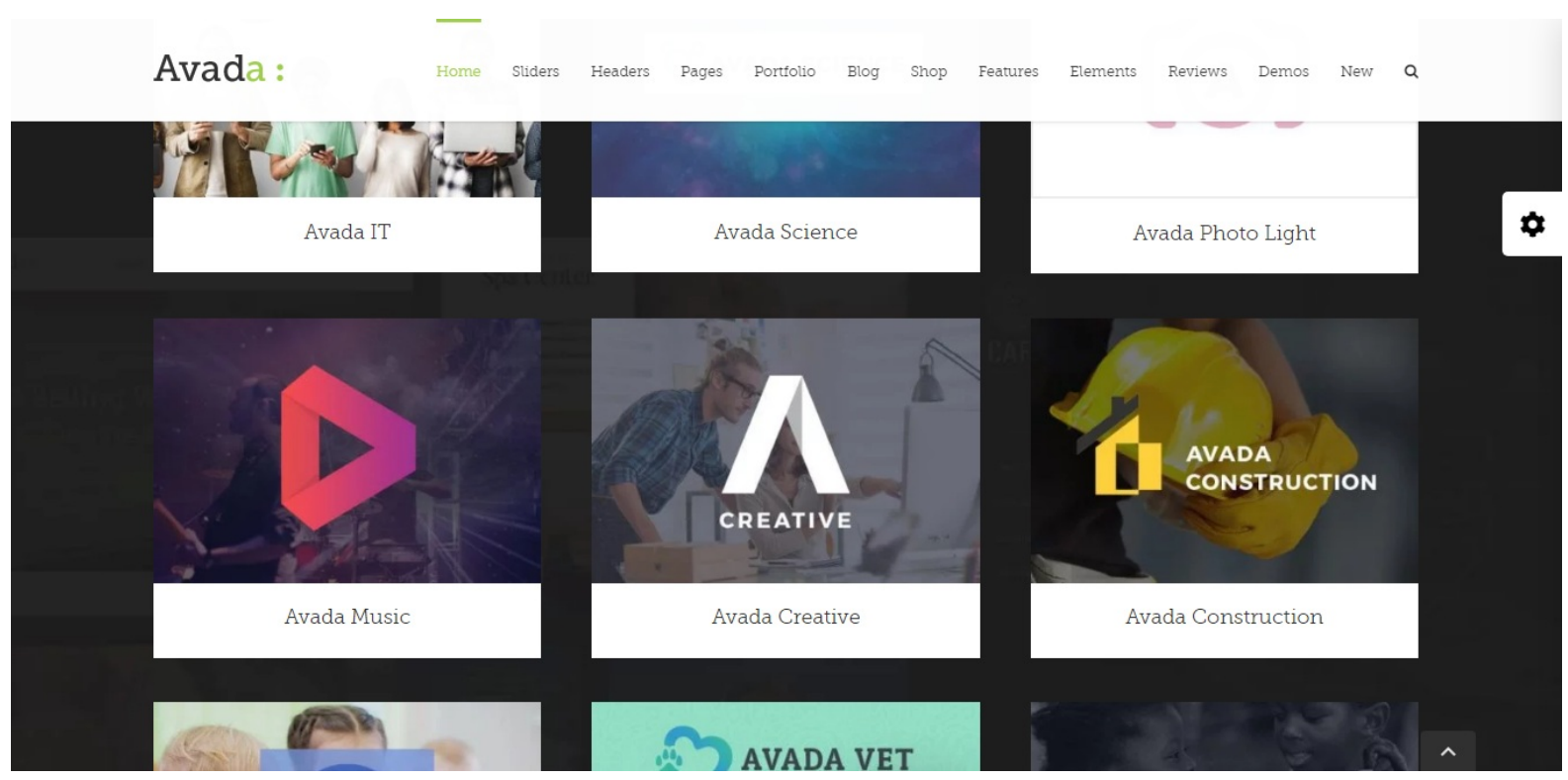

Сл. 105 Avada теми за WordPress

Поради начинот на кој функционира WordPress co плагин архитектура, неопходно беше да се користат и одредени плагини кои се компатибилни co Avada, a со цел да се овозможи реализација на посакуваниот дизајн на веб платформата (сл. 106). 


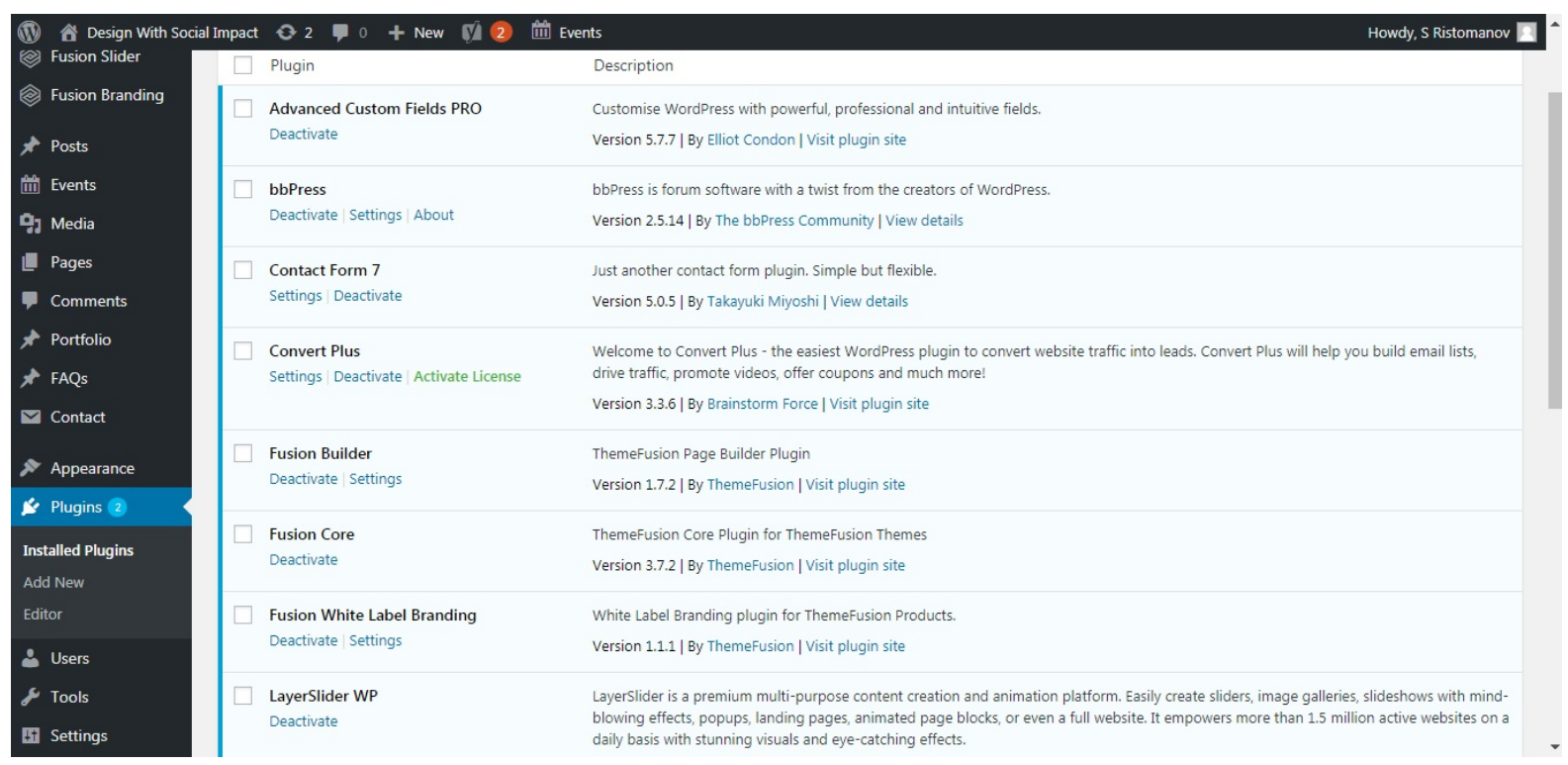

Сл. 106 Дел од инсталираните плагини за овозможување соодветни функции на веб платформата

\section{3 Избор на домен}

Откако беше извршен избор на платформа за развој и тема, следеше подесување на основните параметри за истите, како и нивно прикачување онлајн со домен и хостирање. Доменот беше избран по насловот на пристапот „Дизајн со општествено влијание“, односно од истоимениот наслов на англиски јазик „Design With Social Impact" беа земени само првите букви од зборовите и се доби следното: www.d-w-s-i.net.

\section{4 Избор на палета на бои}

Изборот на палетата на бои (Сл. 107) за веб платформата мора да соодветствува на намената на веб платформата. Се работи за сериозна тема и сериозни корисници, така што во избраната палета треба да доминираат ладни бои. Избрани се неколку нијанси на сината боја која е позната како боја која буди доверба од психолошки аспект, делува елегантно, формално и серизно. Додадена е црвено-виолетова боја, на граница помеѓу топла и ладна, која делува освежувувачки во комбинација со неколкуте нијанси на сина боја. 


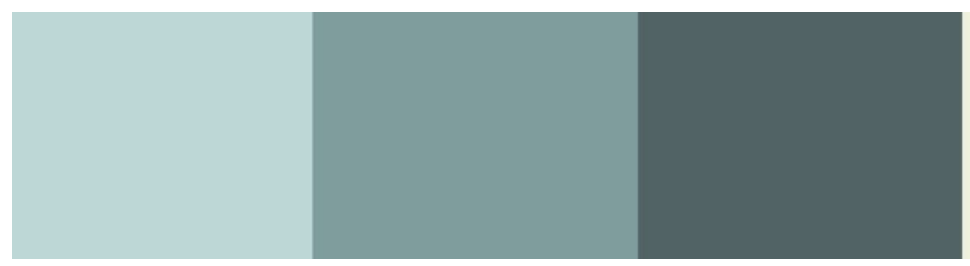

Сл. 107 Избрана палета на бои за дизајнот на веб платформата

\section{5 Дизјан на поединечните страни на веб платформата}

Врз основа на претходно дефинираните барања беше пристапено кон изработка на страниците на веб платформата наменета за промовирање на методологијата дизајн со општествено влијание преку презентирање на знаењата и искуствата од проектот „Дизајн со општествено влијание“ и истражувањето од овој магистерски труд.

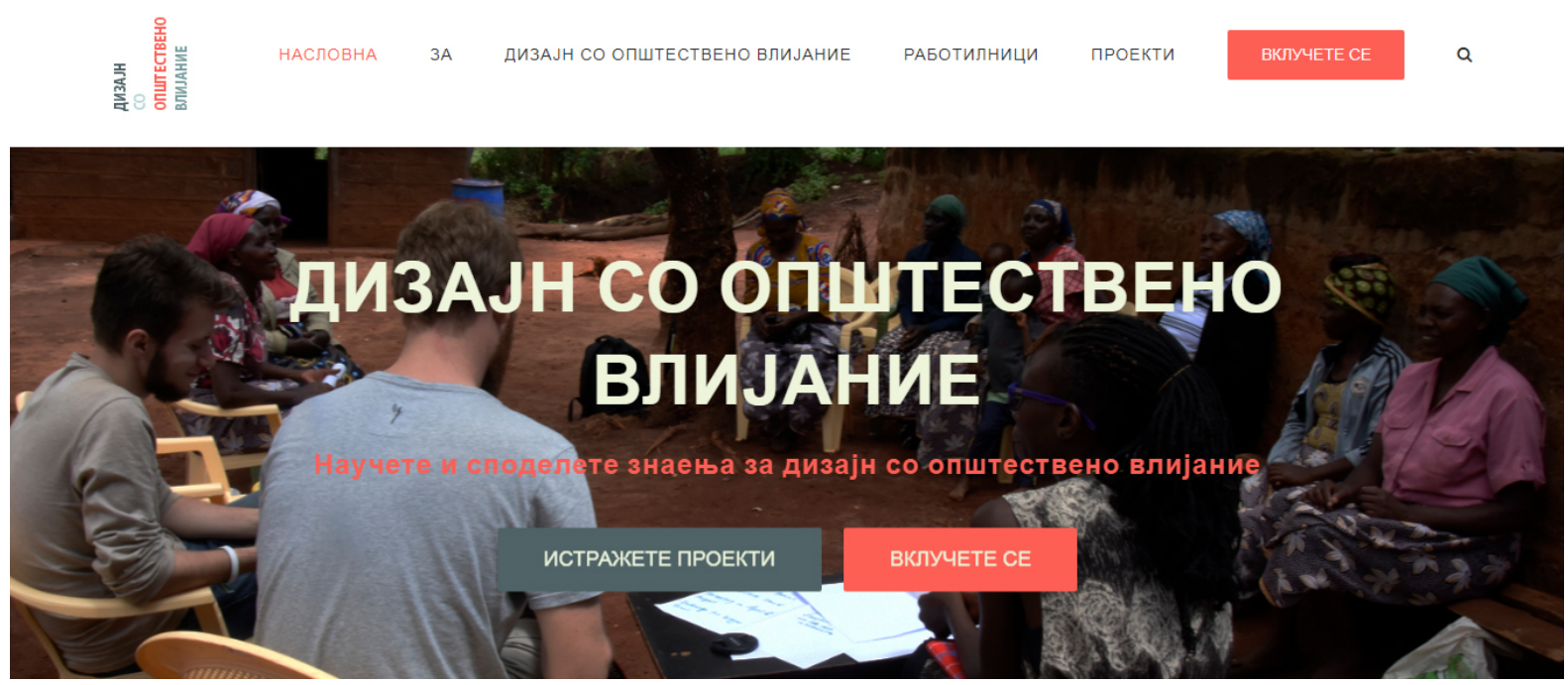

Сл. 108 Дел од насловната страница на веб платформата - секција со банер

Почнувајќи од насловната па се до страницата за внесување на податоци од страна на корисниците, веб платформата е дизајнирана на тој начин да го води погледот на корисниците, а со тоа и нивното внимание, од лево кон десно и одозгора па надолу.

Насловната страница започнува со „леплив“ хедер, кој е така наречен поради неговата функционалност - тој е постојано видлив без разлика каде се движи 
корисникот низ страниците на веб платформата. Најлево во полето на хедерот е поставено логото на веб платформата, кое истовремено има функција на линк до насловната страница. Десно од логото по хоризонтален редослед започнува главното мени кое се состои од линкови до следните страници: насловна, за, дизајн со општествено влијание, работилници, проекти и вклучете се. После главното мени, најдесно на хедерот, се наоѓa икона за пребарување на податоци на веб платформата. Со кликнување на иконата за пребарување на податоци се појавува мал прозорец со поле за внесување на податоците кои треба да се пребаруваат. Подолу од хедерот е вметнат интерактивен банер (Сл. 108), кој во ова сценарио постои со цел да ги привлече корисниците директно да превземат акција поврзана со двете главни функции на веб платформата - презентирање и прибирање на податоци за дизајн со општествено влијание.

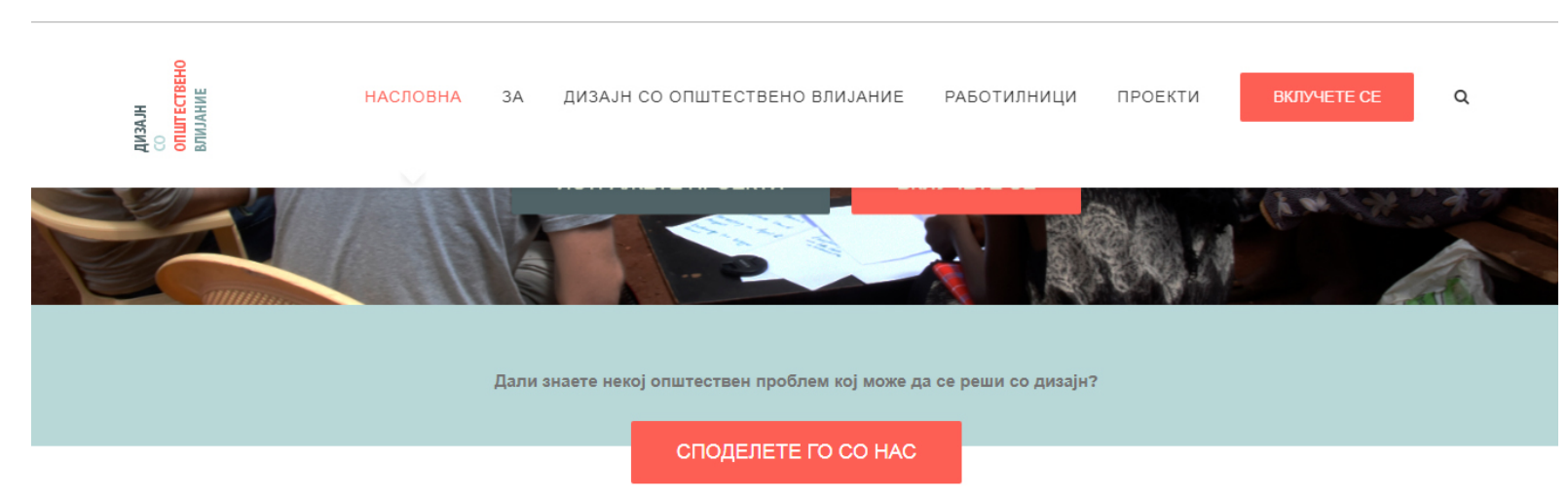

АКТУЕЛНИ ОПШТЕСТВЕНИ ПРОБЛЕМИ ВО МАКЕДОНИЈА

Сл. 109 Дел од насловната страница на веб платформата - секција со мал банер

Веднаш под банерот на насловната страница се наоѓа мал банер ( Сл. 109) кој има функција да го надополни примарниот. Доколку корисникот не превземал акција кога неговиот фокус бил кај примарниот банер, малиот банер, на сличен начин и со иста цел, повторно го примамува корисникот да превземе акција. 
Сл. 110 Дел од насловната страница на веб платформата - секција со содржински коцки

Ако корисникот продолжи со навигација под малиот банер на насловната страница ќе наиде на секција (Сл. 110) каде се претставени дел од актуелните општествени проблеми во Македонија. Оваа секција е составена од анимирани содржински коцки со текст и икона која се трансформира во друга боја кога ќе се помине со курсорот над неа.

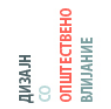

Сл. 111 Дел од насловната страница на веб платформата - секција со информативен текст

Како надополнување на секцијата со атуелните општествени проблеми во Македонија е креирана секција во форма на информативен текст (Сл. 111) кој содржи 
слогани што имаат за цел дополнително да ги привлечат и охрабрат корисниците да се вклучат во активности за дизајн со општествено влијание.
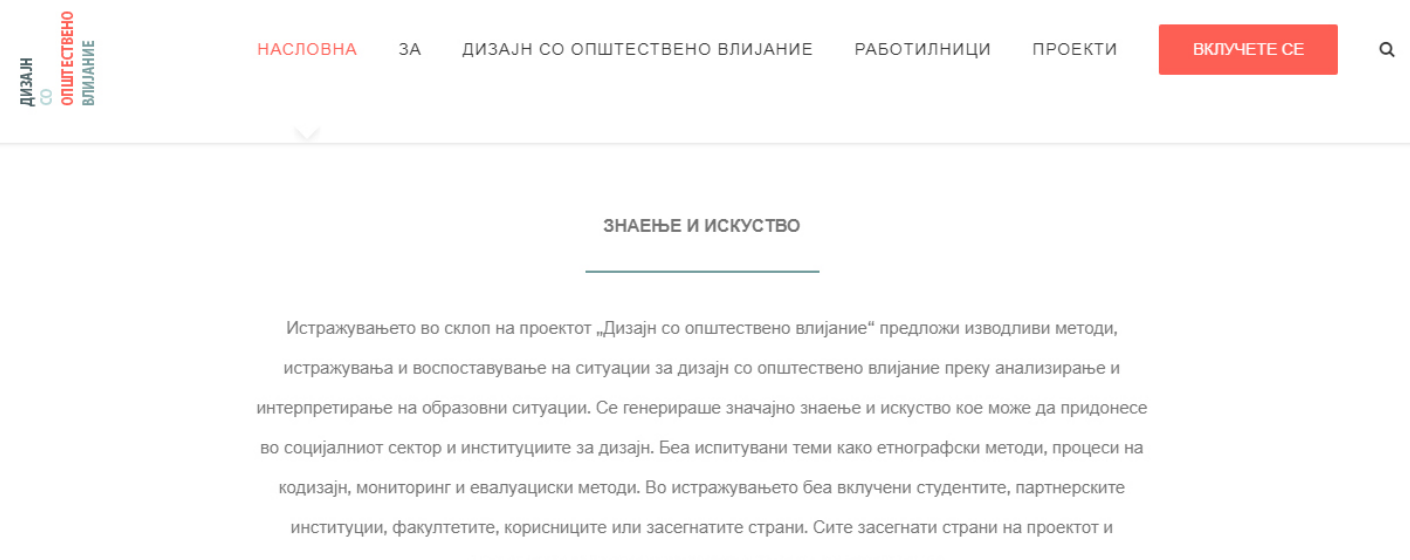

учесниците придонесоа за резултатите од истражувањето.

Сл. 112 Дел од насловната страница на веб платформата - секција со информативен текст

Наредната секција (Сл. 112) на насловната страница се состои од информативен текст кој има за цел да им овозможи краток преглед на корисниците за истражувањето од проектот „Дизајн со општествено влијание“.

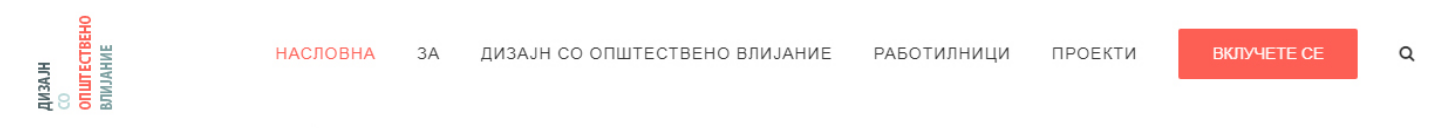

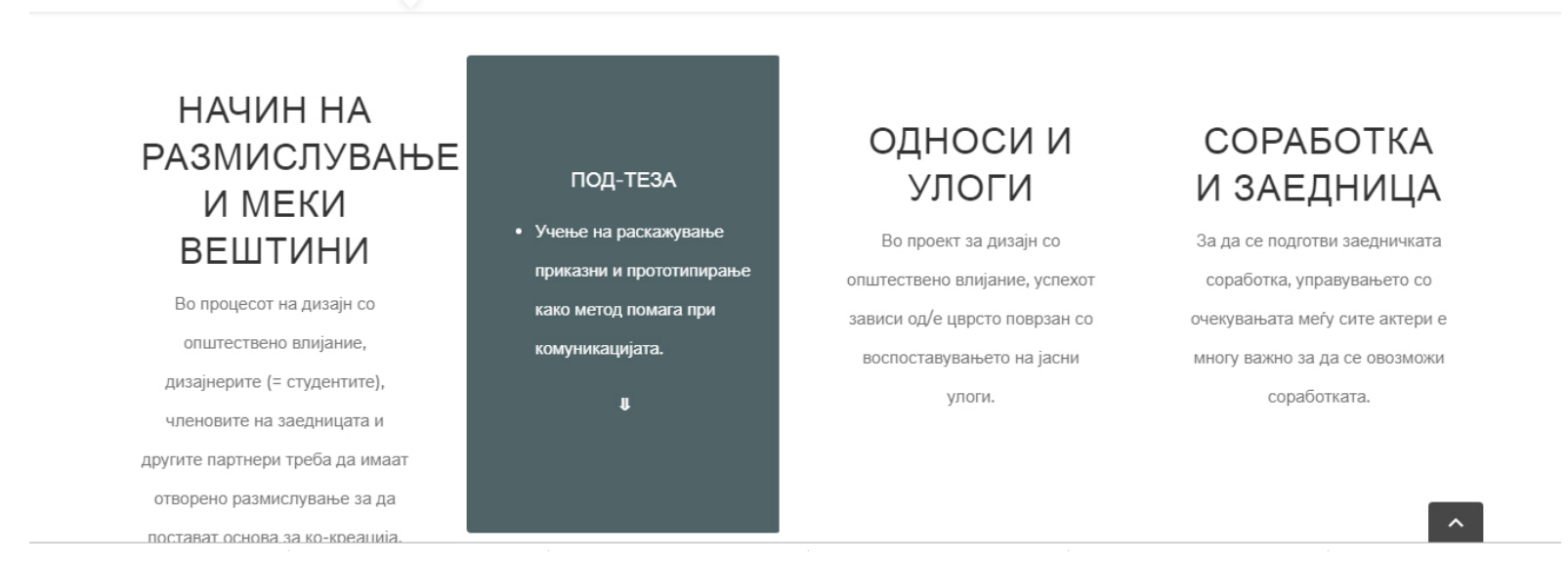

Сл. 113 Дел од насловната страница на веб платформата - секција со анимирани карти за текст

Под информативниот текст на насловната страна се наоѓa секција со анимирани карти (Сл. 113) во кои е вметнат текст со содржина од генерираните знаења и искуства 
со истражувањето во склоп на проектот „Дизајн со општествено влијание“. Кога корисникот поминува со курсорот од глувчето врз текстот, се активира анимацијата и картата се „свртува“ од задната страна каде има дополнителен текст кој се надоврзува на текстот од предната страна.

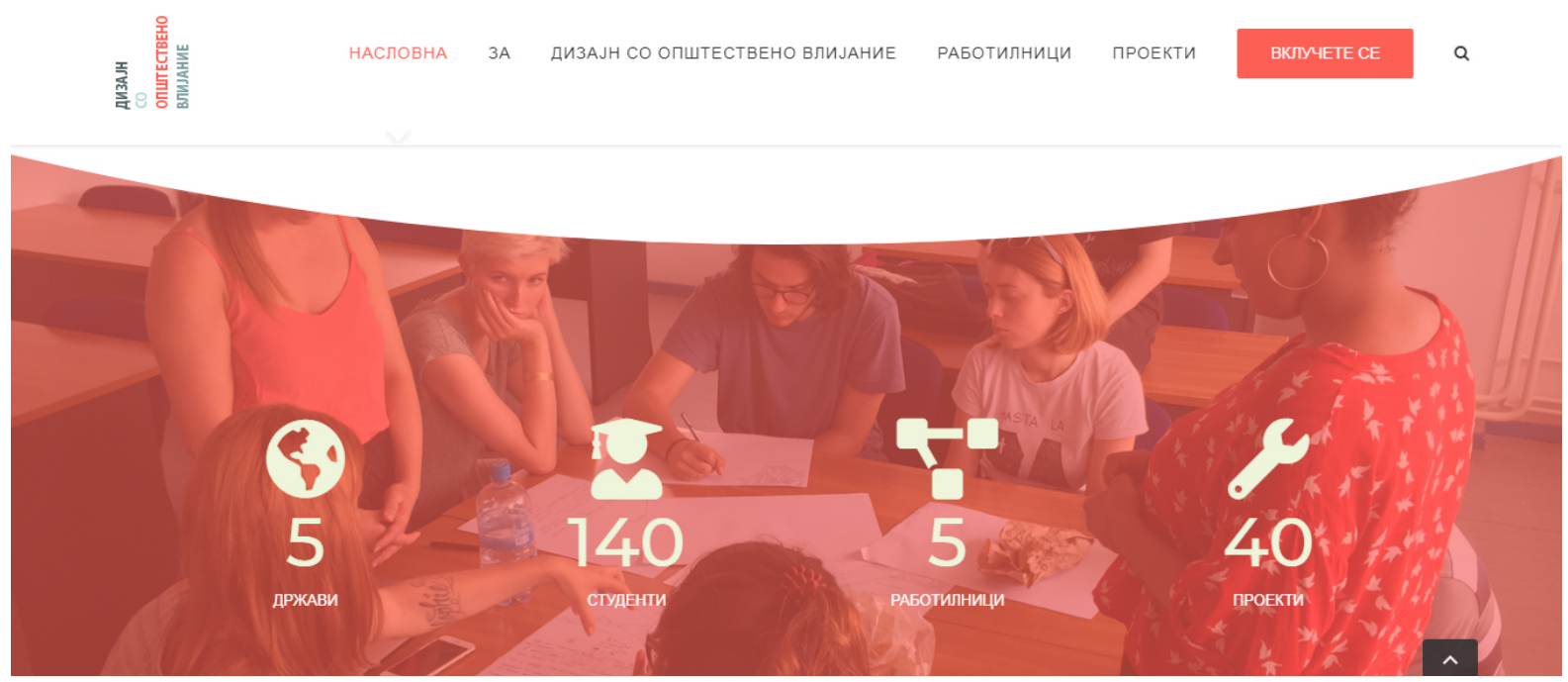

Сл. 114 Дел од насловната страница на веб платформата - секција со анимиран бројач

Наредната секција на насловната страница е анимиран бројач (Сл. 114) кој презентира квантитативни податоци за проектот „Дизајн со општествено влијание“. Во овој случај моментално има поставено бројачи со податоци за бројот на земји и студенти кои досега се вклучиле во проектот и бројот на реализирани работилници и проекти.

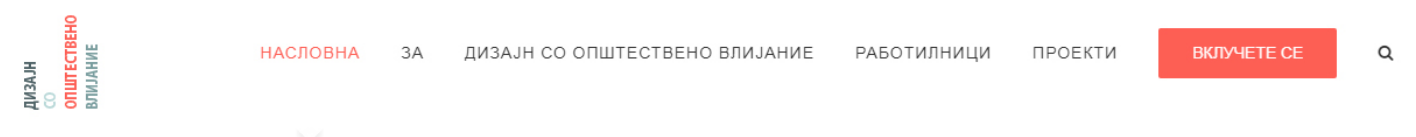

НАЈНОВИ РАБОТИЛНИЦИ
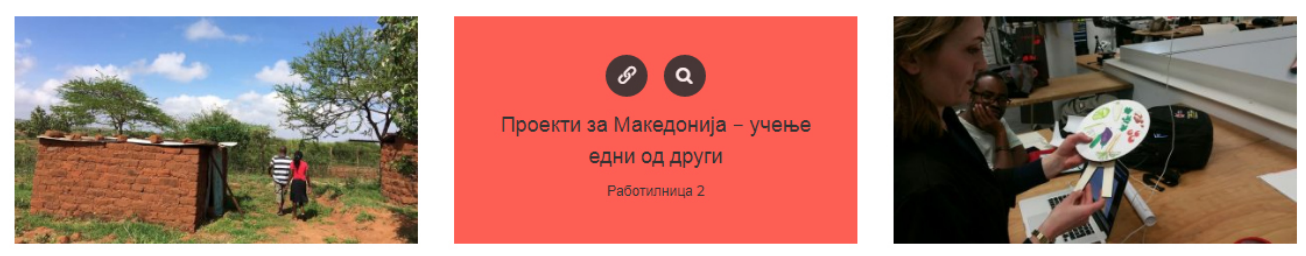

\section{BИДЕТЕ ГИ СИTЕ}

Сл. 115 Дел од насловната страница на веб платформата до секцијата за приказ на работилниците 
Една од најважните секции на насловната страница е таа која служи за краток преглед на реализираните работилници (Сл. 115). Корисникот од овде може директно да отвори некоја работилница, или пак да ги погледне сите со притискање на наменетото копче за тоа, без притоа да мора да ја отвори страницата за работилниците која е линкувана во главното мени.

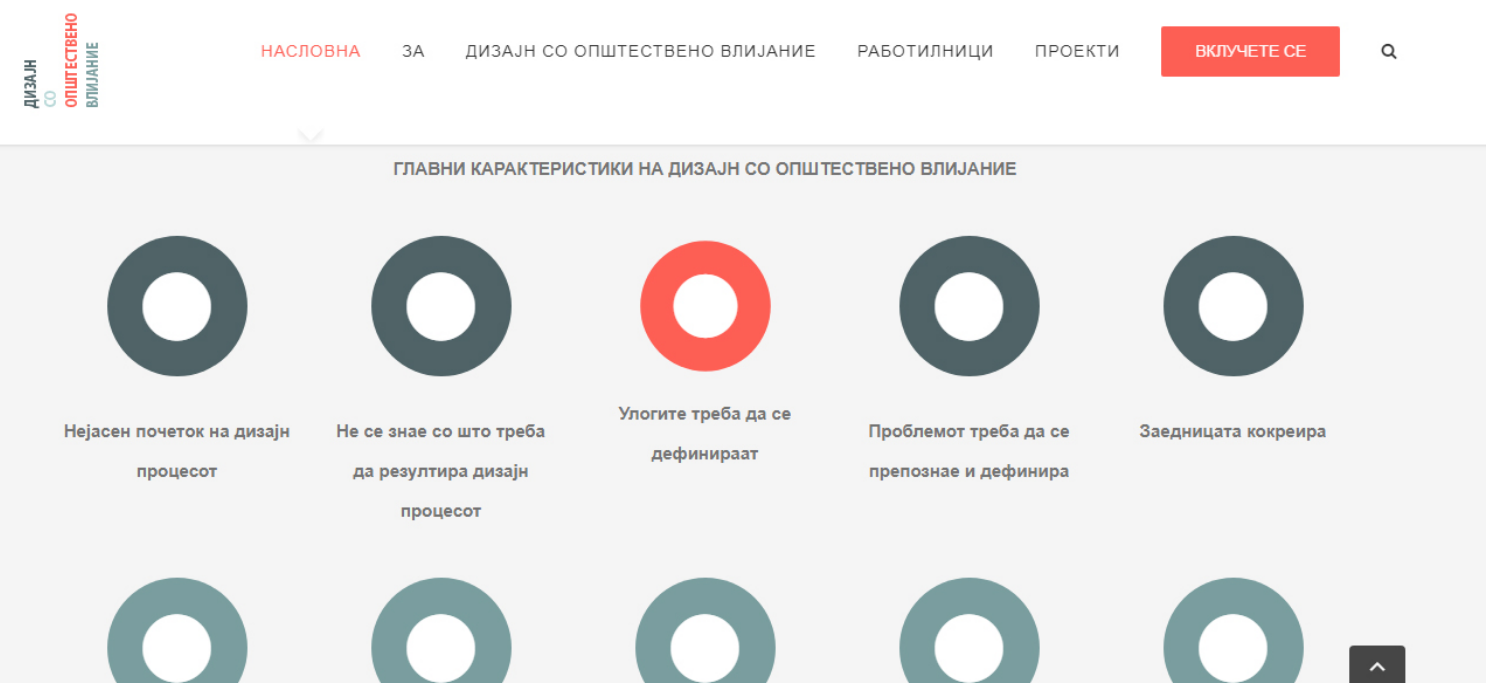

Сл. 116 Приказ на насловната страница на веб платформата до секцијата за содржински коцки

Наредно што се презентира на насловната страница се главните карактеристики на дизајнот со општествено влијание (Сл. 116). Тие се презентирани со анимирани содржински коцки кои содржат текст и икона која се трансформира во друга боја, со ефект на зрачење, кога ќе се помине со курсорот над неа.

\section{III

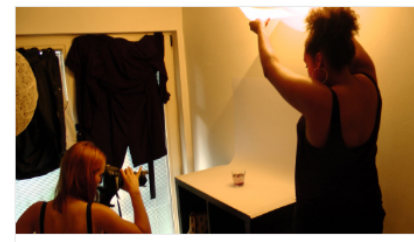

Брендирање на природна македонска храна March 5th, 2019

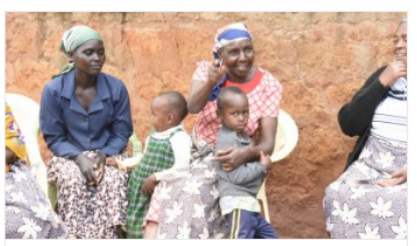

Ребека Муинди November 215t, 2018

Профил на фармерот Ребека е постар

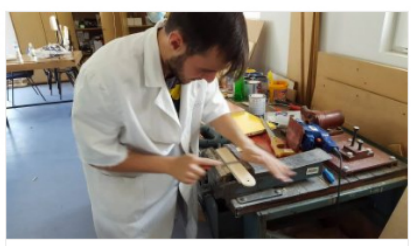

Нова интерпретација на македонската традиција November 15th, 2018

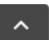

Сл. 117 Приказ на насловната страница на веб платформата до секцијата за приказ на проектите 
Покрај работилниците, простор на насловната страница имаат и проектите. Од оваа секција (Сл. 117) корисниците имаат директен пристап до проектите, без притоа да мора да пристапуваат до нив преку главното мени.

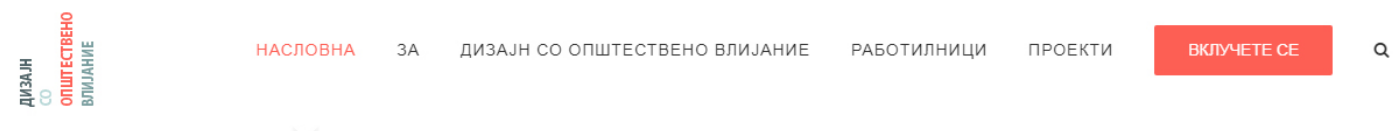

TAPTHEPИ

\section{STIFTUNG MERCATOR SCHWEIZ}
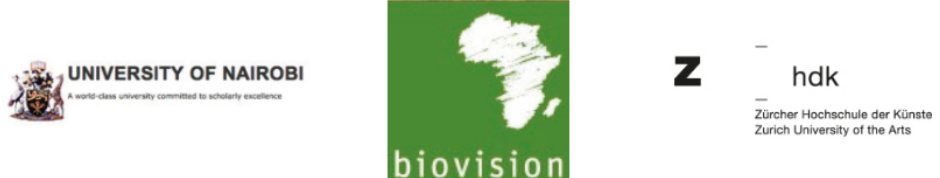

Сл. 118 Приказ на насловната страница на веб платформата до секцијата за приказ на партнери

Кон крајот на насловната страница, непосредно пред футерот, се наоѓа секција (Сл. 118) каде се поставени логоа од партнерските организации преку анимиран слајдер.
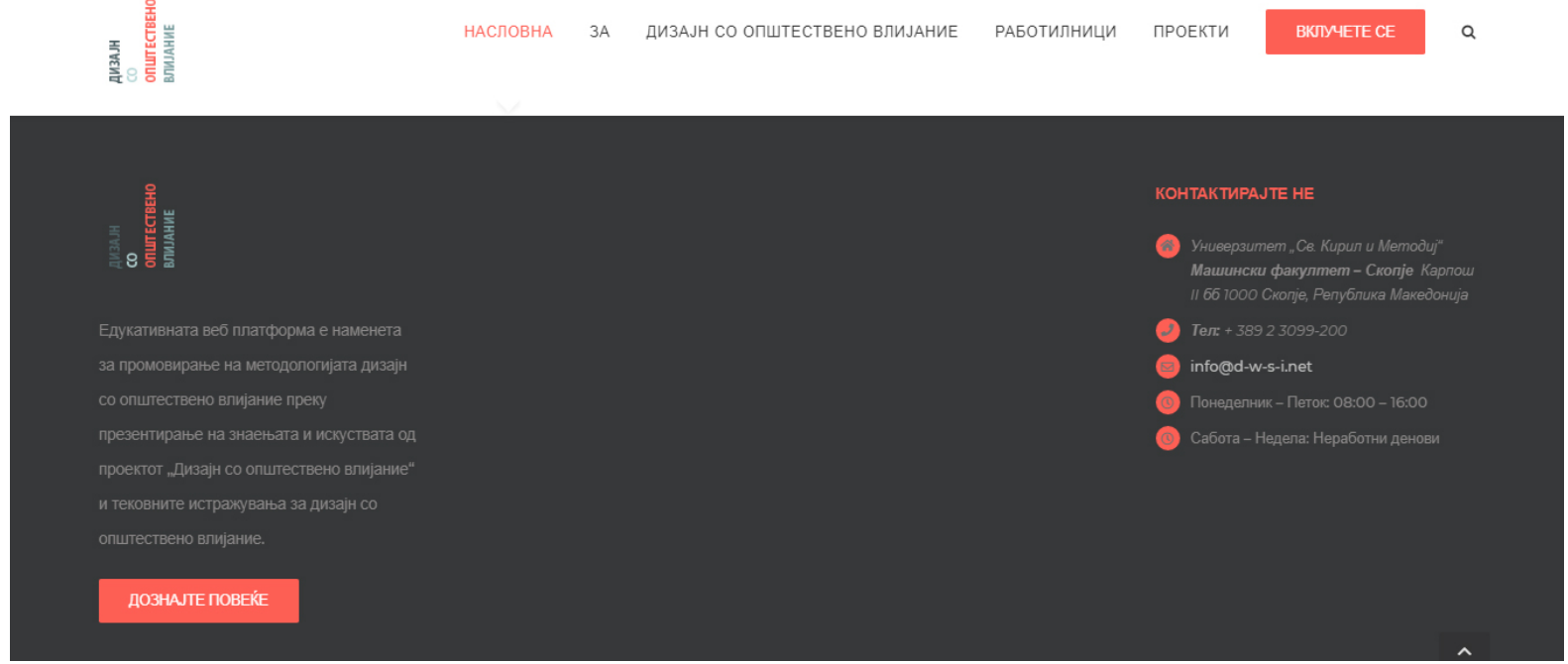

Сл. 119 Приказ на насловната страница на веб платформата до секцијата за футер 
Како и кај повеќето веб страници, најдолу се наоѓа футерот (Сл. 119). Во оваа секција се наоѓa логото, информативен текст за веб платформата, како и контакт информации.

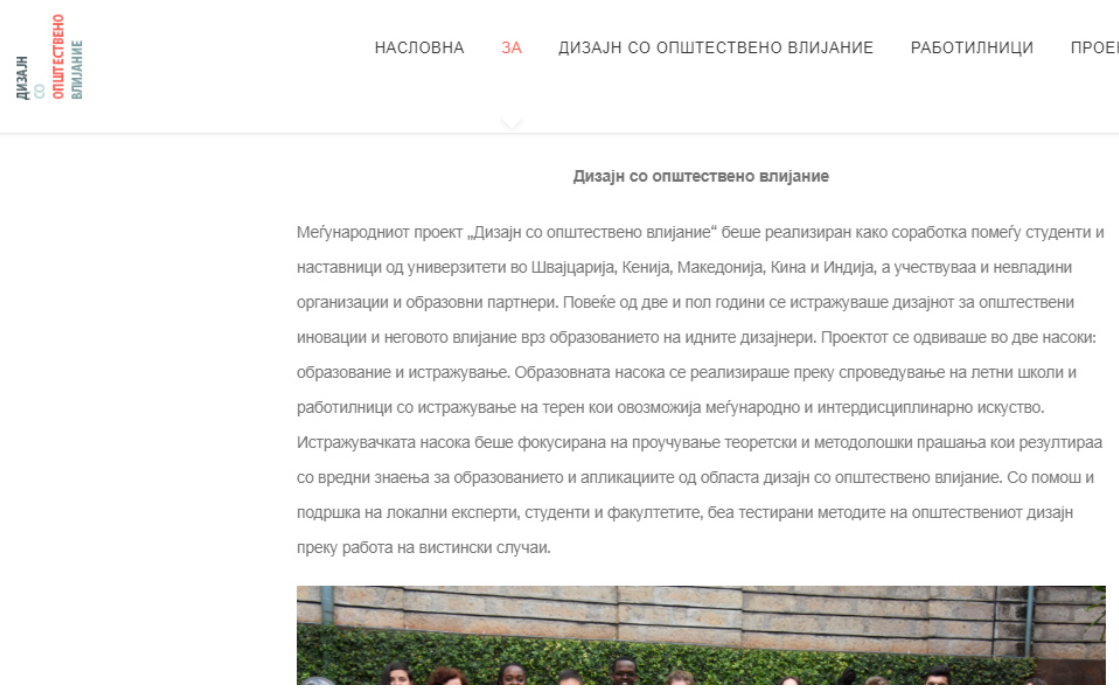

Сл. 120 Приказ на „за“ страницата на веб платформата

Страницата „за“ (Сл. 120) со пристап од главното мени служи за информирање на корисниците за проектот „Дизајн со општествено влијание“. За разлика од насловната страница, оваа страница е многу поедноставна.
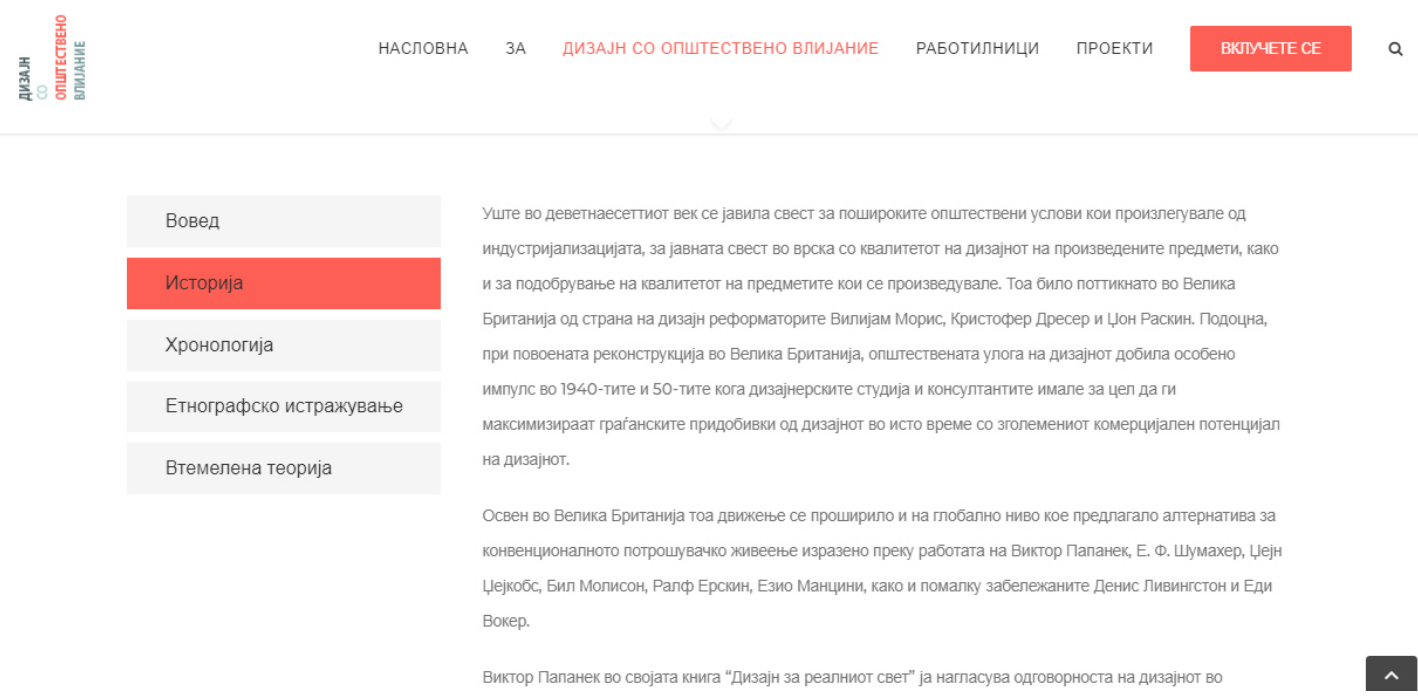

Сл. 121 Приказ на „дизајн со општествено влијание“ страницата на веб платформата 
Истражувањето за дизајн со општествено влијание се презентира на веб платформата во истоимена страница (Сл. 121). Покрај тоа овде се презентираат и истражувачките методи втемелена теорија и етнографско истражување. Поради обемниот материјал што се содржи во оваа страница, имаше потреба да се креира вертикално мени со улога да ја раздели содржината во повеќе делови, а со тоа да се подобри ергономијата.

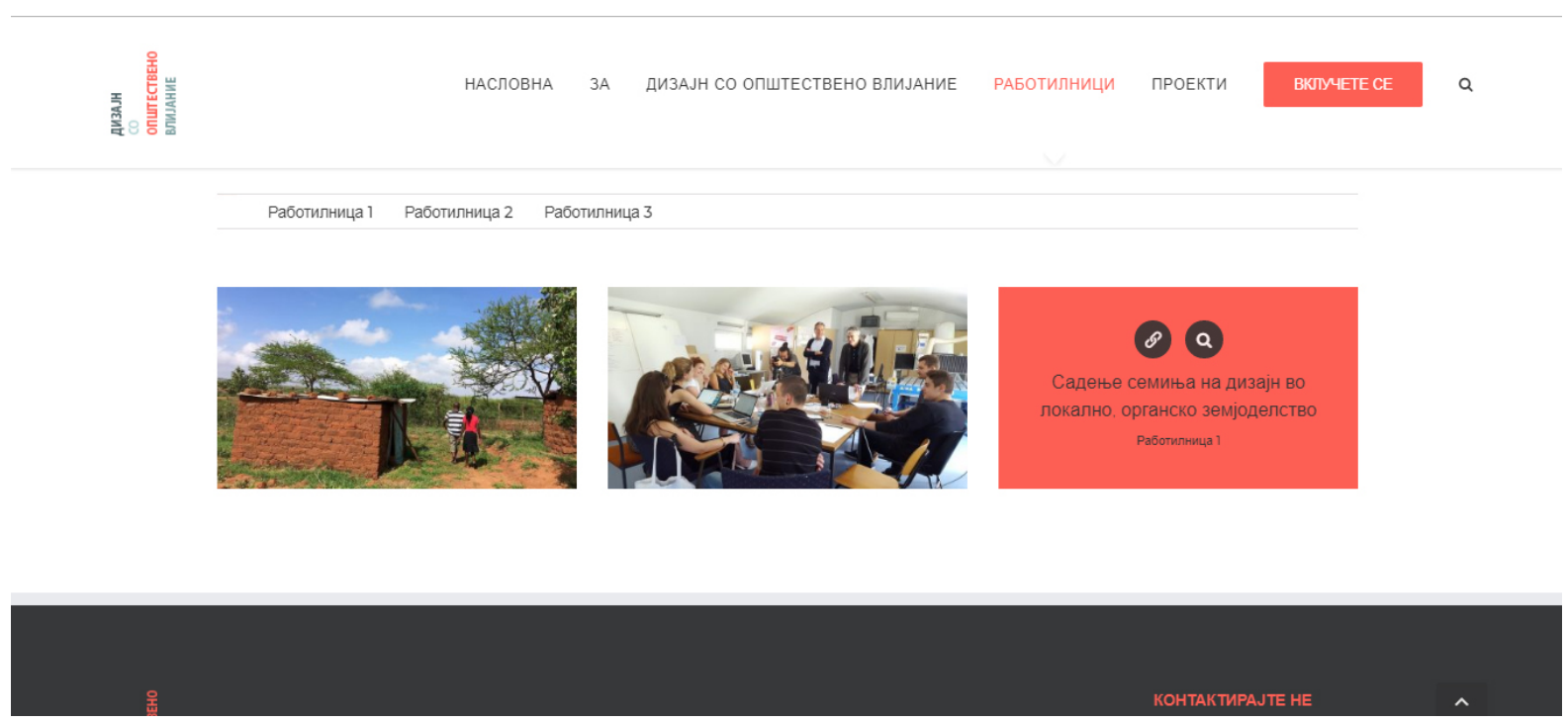

Сл. 122 Приказ на „работилници“ страницата на веб платформата

Следниот линк од главното мени е „работилници“ кој води кон страница во која се презентирани и филтрирани работилниците (Сл. 122). Корисниците од оваа страница можат да ги пребаруваат работилниците, а доколку сакаат детално да разгледат некоја (Сл. 124), потребно е да кликнат на сликата со која е прикажана работилницата. Со отварање на некоја од работилниците, се отвара нова страница каде што има презентирано информации за само една работилница (Сл. 123). 


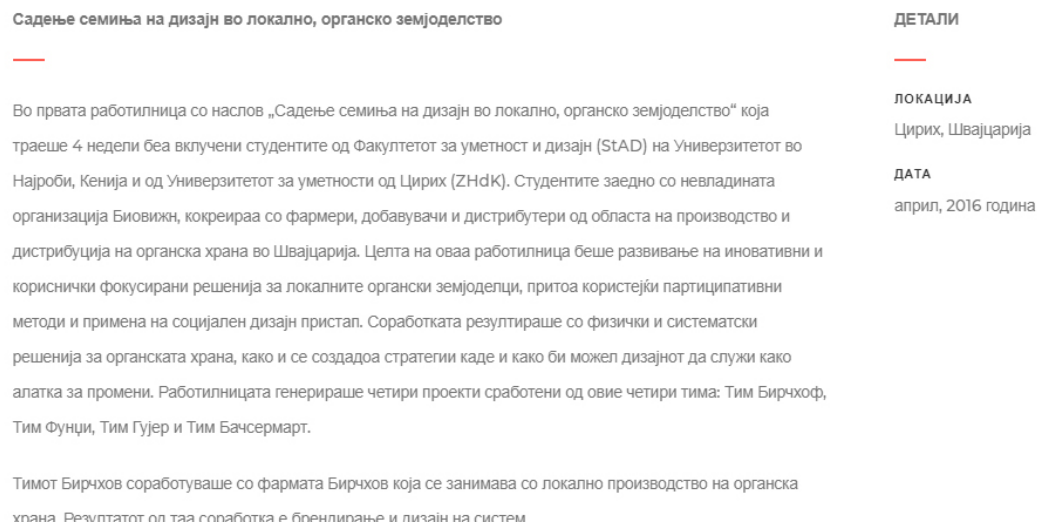

\section{Сл. 123 Приказ на пост од работилница на веб платформата}

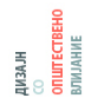

ГАЛЕРИJA
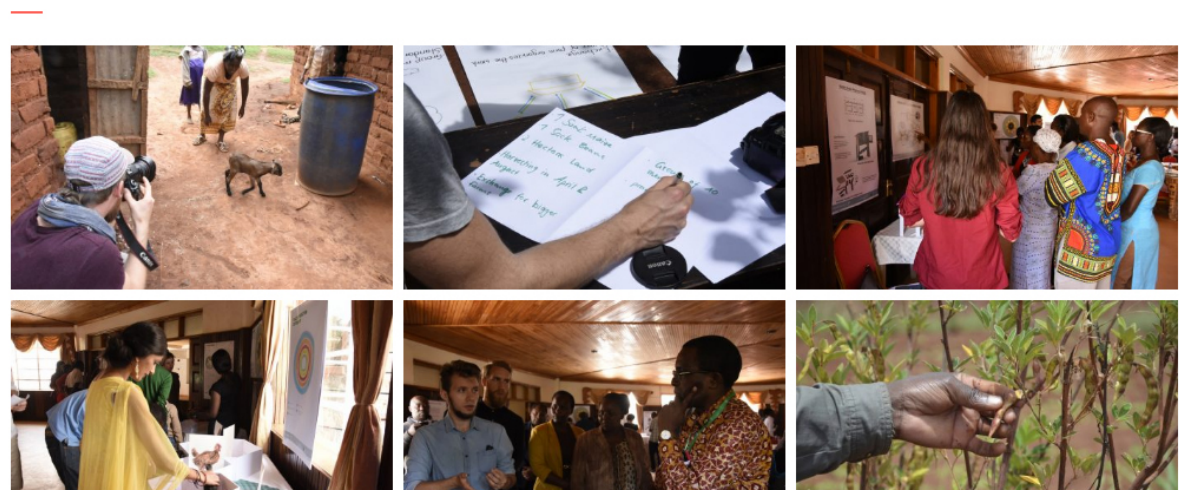

Сл. 124 Приказ на галерија од работилница на веб платформата 

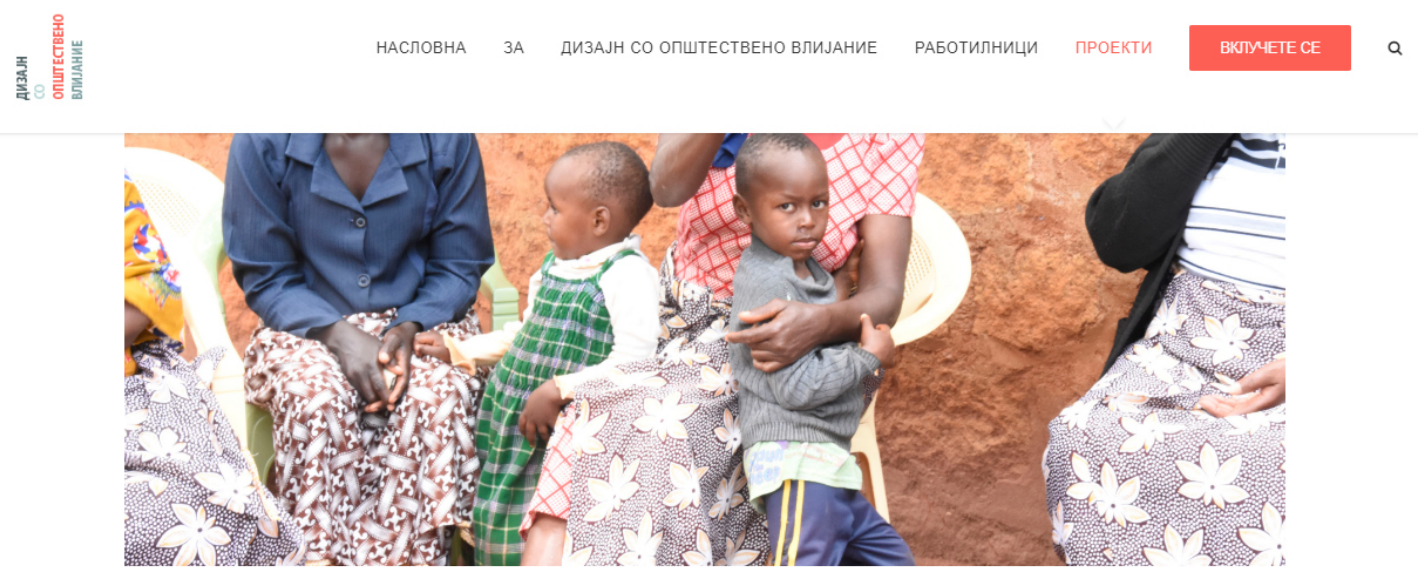

Ребека Муинди

Сл. 125 Приказ на „проекти“ страницата на веб платформата

Страницата каде што се презентирани проектите (Сл. 125) е многу слична со страницата каде што се презентирани работилниците. Разликата е во тоа што овде се презентирани проектите (Сл. 126, Сл. 127) кои се реализирани во склоп на тие работилници, како и начинот на кој се подредени постовите соодветно во страниците. Работилниците се распоредени мрежно, додека проектите се распоредени хронолошки во една колона.
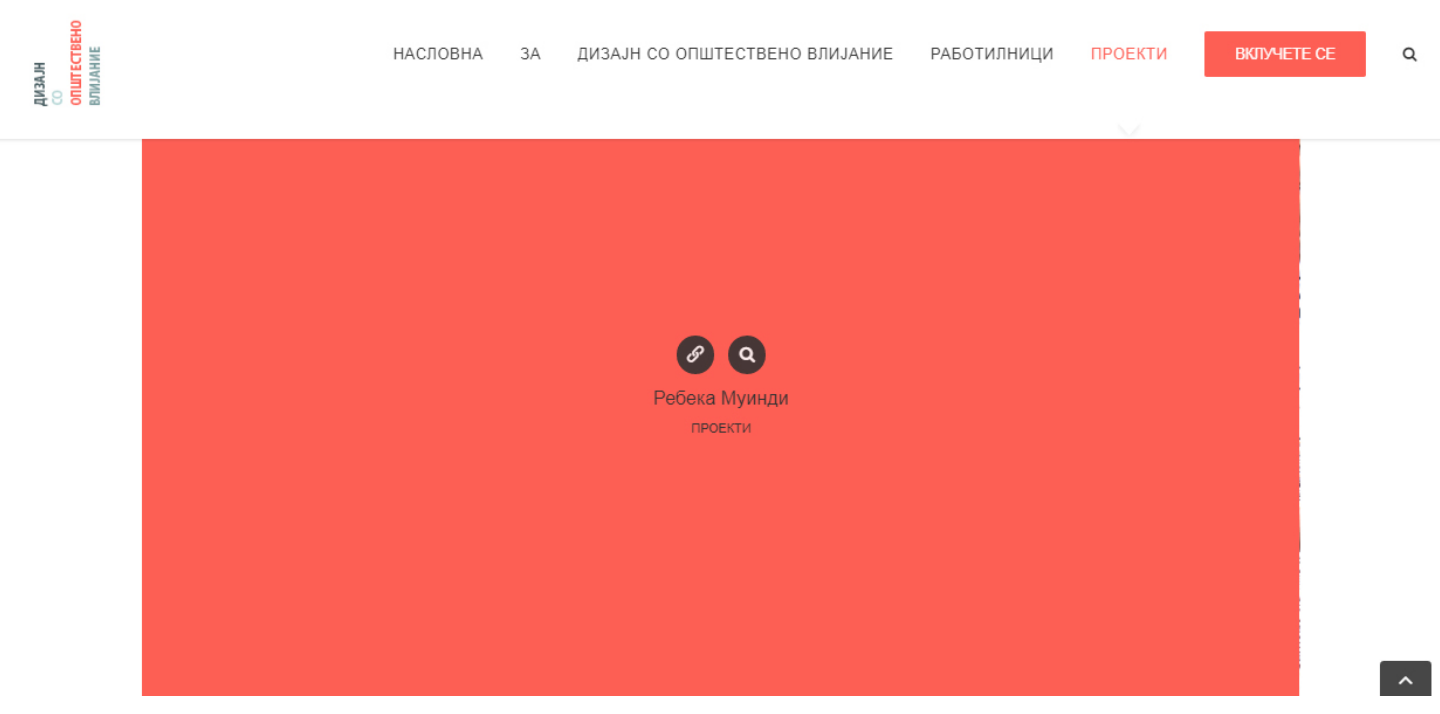

Сл. 126 Приказ на одбележан пост од проект на веб платформата 


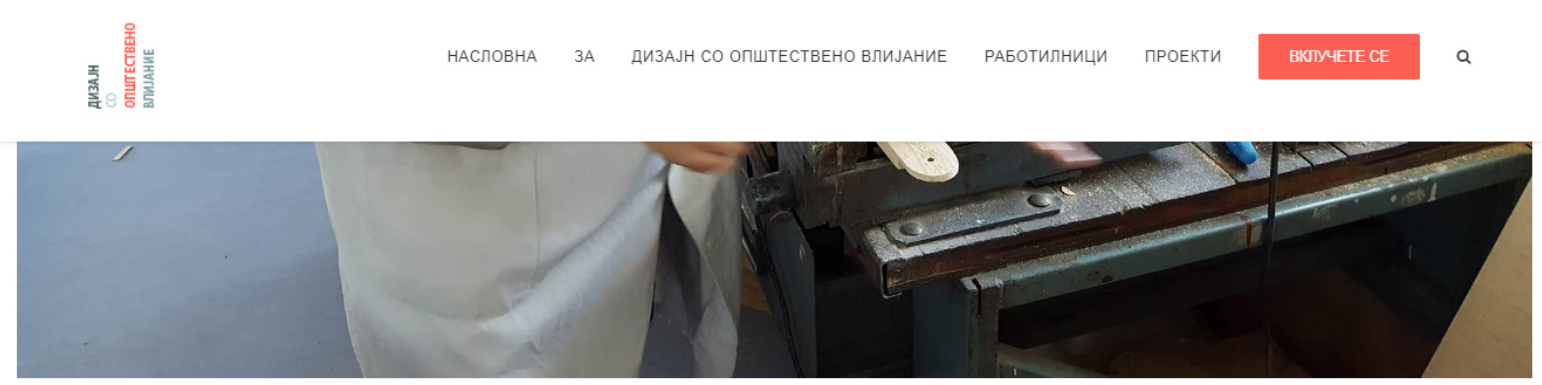

Нова интерпретација на македонската традиција

Наслов на бизнис проблемот предложен од Свисконтакт:

- Економско зајакнување на жените од Дебар и с. Броштица, Дебарско

Заедници поврзани со бизнис проблемот:

- „Радика Де“ - женска асоцијација од Дебар

- Регионален Бизнис Центар - Скопіе

Сл. 127 Приказ на пост од проект на веб платформата
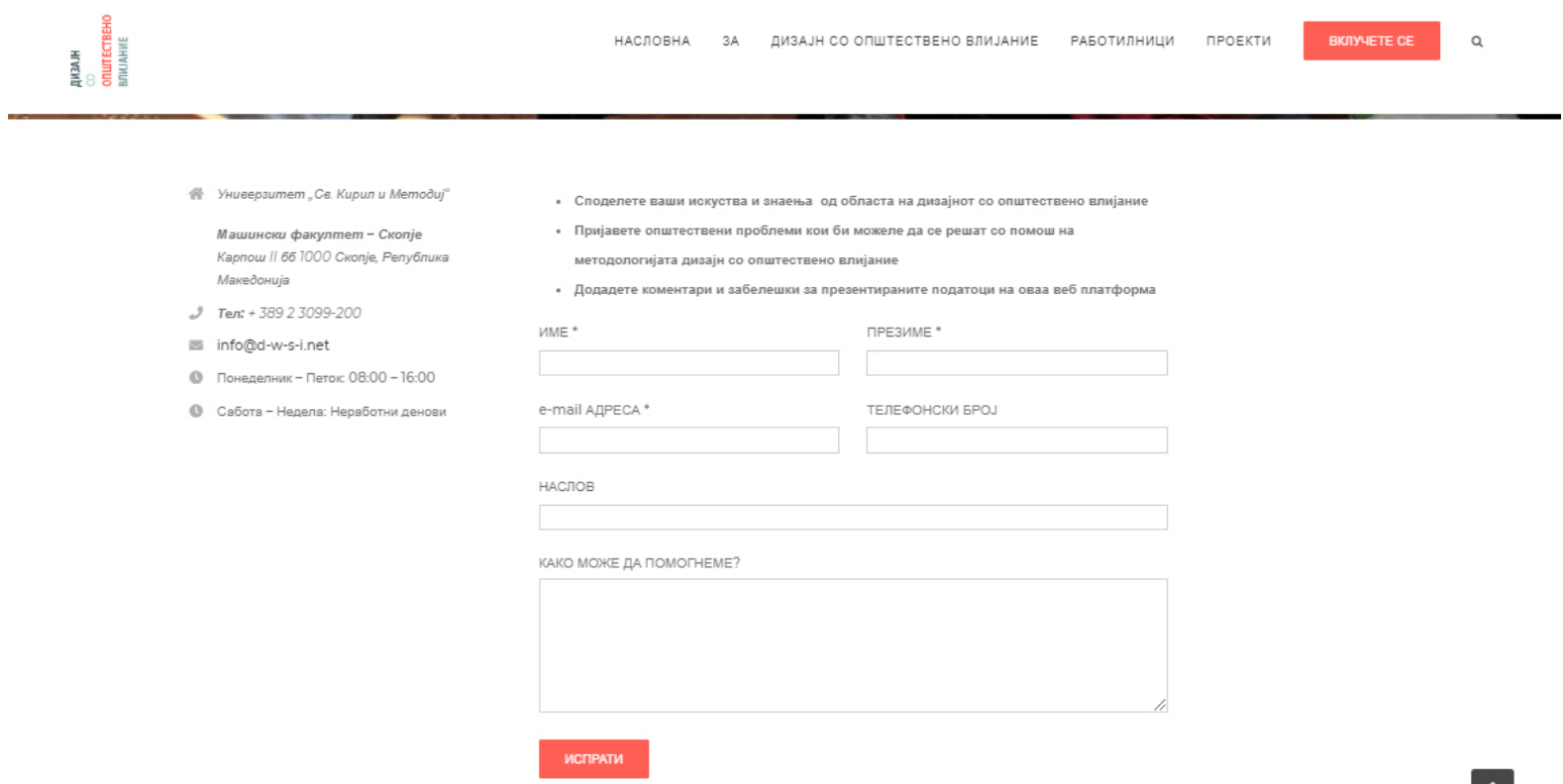

Сл. 128 Приказ на „вклучете се“ страницата на веб платформата

Последната страница „вклучи се“ (Сл. 128) од главното мени, која всушност е и најважна, служи за внес на податоци од страна на корисниците и има за цел размена на искуства и знаења помеѓу корисниците кои ги искусиле придобивките на применетите методи на дизајнирање со општествено влијание. Преку оваа страница исто така може да се пријавуваат социјални проблеми од страна на корисници кои би можеле да се решат со помош на методологијата дизајн со општествено влијание. Покрај другото, од оваа страница корисниците може да испраќаат коментари и забелешки за презентираните податоци на оваа едукативна веб платформа. 


\section{6 Евалуација на веб платформата}

По изработката на концептот на едукативната веб платформа за промовирање на методологијата дизајн со општествено влијание, беше неопходно истата да се евалуира и провери дали ги исполнува претходно дефинираните барања.

Изработената веб платформа преку страниците насловна, за, дизајн со општествено влијание, работилници и проекти, јасно ги презентира податоците на корисниците. Насловната страница го води корисникот низ веб платформата и воедно прикажува делови од сите содржини кои се наоѓаат низ другите страници. Страницата „за“ го опишува проектот „Дизајн со општествено влијание“. Во страницата „дизајн со општествено влијание“ е презентирано истражувањето за дизајнот со општествено влијание, етнографско истражување, втемелена теорија, како и извлечените знаења и заклучоци. Работилниците се презентирани соодветно во страницата „работилници“, а проектите во страницата „проекти“. Ова значи дека изработениот концепт го задоволува барањето да ги презентира наведените податоци на корисниците.

Последната страница од главното мени „вклучи се“, го задоволува барањето да се овозможи внесување на податоци од страна на корисниците. Страницата е изработена со цел да има можност за пријавување социјални проблеми, да се испраќаат коментари и забелешки за презентираниот материјал на веб платформата, а корисниците да разменуваат знаења и искуства за дизајнот со општествено влијание. Веб платформата е дизајнирана да биде слободна за користење, овозможено е секој кој има интерес за дизајн со општествено влијание слободно да превзема и да внесува податоци.

Од горенаведеното може да се заклучи дека изработениот концепт на веб платформа за промовирање на методологијата дизајн со општествено влијание, комплетно ги задоволува претходно дефинираните барања. 


\section{9. Заклучок}

Истражувањето презентирано во овој магистерски труд е резултат на мојата несекојдневна можност да бидам директен учесник во меѓународниот проект „Дизајн со општествено влијание“. Чувствував обврска и морална одговорност да ги систематизирам, анализирам и средам сите знаења и впечатоци стекнати преку овој проект, со цел да останат документирани за истражувачката работа на идните генерации студенти и професионалци од областа на дизајнот.

Особена чест ми претставува фактот што како член на истражувачкиот тим не само што стекнав големи искуства во примена на истражувачки методи во областа на дизајнот, туку дадов и директен придонес во развојот на методологијата дизајн со општествено влијание.

Моја најголема обврска кон проектот е промовирање на методологијата дизајн со општествено влијание на нашите простори. Сметам дека имам големи шанси да успеам во таа намера преку креирањето на веб порталот, презентиран во овој магистерски труд. Спроведената онлајн анкета покажа дека овој веб портал има потенцијал да ги мобилизира заедниците, невладините организации и дизајн тимовите на општествени промени преку дизајн техники и размислување.

Методологијата дизајн со општествено влијание има голем потенцијал за примена во општества како што е нашето, каде постојат многу предизвици за изнаоѓање решенија за бројните проблеми на разни социјални групи и заедници. Од друга страна, неопходно е подигање на свеста на сите професионалци во сите области на дизајнот дека нивното знаење и познавање на креативните техники на работа што ги користат, можат да дадат голем придонес во решавањето на општествени проблеми. Поттикнувањето на заедниците да ги презентираат своите проблеми, на дизајнерите да ги нудат своите знаења и спремноста за ко-креирање со членови на заедниците, како и мобилизацијата на невладините организации да се вклучат во посредување преку препознавање и поврзување на заедниците и дизајн тимовите се главните очекувања за начинот на кој овој веб портал би станал поттикнувач на општествени промени со помош на дизајн размислување. 


\section{Користена литература}

1. Armstrong, L., Bailey, J., Julier, G. and Kimbell, L., 2014. Social design futures: HEI research and the AHRC. University of Brighton, 2(1-4), 17-27.

2. Choi, Y., 2014. Measuring social values of design in the commercial sector. Brunel University London, 16-18.

3. Baek, J.S., Kim, S., Pahk, Y., 2016. A Sociotechnical Framework For the Design of Collaborative Services: Diagnosis and Conceptualisation. Proceedings of DRS 2016, Design Research Society 50th Anniversary Conference. Brighton, UK, 27-30 June 2016, 1-2.

4. Bason, C., 2013. "Discovering co-production by design", in Public \& Collaborative: Exploring the intersection of design social innovation and public policy. New York: Parsons DESIS Lab, 2(2), 3.

5. Ehn, P., 2008, October. Participation in design things. In Proceedings of the tenth anniversary conference on participatory design 2008 (pp. 92-101). Indiana University, 4(1), 2-3.

6. Woodcraft, S., Hackett, T. and Caistor-Arendar, L., 2011. Design for social sustainability: A framework for creating thriving new communities. Future Communities, 3, 15-16.

7. IDEO, 2008. Design for Social Impact: How-to Guide, The Rockefeller Foundation, 7.

8. Manzini, E. and Coad, R., 2015. Design, when everybody designs: An introduction to design for social innovation. MIT press, 1(3), 55-74.

9. Cooper-Hewitt, 2013. Design and Social Impact: A cross-sectional agenda for design education, research, and practice, The Smithsonian's Cooper-Hewitt, National Design Museum, in conjunction with the National Endowment for the Arts and The Lemelson Foundation, 3(1-2),32-34.

10. Bergvall-Kåreborn, B. and Ståhlbrost, A., 2008, October. Participatory design: one step back or two steps forward?. In Proceedings of the tenth anniversary conference on participatory design 2008 (pp. 102-111). Indiana University, 3(1), 2-3.

11. Hillgren, P.A., Seravalli, A. and Emilson, A., 2011. Prototyping and infrastructuring in design for social innovation. CoDesign, 7(3-4), pp.169-183, 2(1), 172-173.

12. Mulgan, G., Tucker, S., Ali, R. and Sanders, B., 2007. Social innovation: what it is, why it matters and how it can be accelerated. Skoll Centre for Social Entrepreneurship, 3(1),8-9.

13. Sanders, E.B.N. and Stappers, P.J., 2008. Co-creation and the new landscapes of design. Co-design, 4(1), pp.5-18, 1, 1-3.

14. Lee, Y.C. and Ho, D.K., 2013. From Bauhaus to DESIS: exploring solution-focused methodology for social design education.

15. Ehn, P., Nilsson, E.M. and Topgaard, R., 2014. Making futures: Marginal notes on innovation, design, and democracy. MIT Press. 
16. Papanek, V. and Fuller, R.B., 1972. Design for the real world. London: Thames and Hudson.

17. Akama, Y., 2014, Attuning to Ma (between-ness) in designing. Proceedings of the 13th Participatory Design Conference: Short Papers, Industry Cases, Workshop Descriptions, Doctoral Consortium papers, and Keynote abstracts-Volume 2 (pp. 2124). ACM.

18. Bratteteig, T., Bødker, K., Dittrich, Y., Mogensen, P.H. and Simonsen, J., 2012. Organising principles and general guidelines for Participatory Design Projects. Routledge Handbook of Participatory Design.

19. Pedersen, J., 2007. Protocols of research and design. Ph. D. thesis. Copenhagen: IT University

20. Von Hippel, E., 2005. Democratizing innovation. MIT press.

21. Buur, J., Fraser, E., Oinonen, S. and Rolfstam, M., 2010, November. Ethnographic video as design specs. Proceedings of the 22 nd Conference of the Computer-Human Interaction Special Interest Group of Australia on Computer-Human Interaction (pp. 49-56). ACM.

22. Whitehead, T.L., 2005. Basic classical ethnographic research methods. Ethnographically Informed community and cultural assessment research systems.

23. Pitt-Catsouphes, M., Kossek, E.E. and Sweet, S., 2015. The work and family handbook: Multi-disciplinary perspectives and approaches. Routledge.

24. Corbin, J. and Strauss, A., 1990. Grounded theory research: Procedures, canons and evaluative criteria. ZeitschriftfürSoziologie, 19(6), pp.418-427.

25. Charmaz, K. and Belgrave, L.L., 2007. Grounded theory. The Blackwell encyclopedia of sociology.

26. http://designwithsocialimpact.net 